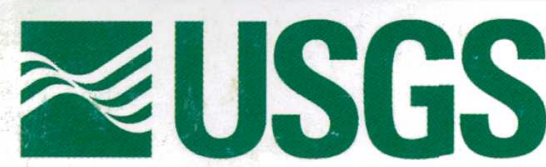

science for a changing world

In cooperation with the

MONTANA DEPARTMENT OF NATURAL RESOURCES AND CONSERVATION and LEWIS AND CLARK COUNTY

\title{
Streamflow and Water-Quality Characteristics in the Upper Tenmile Creek Watershed, Lewis and Clark County, West-Central Montana
}

Water-Resources Investigations Report 00-4129

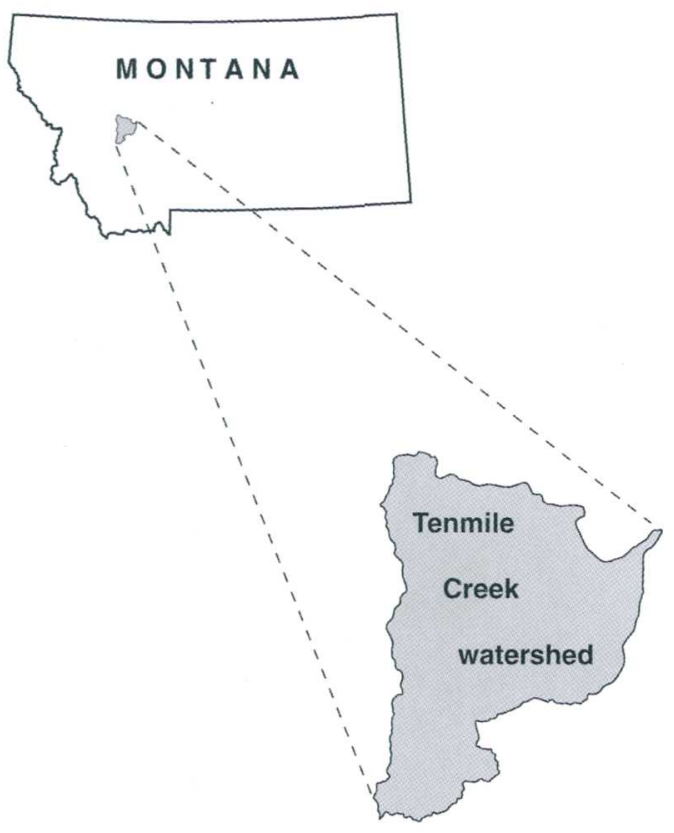

U.S. Department of the Interior U.S. Geological Survey

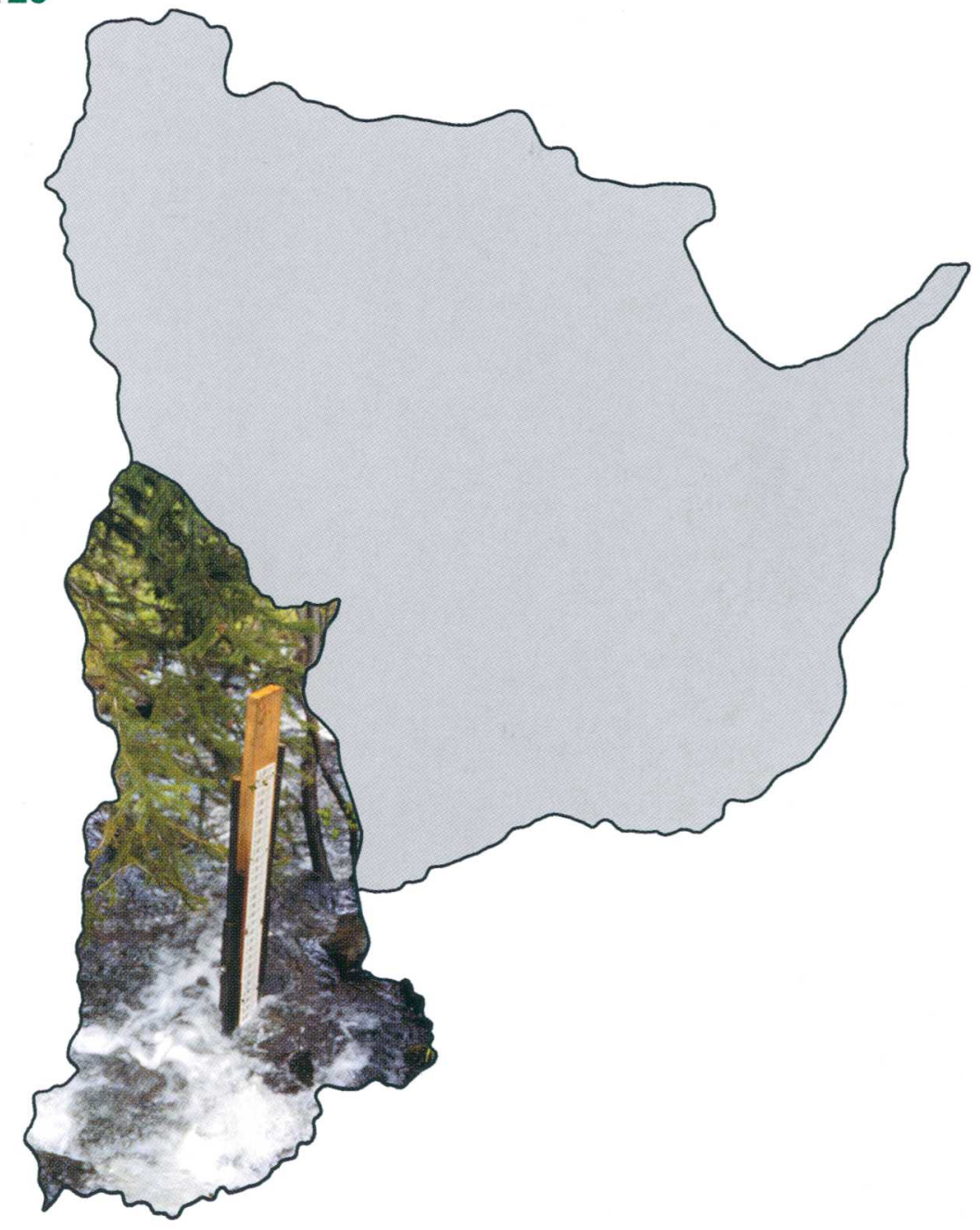


COVER: Staff gage on Ruby Creek at mouth near Rimini, Montana. 
U.S. Department of the Interior

U.S. Geological Survey

Streamflow and Water-Quality Characteristics in the Upper Tenmile Creek Watershed, Lewis and Clark County, West-Central Montana

\section{By Charles Parrett and Patricia S. Hettinger}

Water-Resources Investigations Report 00-4129

In cooperation with the MONTANA DEPARTMENT OF NATURAL RESOURCES AND CONSERVATION and LEWIS AND CLARK COUNTY 


\title{
U.S. Department of the Interior
}

BRUCE BABBITT, Secretary

\section{U.S. Geological Survey}

Charles G. Groat, Director

Any use of trade, product, or firm name in this publication is for descriptive purposes only and does not imply endorsement by the U.S. Government

Helena, Montana

September 2000

For additional information write to:

\section{District Chief}

U.S. Geological Survey

3162 Bozeman Avenue

Helena, MT 59601-6456

Copies of this report may be purchased from:

\author{
U.S. Geological Survey \\ Branch of Information Services \\ Box 25286 \\ Denver, CO 80225-0286
}




\section{CONTENTS}

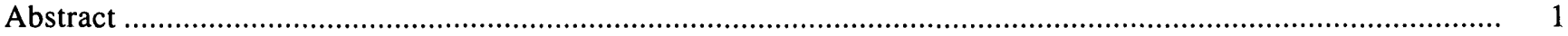

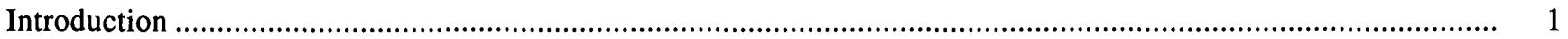

Purpose and scope

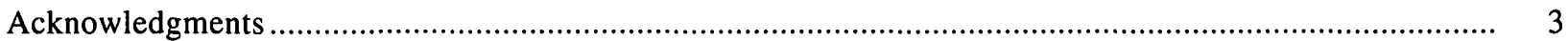

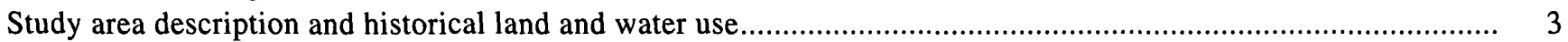

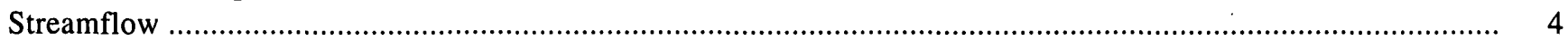

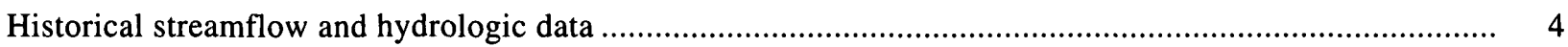

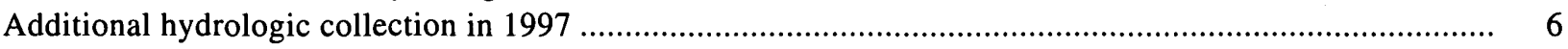

Techniques for estimation of long-term monthly and daily discharge ............................................... 6

Estimation of long-term monthly natural flows for Tenmile Creek near Rimini ................................ 8

Estimation of daily natural discharge for May-October 1997 for Tenmile Creek near Rimini ............. 9

Estimation of long-term monthly natural discharge for selected sites .......................................... 11

Reliability of long-term monthly discharge estimates ................................................................... 16

Determination of gaining and losing stream reaches on Tenmile Creek ................................................... 17

Water-quality

Strategy for sample collection and analysis ....................................................................................... 21

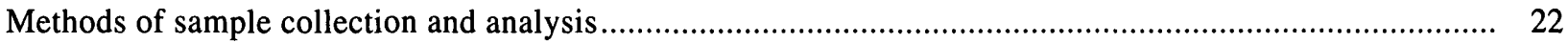

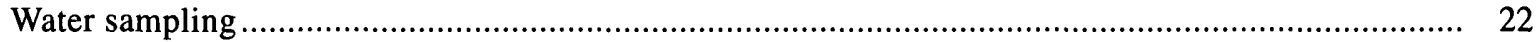

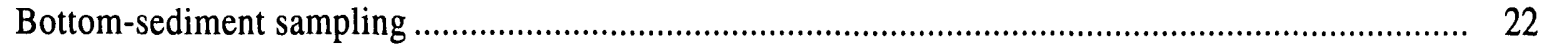

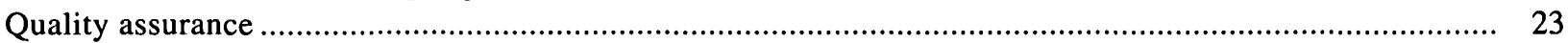

Sampling sites and potential sources of water-quality degradation ................................................... 24

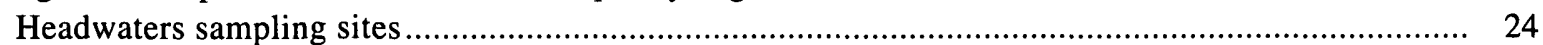

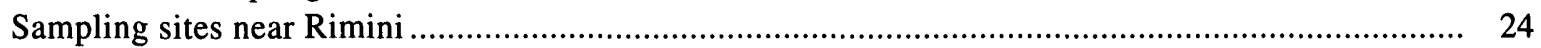

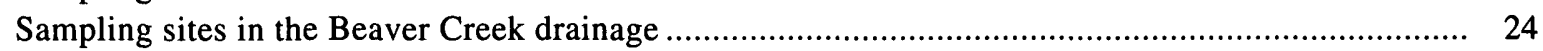

Sampling sites between Rimini and the Tenmile Water Treatment Plant ...................................... 25

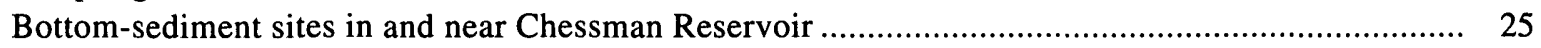

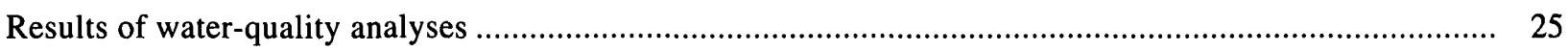

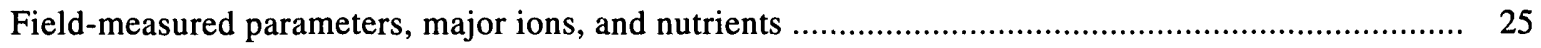

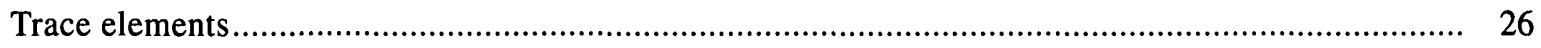

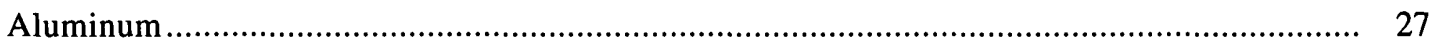

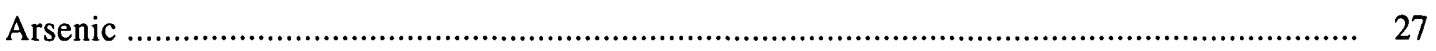

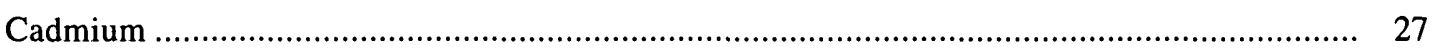

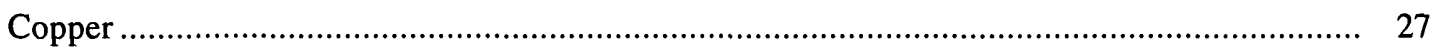

Iron

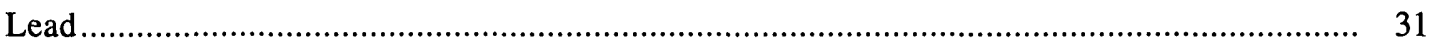

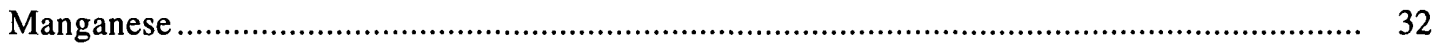

Chromium, mercury, nickel, selenium, and silver ....................................................... 32

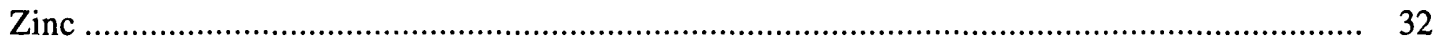

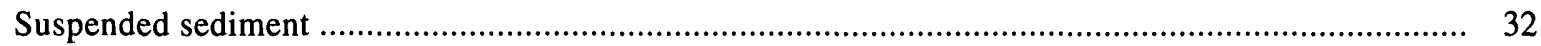

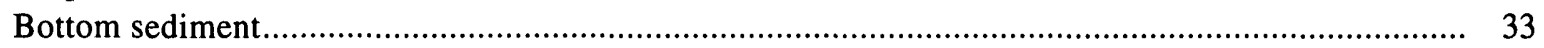

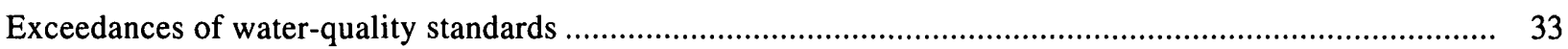

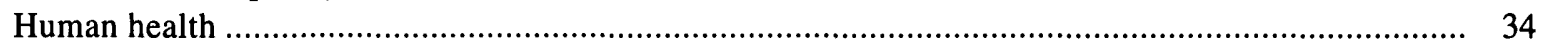

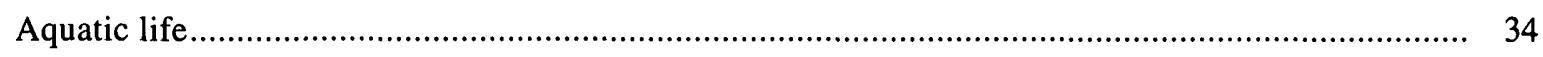

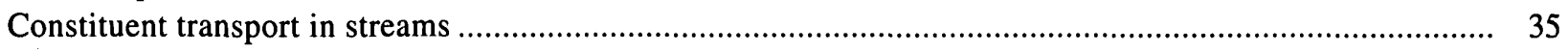

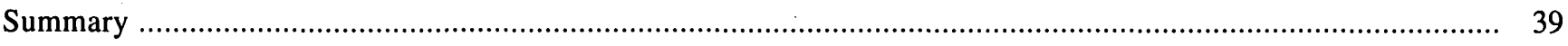

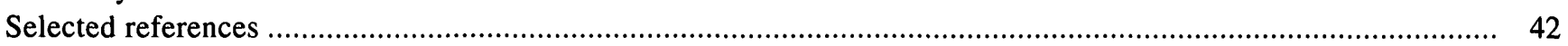




\section{ILLUSTRATIONS}

Figure 1. Map showing upper Tenmile Creek watershed and location of data-collection sites and inactive mines..... 2

2. Schematic diagram showing water sources, reservoirs, diversions, and conveyance system for the

Tenmile Water Treatment Plant near Rimini, Montana

Figures 3-7. Graphs showing:

3. Stage-discharge relationships for two sites in the upper Tenmile Creek watershed near Rimini, Montana.

4. Recorded and estimated average monthly natural discharge for Tenmile Creek near

5. Recorded daily discharge and estimated natural flow accretion and natural daily discharge for Tenmile Creek near Rimini, Montana, May-October 1997.

6. Monthly and seasonal average diversions from Beaver Creek, Tenmile Creek, and Minnehaha Creek near Rimini, Montana, May-October 1997.

7. Regression lines relating measured and observed discharge data for Moore's Spring Creek, Bear Gulch, and Tenmile Creek above Ruby Creek to concurrent estimated daily natural discharge for Tenmile Creek near Rimini, Montana

Figures 8-12. Graphs showing estimated long-term monthly natural discharge for streams, upper Tenmile

Creek watershed near Rimini, Montana:

8. Small tributary streams. 14

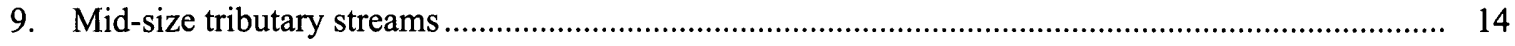

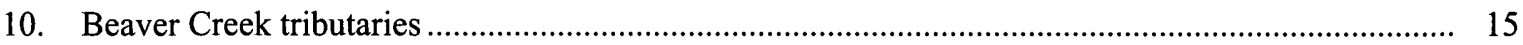

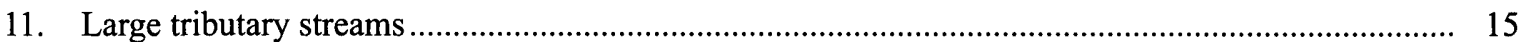

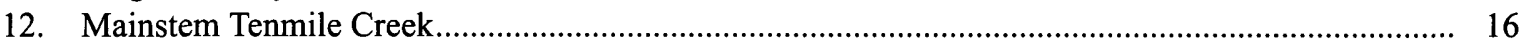

Figures 13-17. Graphs showing:

13. Estimated long-term annual natural discharge for streams in the upper Tenmile Creek watershed near Rimini, Montana

14. Estimated long-term annual unit natural discharge for streams in the upper Tenmile Creek watershed near Rimini, Montana

15. Regression relationship between selected daily mean discharge for Prickly Pear Creek and estimated daily mean natural discharge forTenmile Creek near Rimini, Montana

16. Comparison between estimated and recorded long-term mean monthly discharge for Prickly Pear Creek, Montana

17. Measured discharge and estimated error, September 6, 1998 and July 14, 1999, Tenmile Creek, upperTenmile Creek watershed near Rimini, Montana

Figures 18-21. Graphs showing total-recoverable concentrations in 1997 for selected sites in the upper Tenmile Creek watershed near Rimini, Montana:

18. Arsenic

19. Cadmium

20. Copper

21. Lead

Figures 22-25. Graphs showing instantaneous total-recoverable loads in 1997 for selected sites in the upper Tenmile Creek watershed near Rimini, Montana:

22. Arsenic.

23. Cadmium

24. Copper

25. Lead 


\section{TABLES}

Table 1. Streamflow data-collection sites and purposes, upper Tenmile Creek watershed, Montana

2. Discharge measurement sites, drainage area sizes, measurement dates, measured stage, and discharge, upper Tenmile Creek watershed, Montana

3. Net monthly discharges into Scott and Chessman Reservoirs calculated from daily water-use data at Tenmile Water Treatment Plant, Montana.

4. Monthly mean discharge diverted to Tenmile Water Treatment Plant, Montana ..................................... 50

5. Natural flow accretions for Tenmile Creek near Rimini, Montana......................................................... 51

6. Estimated average monthly and annual natural discharges for Tenmile Creek near Rimini, Montana, for water years 1961-90 based on monthly recorded discharge plus natural flow accretion ..... 52

7. Regression results for flow estimation sites, upperTenmile Creek watershed, Montana .......................... 53

8. Estimated long-term mean monthly and mean annual natural discharge for selected sites in the upper Tenmile Creek watershed, Montana

9. Streamflow sampling sites and months of water-quality sample collection during 1997, upper Tenmile Creek watershed, Montana

10. Laboratory methods, minimum reporting levels, and water-quality standards for constituents analyzed in water samples from upper Tenmile Creek watershed, Montana .....

11. Bottom-sediment sampling sites and depths, Chessman Reservoir, upperTenmile Creek watershed, Montana

12. Field-measured parameters and concentrations of major ions and nutrients in streams in the upper Tenmile Creek watershed, Montana .

13. Concentrations of trace elements and suspended sediment in streams in the upper Tenmile Creek watershed, Montana

14. Trace-element concentrations in bottom sediment from Chessman Reservoir and an adjacent wetland in the upper Tenmile Creek watershed, compared to concentrations in bottom sediment from Lake Helena, Montana

15. Equations for calculating hardness-dependent aquatic-life criteria for trace elements .

16. Calculated instantaneous loads of selected trace elements and suspended sediment in streams in the upper Tenmile Creek watershed, Montana 


\section{CONVERSION FACTORS AND ABBREVIATEDWATER QUALITY UNITS}

\begin{tabular}{rll}
\hline Multiply & By & \multicolumn{1}{c}{ To obtain } \\
\hline & & \\
cubic foot per second $\left(\mathrm{ft}^{3} / \mathrm{s}\right)$ & 0.028317 & cubic meter per second \\
cubic foot per second per day $\left(\mathrm{ft}^{3} / \mathrm{s}\right.$-day) & 2.447 & cubic meter \\
foot (ft) & 0.3048 & meter $(\mathrm{m})$ \\
inch (in.) & 25.4 & millimeter $(\mathrm{mm})$ \\
mile (mi) & 1.609 & kilometer \\
pound (lb) & 0.4536 & kilogram \\
\hline
\end{tabular}

Temperature can be converted from degrees Celsius $\left({ }^{\circ} \mathrm{C}\right)$ to degrees Fahrenheit $\left({ }^{\circ} \mathrm{F}\right)$ by the equation:

$$
{ }^{\circ} \mathrm{F}=9 / 5\left({ }^{\circ} \mathrm{C}\right)+32
$$

Abbreviated water-quality units used in this report:

$\mu \mathrm{g} / \mathrm{L} \quad$ micrograms per liter

$\mu \mathrm{S} / \mathrm{cm} \quad$ microsiemens per centimeter at 25 degrees Celsius

$\mathrm{mg} / \mathrm{L} \quad$ milligrams per liter

Water-year definition:

A water year is the 12-month period from October 1 through September 30. It is designated by the calendar year in which it ends.

Acronyms used in this report:

DNRC Montana Department of Natural Resources and Conservation

EPA U.S. Environmental Protection Agency

NWQL National Water Quality Laboratory

USGS U.S. Geological Survey 


\title{
Streamflow and Water-Quality Characteristics in the Upper Tenmile Creek Watershed, Lewis and Clark County, West-Central Montana
}

\author{
By Charles Parrett ${ }^{1}$ and Patricia S. Hettinger ${ }^{2}$
}

Abstract

A cooperative hydrologic investigation of the Upper Tenmile Creek watershed was initiated in May 1997 to obtain information for long-range watershed planning. Thirty-two stream-stage gages were established throughout the upper Tenmile Creek watershed. One new continuous-record streamflow-gaging station was established, and one discontinued continuousrecord streamflow-gaging station (Tenmile Creek near Rimini) was re-established.

Long-term monthly discharge for the 1961-90 base period was estimated at 19 of the stream-stage gages by regressing measured and observed discharge at each site in 1997 with concurrent, daily natural discharge at Tenmile Creek near Rimini. The regression relationship at each site then was used to estimate longterm monthly discharge from long-term monthly natural discharge at Tenmile Creek near Rimini.

Stream water was sampled and analyzed for water-quality constituents at 19 sites. The water-quality constituents of most concern were trace elements--such as arsenic, cadmium, copper, lead, and zinc--associated with past hard-rock mining and the naturally high trace-element content of the local rock formations. Water-quality analyses indicated that trace-element concentrations were greater than human-health standards at several sites. For example, Poison Creek, a Beaver Creek tributary, and Tenmile Creek below Spring Creek had one or more samples that exceeded the human-health standards for arsenic, cadmium, or lead. Analyses also indicated that many samples at many sites had concentrations of trace elements, particularly copper, greater than aquatic-life standards for acute toxicity. A likely source of copper at some sites was mine-waste rock or mine-adit discharge. At other sites, a likely source of copper was copper sulfate used as an algicide in Chessman Reservoir.

\section{INTRODUCTION}

Tenmile Creek is a perennial stream that is a tributary to the Missouri River and drains about 200 square miles of mountainous and valley terrain near the City of Helena in west-central Montana. Upper Tenmile Creek, defined as the reach above the Tenmile Water Treatment Plant (fig. 1), drains about 50 square miles of mostly forested, steep mountainous terrain. The headwaters are on the Continental Divide, where the maximum elevation is more than $8,000 \mathrm{ft}$. The stream flows in a generally northeasterly direction to the water treatment plant, where the elevation is about $4,400 \mathrm{ft}$.

Upper Tenmile Creek is the major source of municipal water supply for the growing community of Helena (population about 30,000). Because the drainage basin is small and located in a relatively dry mountain setting, annual and seasonal runoff is variable. Water volumes withdrawn for municipal demands often are sufficient to de-water portions of the stream in late summer, thereby rendering the aquatic habitat as unsuitable for a year-round fishery. The basin also has been impacted by substantial mining activity over the past 100 years, resulting in drainage from inactive mines entering the stream at various locations. Other land-use activities that may affect water quality in Tenmile Creek, such as logging, recreation, streamside residential development, and road traffic, are increasing.

The Upper Tenmile Watershed Steering Group, comprised of landowners and various private and public entities, was formed in 1996 to develop a watershedmanagement plan for maintaining and enhancing

\footnotetext{
${ }^{1}$ U.S. Geological Survey

${ }^{2}$ Lewis and Clark County
} 


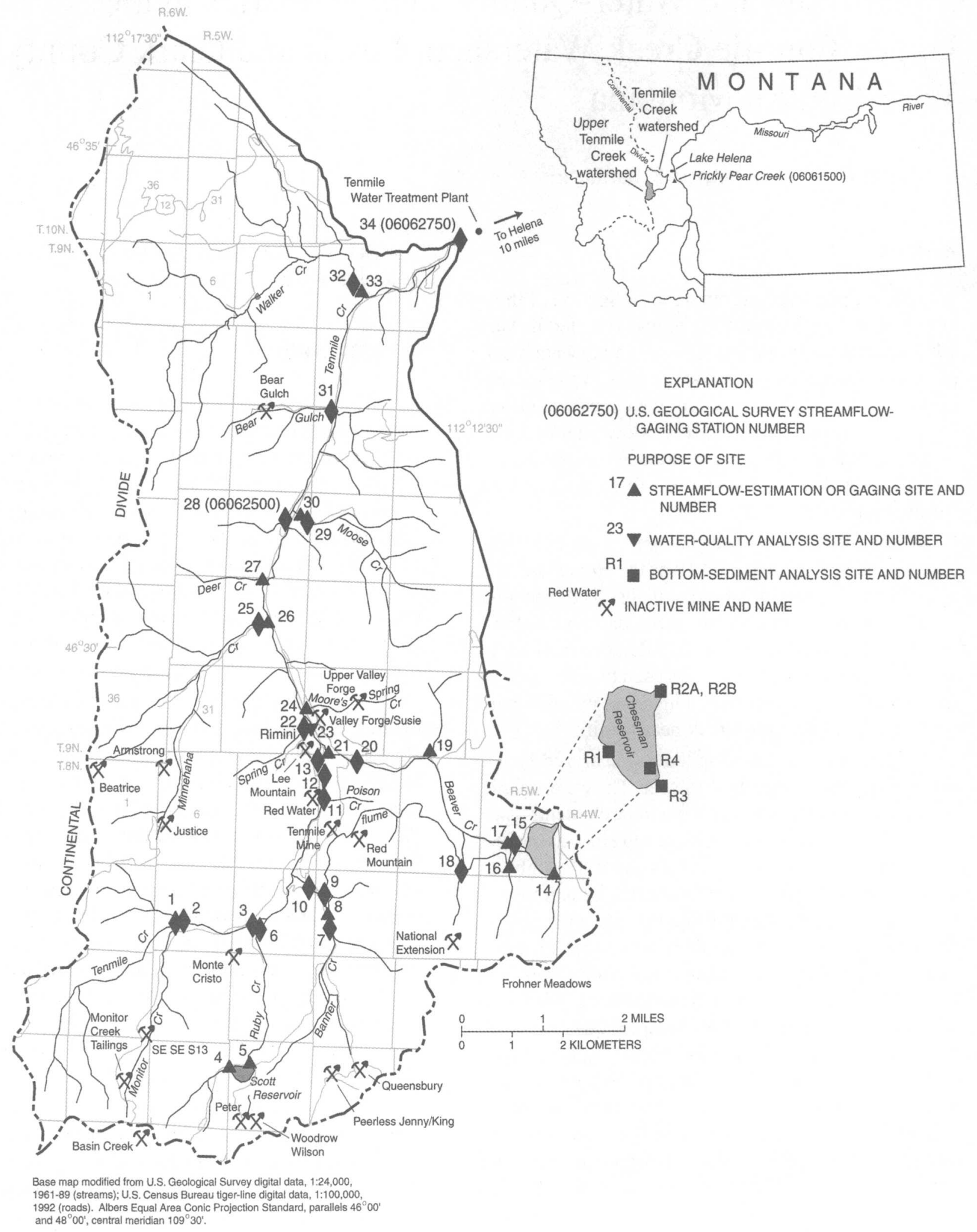

Figure 1. Upper Tenmile Creek watershed and location of data-collection sites and inactive mines. 
existing water quantity and quality within the upper watershed. Private and public entities represented on the Watershed Steering Group include Pegasus Gold Corporation; Lewis and Clark County Conservation District; City of Helena; Lewis and Clark County; Montana Department of Environmental Quality; Montana Department of Fish, Wildlife and Parks; Montana Department of Natural Resources and Conservation; U.S. Environmental Protection Agency; U.S. Forest Service; U.S. Geological Survey; and U.S. Natural Resources Conservation Service.

The Steering Group was unable to evaluate the hydrologic impacts of various watershed management alternatives because hydrologic data were available at only one location in the upper watershed. In order to meet its objective of maintaining and enhancing water quantity and quality, the Upper Tenmile Watershed Steering Group needed information about current streamflow and water-quality conditions at multiple locations in the upper Tenmile Creek watershed. Estimates of long-term natural (unaffected by human activity) monthly flows were also needed because flows in the watershed are affected by storage and withdrawals for municipal use.

\section{Purpose and Scope}

A cooperative study among the Montana Department of Natural Resources and Conservation (DNRC), Lewis and Clark County, and the U.S. Geological Survey (USGS) was initiated in 1997 to obtain hydrologic information for long-range planning in the upper Tenmile Creek watershed. The purpose of this report is to describe the methods and results of the cooperative study. The study area includes only the upper Tenmile Creek watershed, although a similar cooperative hydrologic study of the lower portion of the Tenmile Creek watershed also has been initiated.

Specific objectives established for the cooperative study were:

Objective 1: Estimate long-term, natural monthly flows at selected sites in the upper Tenmile Creek watershed.

Objective 2: Determine where Tenmile Creek gains flow from and loses flow to ground water in the 8-mile channel reach between the city's stream diversion at Rimini and the Tenmile Water Treatment Plant.

Objective 3: Characterize current water quality over a range of flow conditions and calculate instantaneous loads of selected constituents at selected sites to help identify potential sources of metal inputs.

\section{Acknowledgments}

A special word of thanks is owed to the residents and property owners of the Tenmile Creek watershed who participated in this project. Many volunteers collected staff-gage readings during May through October 1997. Their time and effort greatly assisted in the refinement of stage-discharge relationships used to estimate long-term monthly streamflow. Additional thanks go to the members of the Upper Tenmile Watershed Steering Group for their assistance in developing the grant application to fund the study and in developing the work plan. Special thanks also go to Montana Tunnels, Inc. for their generous contribution of analytical services at their laboratory. The laboratory analyzed approximately 80 water-quality samples and reruns and provided timely results and assistance to the authors. Their efforts on behalf of the Upper Tenmile Watershed Steering Group are greatly appreciated. Finally, the authors thank Robert L. Tortorelli, USGS hydrologist in Oklahoma, whose careful and thorough review materially aided this report.

\section{STUDY AREA DESCRIPTION AND HISTORICAL LAND AND WATER USE}

The upper Tenmile Creek watershed is located in the Rocky Mountains near Helena in Lewis and Clark County. The study area lies within the Northern Rocky Mountains physiographic province, which is characterized by a succession of distinct mountain ranges and valleys. Glaciation has been the predominant factor in shaping the basin's landforms and in the development of soils. Glacial features cover more than half of the basin and include cirque basins and moraine deposits, colluvial deposits, terraces and floodplains. Unglaciated terrain forms mountain slopes and ridges. Bedrock underlying the glacial materials consists mainly of Cre- 
taceous age intrusive rocks (U.S. Department of Agriculture, 1989).

The upper Tenmile Creek watershed has a continental climate modified by Pacific Ocean air masses. Winters tend to be cold and moist, and summers are warm and dry. The nearest weather station, Frohner Meadows, is located 1-mi southeast of the study area at an elevation of $6,480 \mathrm{ft}$. Based on data for 1979-98, the average annual precipitation at this location is 24.6 in. (U.S. Department of Agriculture, unpub. data, 1998). Monthly average precipitation ranges from 1.3 in. in February to 3.5 in. in May. Air temperature data at this station are available only for the period 1989-98. For this period, mean monthly temperatures range from $19.6^{\circ} \mathrm{F}$ in January to $55.8^{\circ} \mathrm{F}$ in August (Roy Kaiser, U.S. Department of Agriculture, Natural Resources Conservation Service, written commun., 1998).

The upper Tenmile Creek watershed has been the focus of numerous, generally small, hard-rock mining operations since the discovery of gold in Helena in 1864. Gold, silver, lead, and zinc mines were scattered throughout the watershed and formed the economic basis for the small community of Rimini, located about 8 miles upstream from the Tenmile Water Treatment Plant. Although all known mines are currently inactive, exposed waste-rock piles and mine spoils from the earlier mining ventures are located throughout the upper basin. These mine wastes typically contain trace metals known to be hazardous to human health and aquatic biota and constitute a potential threat to the water quality of Tenmile Creek. Inactive mine sites which have impacted or are considered to be a potential threat to streams in the watershed are shown on figure 1.

The early mining activities in the watershed required water; therefore, the first diversions and water withdrawals from Tenmile Creek were for mining purposes. In the late 1800 s, Chessman Reservoir was constructed to provide water for hydraulic mining in a small adjacent basin east of the upper watershed. Chessman Reservoir is located at the headwaters of Beaver Creek, a tributary to Tenmile Creek, and receives most of its water transported by a flume from Banner Creek, another tributary to Tenmile Creek (fig. 1).

The City of Helena began management of Chessman Reservoir in the early 1900 s to serve the municipal water needs of its growing population. Today, Helena still receives about 70 percent of its municipal water supply from the upper Tenmile Creek watershed. In addition to Chessman Reservoir, with a current storage capacity of 350 million gallons, the water collection system for the Tenmile Water Treatment Plant also includes Scott Reservoir. Scott Reservoir, with a capacity of 195 million gallons, was constructed in 1962 near the headwaters of Ruby Creek, a tributary to Tenmile Creek. Diversion structures are located on Banner Creek, Beaver Creek, Tenmile Creek, Minnehaha Creek, Moose Creek, and Walker Creek. Except for the Banner Creek diversion, which is used to transport water from Banner Creek to Chessman Reservoir via a metal flume, each diversion collects water into an underground pipe for conveyance to the Tenmile Water Treatment Plant. The treatment plant, built in 1989-90, has a maximum treatment capacity of 9 million gallons per day. Figure 2 is a schematic diagram of the water sources, reservoirs, diversions, and conveyance system for the Tenmile Water Treatment Plant.

\section{STREAMFLOW}

Streamflow in Tenmile Creek is highly variable, both on a seasonal and an annual basis, throughout the upper watershed and understanding the spatial and temporal distribution of streamflow is crucial to effective long-term watershed management. The next sections of this report describe historical streamflow, recent hydrologic data, and methods for estimation of long-term monthly flows throughout the watershed.

\section{Historical Streamflow and Hydrologic Data}

A streamflow-gaging station (station 06062500) was established by the USGS on Tenmile Creek just upstream from Moose Creek near the town of Rimini in 1914. Daily discharge data were collected from July 1914 to July 1995, when the station was discontinued. The station was re-established in May 1997 to provide information for this study. A new streamflow-gaging station (06062750) was simultaneously established at the Tenmile Water Treatment Plant (figs. 1 and 2). The mean annual streamflow of Tenmile Creek for water years 1915-94 at the USGS streamflow-gaging station near Rimini was $17.3 \mathrm{ft}^{3} / \mathrm{s}$. The maximum instantaneous discharge for the $1915-94$ period was $3,290 \mathrm{ft}^{3} / \mathrm{s}$ on May 22, 1981, and the minimum daily discharge was zero $\mathrm{ft}^{3} / \mathrm{s}$ on 45 different days over the period of record. 


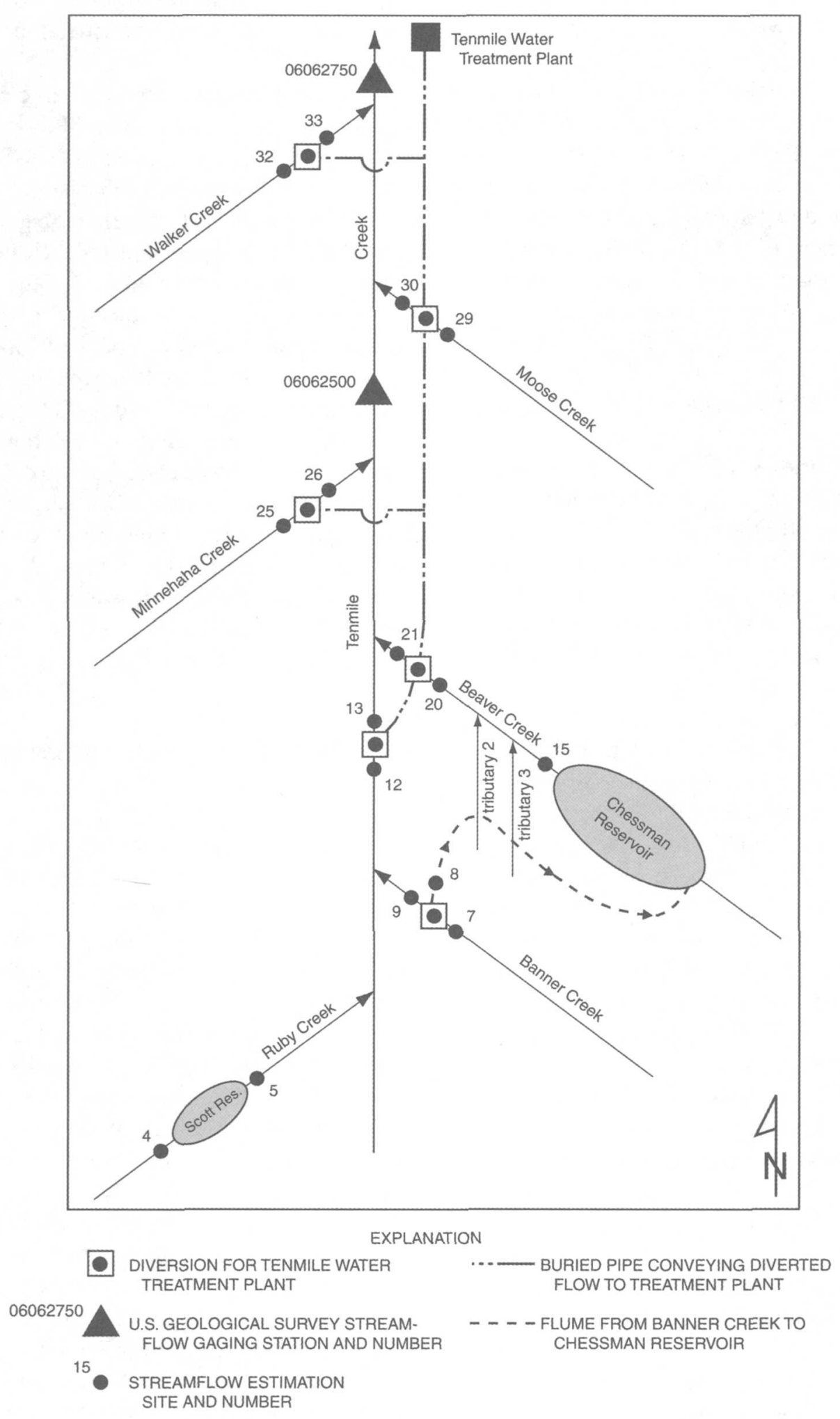

Figure 2. Water sources, reservoirs, diversions, and conveyance system for the Tenmile Water Treatment Plant near Rimini, Montana. 
Discharge data for the streamflow-gaging station on Tenmile Creek near Rimini are affected by upstream water storage and releases at Chessman and Scott Reservoirs and diversions from Banner Creek, Tenmile Creek at Rimini, Beaver Creek at Rimini, and Minnehaha Creek near Rimini (figs. 1 and 2). Diversions for the Tenmile Water Treatment Plant that are located on tributaries downstream from the streamflow-gaging station near Rimini (Moose Creek and Walker Creek) only affect recorded discharges at the new gaging station at the water treatment plant.

\section{Additional Hydrologic Data Collection in 1997}

Gages for measuring stream stage were installed at 32 locations in May 1997 to obtain additional streamflow information for the upper Tenmile Creek watershed. These sites, plus the two continuousrecording streamflow-gaging stations, are listed in downstream station order in table 1 . These sites were installed for one or more of the following three purposes: (1) estimation of long-term monthly discharge, (2) water-quality sampling and analysis, and (3) estimation of natural flow for Tenmile Creek near Rimini. Twenty-one of these 34 sites were intended for the estimation of long-term monthly natural flows throughout the basin, but two (sites 9 and 27) subsequently were dropped from further analysis because of very small flows. Twenty-one sites, most of which also were used for estimation of long-term monthly flows, were established for water-quality sampling and analysis. Sites were selected to ensure that streamflow and waterquality characteristics would be determined for all major tributaries as well as mainstem locations where flow or water-quality characteristics were expected to change as a result of diversions, inflow, or land use.

Nineteen of the 34 sites were established to help estimate the natural flow at Tenmile Creek near Rimini during 1997 that would have occurred in the absence of diversions and storage. These streamflow-estimation sites were located upstream and downstream from Chessman and Scott Reservoirs, at the Banner Creek flume, and upstream and downstream from all streamflow diversions for the Tenmile Water Treatment Plant (fig. 1). Ultimately, however, municipal water-use data compiled by the Tenmile Water Treatment Plant staff were used to determine diversion volumes and calculate natural flows for Tenmile Creek near Rimini. Thus, data from nine sites that were established solely for the purpose of 1997 natural flow estimation (table 1) were subsequently used only for verification purposes or not used at all.

Several current-meter discharge measurements were made at most of the streamflow data-collection sites using standard techniques of the USGS (Rantz and others, 1982). The measured discharges were used with concurrent water-level (stage) readings to develop stage-discharge relationships for each site, as indicated by the example graphs in figure 3 . Interested basin residents volunteered to periodically record stage at most sites throughout the May through October period. The stage-discharge relations then were used to determine discharge for each stage reading. Discharges determined from the stage-discharge relations are herein referred to as observed discharges to differentiate them from measured discharges. Discharges determined from stage readings in flumes operated by personnel at the Tenmile Water Treatment Plant also are referred to as observed discharges. Measurement-site description, drainage basin size, measurement dates, and measured stage and discharge for each site are shown in table 2.

\section{Techniques for Estimation of Long-Term Monthly and Daily Discharge}

To estimate long-term monthly natural discharges at locations throughout the upper basin, a multi-step correlation procedure was used.

Step 1: Water-use data based on metered usage and observed discharges for the Tenmile Water Treatment Plant for water years 1991-98 and October 1998 (first month of water year 1999) and measured discharge data from May through October 1997 for this study were used to estimate long-term monthly natural discharges for 1961-90, a commonly used base period for meteorologic and hydrologic analyses, for Tenmile Creek near Rimini.

Step 2: Metered water-use data and observed discharges for the Tenmile Water Treatment Plant and measured discharge for the current study were used to estimate daily natural flows for May through October 1997 for Tenmile Creek near Rimini.

Step 3: Measured and observed discharges during May through September 1997 at 19 monthly flow-estimation sites were regressed with concurrent estimated daily natural discharges for Tenmile Creek near Rimini. The regression relation then was used to estimate long-term monthly natural flows at each of 


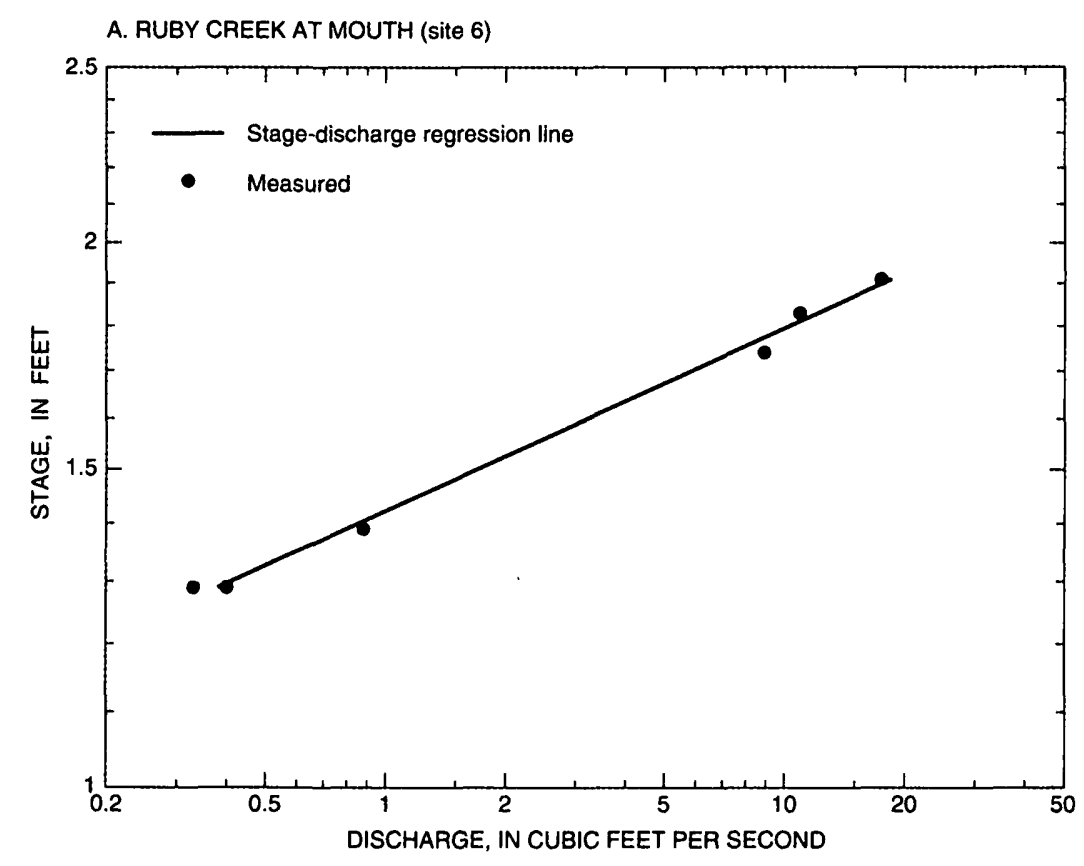

B. WALKER CREEK ABOVE CITY DIVERSION (site 32)

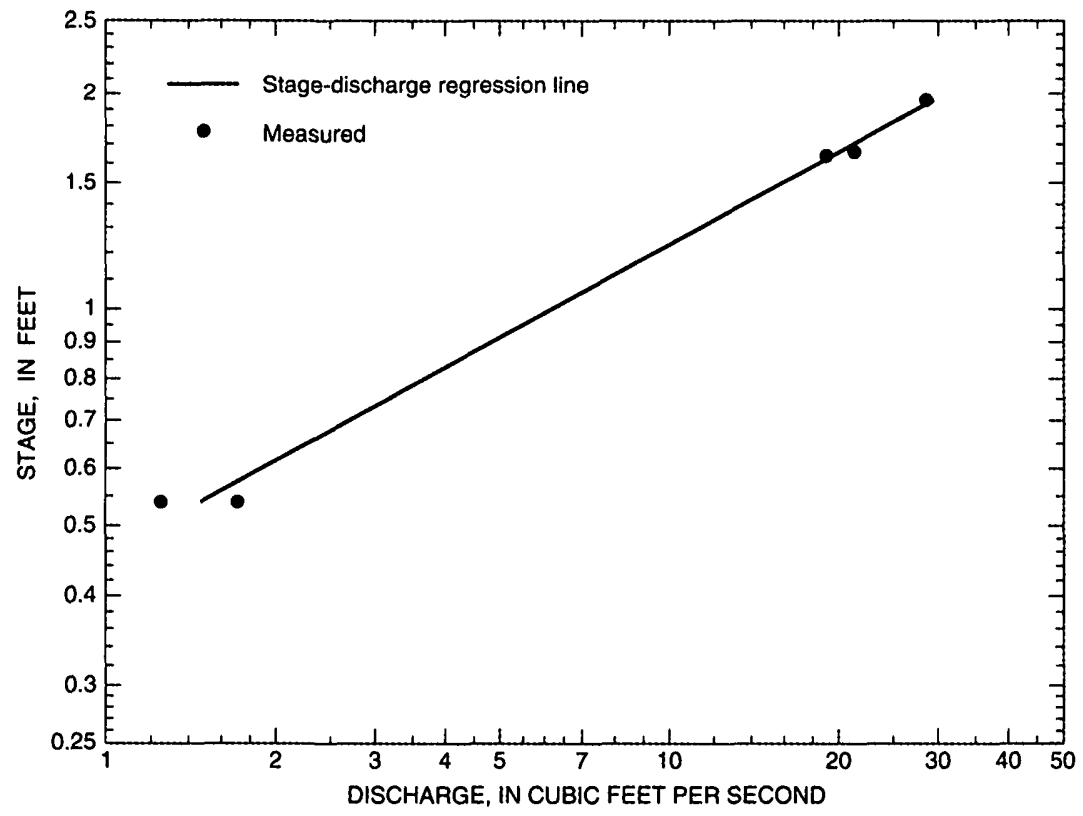

Figure 3. Stage-discharge relationships for two sites in the upper Tenmile Creek watershed near Rimini, Montana. 
the 19 sites from the long-term monthly natural flows for Tenmile Creek near Rimini. Each step in the correlation procedure is described in detail in the following sections of the report.

\section{Estimation of Long-Term Monthly Natural Flows for Tenmile Creek near Rimini}

As previously described, recorded daily discharges for station 06062500 on Tenmile Creek near Rimini are affected by flow diversions for municipal water supply on Banner Creek, Tenmile Creek at Rimini, Beaver Creek, and Minnehaha Creek (figure 2). Storage and releases from Scott and Chessman Reservoirs also affect recorded discharges. As shown on the schematic diagram in figure 2, diversions from Moose and Walker Creeks are downstream from station 06062500 and do not affect recorded discharges at that station.

Total water diverted to the Tenmile Water Treatment Plant is metered daily at the inflow pipe to the plant. Personnel at the plant also periodically observe discharge at measuring flumes upstream and downstream from Scott Reservoir (sites 4 and 5, respectively), at the Banner Creek diversion (site 8), and downstream from Chessman Reservoir (site 15). Net daily discharge at each of these sites is estimated by interpolating between periodically observed discharges. Net daily discharge into Scott Reservoir is computed by subtracting daily discharge at measurement site 5 from daily discharge at site 4 . Similarly, net daily discharge into Chessman Reservoir is computed by subtracting daily discharge at measurement site 15 from daily discharge at measurement site 8 . Net daily discharge into either reservoir is negative whenever outflow exceeds inflow. Computed net daily discharges are averaged for each month to produce estimates of net monthly mean discharge into each reservoir. Daily water-use data for the Tenmile Water Treatment Plant for water years 1991-98 and October 1998 (Jack Williams, Tenmile Water Treatment Plant, written commun.,1998) were used to calculate monthly mean data shown in table 3.

Access to Scott Reservoir is difficult during early runoff conditions in May; consequently, daily discharge into the reservoir probably is often underestimated during runoff periods when site 4 is not observed. Likewise, the method used to compute net daily discharge into Chessman Reservoir does not include Beaver Creek inflows (site 14) or inflows to the
Banner Creek flume from Beaver Creek tributaries 2 and 3 (sites 16 and 18). Thus, the method also tends to underestimate the true net discharge into Chessman Reservoir.

To estimate the additional discharge into Scott and Chessman Reservoirs, monthly mean water-use data for the 1991-98 water years and October 1998 were used to calculate the average net monthly discharge into each reservoir. As shown in table 3, the average monthly net flow into Scott Reservoir was $-0.71 \mathrm{ft}^{3} / \mathrm{s}$, and the average monthly net flow into Chessman Reservoir was $-0.46 \mathrm{ft}^{3} / \mathrm{s}$. Because both reservoirs are relatively small, it was assumed that they would empty and fill annually. On that basis, the true average net annual discharge from the reservoirs over the 1991-98 period was assumed to be zero. The additional average monthly flow into Scott and Chessman Reservoirs necessary to balance the negative inflows calculated from water-use data was assumed to be 0.71 and $0.46 \mathrm{ft}^{3} / \mathrm{s}$, respectively. Loss from evaporation was assumed to be negligible, due to the small surface areas of the two reservoirs. The additional inflow to the reservoirs was considered to occur only during the spring runoff period of May and June; therefore, the actual distribution of the underestimated annual discharge into each reservoir was weighted to the two months of May and June. For Scott Reservoir, the average additional May and June inflow required to ensure a true average net annual discharge of zero is $\left(0.71 \mathrm{ft}^{3} / \mathrm{s} \times 12\right.$ months $) /(2$ months $)$, or $4.3 \mathrm{ft}^{3} / \mathrm{s}$. For Chessman Reservoir, the average additional May and June inflow required to ensure a true average net annual discharge of zero is $\left(0.46 \mathrm{ft}^{3} / \mathrm{s} \mathrm{x} 12\right.$ months $) /(2$ months $)$, or $2.8 \mathrm{ft}^{3} / \mathrm{s}$.

To estimate monthly natural discharge for Tenmile Creek near Rimini (site 28), the combined net monthly discharge into the reservoirs is added to recorded monthly discharge at the streamflow-gaging station. Streamflow losses resulting from natural seepage to ground water between the reservoirs and site 28 were assumed to be negligible. In addition, discharge diverted to the treatment plant, minus that portion below the gage that comes from Moose Creek and Walker Creek, is added to recorded discharge at the streamflow-gaging station. Table 4 shows total monthly mean discharge diverted to the treatment plant for water years 1991-98 and October 1998; discharge from individual diversions is unknown.

Discharges measured during 1997 were used to estimate the average diversion from Moose Creek and 
Walker Creek compared to the average diversion from Tenmile, Beaver, and Minnehaha Creeks . Based on information from operators at the Tenmile Water Treatment Plant (Leonard Willett, oral commun., 1998), diversions from each stream are roughly proportional to their discharges. Based on four approximately concurrent measurements of discharge at the measurement site above each diversion in mid-May, early June, early August, and late August, the combined discharges for Moose and Walker Creeks were about 0.20 times (20 percent) the combined discharges for Tenmile, Beaver, and Minnehaha Creeks. Thus, the average annual diversion from Moose and Walker Creeks was assumed to be 20 percent of the average annual diversion from Tenmile, Beaver, and Minnehaha Creeks. On this basis, total average annual diversion to the Tenmile Water Treatment Plant would equal the average annual diversion to the Tenmile, Beaver, and Minnehaha Creeks plus 0.20 times the average annual diversion from Tenmile, Beaver, and Minnehaha Creeks. Stated another way, the average annual diversion from Tenmile, Beaver, and Minnehaha Creeks equals the total average annual diversion to the treatment plant divided by 1.20 , or 83 percent of the total average annual diversion. Estimated monthly discharges diverted from Tenmile, Beaver, and Minnehaha Creeks for water years 1991-98 and October 1998 were estimated to be 83 percent of the total monthly discharges diverted to the Tenmile Water Treatment Plant (table 4).

Estimated monthly discharges diverted to the Tenmile Water Treatment Plant from Tenmile, Beaver, and Minnehaha Creeks then were added to the combined estimated net monthly discharges into Scott and Chessman Reservoirs. The results, termed natural flow accretions, represent the difference between recorded monthly discharges and natural monthly discharges for Tenmile Creek near Rimini. These natural flow accretions and their averages for water years 1991-98 and October 1998 are listed in table 5.

Although no data for natural flow accretions are available before water year 1991, estimated water-use data compiled by the City of Helena for 1978-97 (Leonard Willett, written commun., 1998) indicate that the average annual municipal water supply from the Tenmile Creek basin for water years 1978-97 $\left(5.4 \mathrm{ft}^{3} / \mathrm{s}\right)$ was about the same as that for water years 1991-98 and October $1998\left(5.6 \mathrm{ft}^{3} / \mathrm{s}\right)$. On this basis, the average natural flow accretions for water years 1991-98 and October 1998 are assumed to be the same as for the longer 1978-97 period. The 1978-97 base period, because of its short length, is not considered a suitable base period for the estimation of long-term mean flows for the upper Tenmile Creek basin. Accordingly, a 30-year base period including water years 1961-90, which is a common length of record used for long-term climatic comparisons, was used for the estimation of long-term flows in the Tenmile Creek basin. The average natural flow accretions for the 1991-98 period also were assumed to be the same as those for 1961-90. Although municipal water use in Helena has likely increased over the years due to increasing population, efficiency of the Tenmile water delivery system also has improved as leaky wooden supply lines have been replaced by steel pipes. Increasing municipal demands for water in Helena also have partially been met since 1959 by water supplied from the Missouri River. For these reasons, the assumption that natural flow accretions for Tenmile Creek have remained relatively constant since 1961 seemed reasonable.

Estimated average monthly natural discharges for the 1961-90 base period for Tenmile Creek near Rimini were calculated by adding average natural flow accretions to average monthly recorded discharges for the 1961-90 base period (table 6). Estimated average monthly natural discharges are graphically compared to monthly recorded discharges in figure 4 . As shown in table 6 and figure 4, differences between natural and recorded discharges are greatest in May and June when streamflows are naturally high from snowmelt runoff and Scott and Chessman Reservoirs are being filled. Differences between natural and recorded discharges are least in December, January, and February when streamflows are naturally low, and diversions to the Tenmile Water Treatment Plant are largely supplied from Chessman and Scott Reservoir releases.

\section{Estimation of Daily Natural Discharge for May-October 1997 for Tenmile Creek near Rimini}

To estimate daily natural discharge forTenmile Creek near Rimini for the May-October 1997 period, daily water-use data supplied by personnel at the Tenmile Water Treatment Plant were used. The procedure for estimation of daily natural discharge was similar to that for the estimation of long-term monthly natural flows. Daily discharges diverted to the Tenmile Water Treatment Plant from Tenmile, Beaver, and Minnehaha Creeks were added to the combined net daily discharges into Scott and Chessman Reservoirs to produce estimated daily natural flow accretions for the gage at 


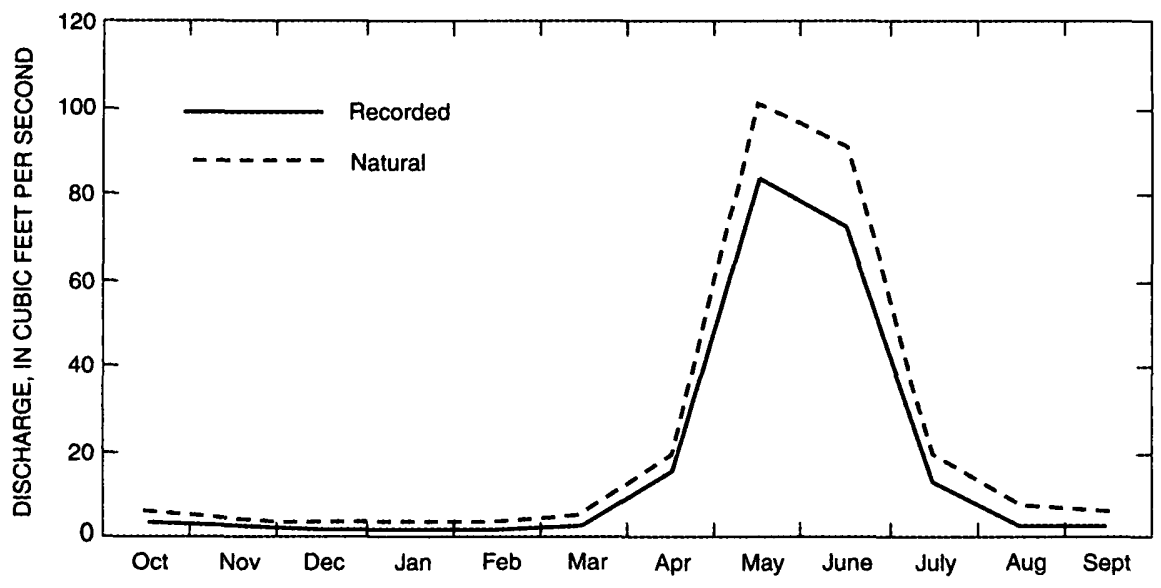

Figure 4. Recorded and estimated average monthly natural discharge for Tenmile Creek near Rimini, Montana (site 28), water years 1961-90.

Tenmile Creek near Rimini. The estimated natural flow accretions were added to the recorded discharges for Tenmile Creek near Rimini to produce estimates of daily natural flow for the May through October 1997 period. Calculations were simpler than those required for estimation of long-term monthly natural discharges, because no diversions to the Tenmile Water Treatment Plant were made from Moose Creek or Walker Creek during May through October 1997.

As previously described, data for discharge into Scott and Chessman Reservoirs do not account for early-season inflows to Scott Reservoir or for inflows to Chessman Reservoir from Beaver Creek or its tributaries. To estimate the additional daily discharge into Scott and Chessman Reservoirs during May through October 1997, the previously calculated average values for May and June were used together with the distribution of daily recorded discharge for Tenmile Creek near Rimini for May and June. The total discharge volume for May and June 1997 for Tenmile Creek near Rimini was the sum of all daily discharges over the 61-day period, or $6,248 \mathrm{ft}^{3} / \mathrm{s}$-days. For that same 61 -day period, the total additional inflow volume to Scott Reservoir was $4.3 \mathrm{ft}^{3} / \mathrm{s} \mathrm{x} 61$ days, or $262 \mathrm{ft}^{3} / \mathrm{s}$-days, and the total additional inflow volume to Chessman Reservoir was $2.8 \mathrm{ft}^{3} / \mathrm{s} \times 61$ days, or $171 \mathrm{ft}^{3} /$ days. The additional inflow volume for Scott Reservoir was $(262 / 6,248)$, or 4.2 percent of the discharge volume for Tenmile Creek near Rimini. Similarly, the additional inflow volume for Chessman Reservoir was (171/6,248), or 2.7 per- cent of the discharge volume for Tenmile Creek near Rimini. Thus, for example, the estimated additional inflow for Scott Reservoir on May 1, when the recorded daily discharge for Tenmile Creek near Rimini was $25 \mathrm{ft}^{3} / \mathrm{s}$, was 4.2 percent of $25 \mathrm{ft}^{3} / \mathrm{s}$, or 1.0 $\mathrm{ft}^{3} / \mathrm{s}$. Similarly, the estimated additional inflow to Chessman Reservoir on May was 2.7 percent of $25 \mathrm{ft}^{3} / \mathrm{s}$, or $0.68 \mathrm{ft}^{3} / \mathrm{s}$.

Recorded daily discharge, estimated daily natural flow accretions, and estimated daily natural discharge for Tenmile Creek near Rimini for May 1 through October 31, 1997 are displayed graphically in figure 5 . Figure 5 indicates that the largest daily natural flow accretions occurred in May and June, and the smallest occurred in October.

Measured and observed discharges at sites above and below the diversion structures on Tenmile Creek at Rimini, Beaver Creek at Rimini, and Minnehaha Creek near Rimini were used to estimate the proportion of flow diverted to the Tenmile Water Treatment Plant from each diversion during May 1 through October 31, 1997. Monthly average discharge diverted and the total May through October average discharge diverted at the three diversions are shown in figure 6 . As indicated by the average values for the period (figure 6), the greatest amount of flow (about 48 percent) was provided by the Beaver Creek diversion, while about equal amounts (about 26 percent each) were supplied by the Tenmile Creek and Minnehaha Creek diversions. 


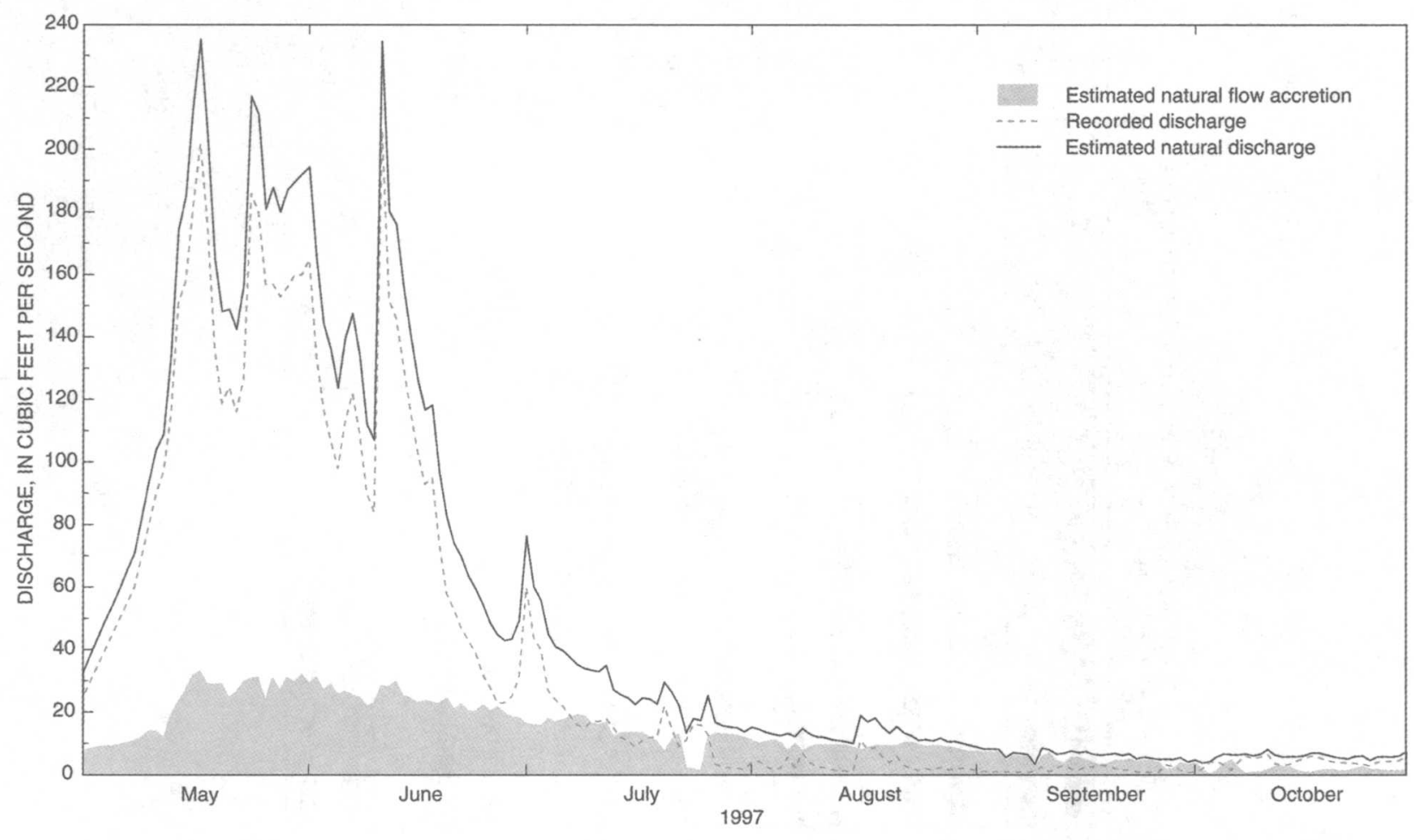

Figure 5. Recorded daily discharge and estimated natural flow accretion and natural daily discharge for Tenmile Creek near Rimini, Montana (site 28), May-October 1997.

Estimation of Long-Term Monthly Natural Discharge for Selected Sites

In addition to the previously described techniques used to estimate long-term monthly natural discharge for Tenmile Creek near Rimini, regression analysis was used to estimate long-term monthly natural discharge at each of the other 18 flow-estimation sites. Each measured and observed discharge (Y value) was paired with the concurrent estimated daily natural discharge for Tenmile Creek near Rimini (X value). An Ordinary Least Squares (OLS) regression line was fit to the base 10 logarithms of the paired data. The relation of daily values was assumed to also represent the relation of monthly discharges and, therefore, was subsequently used to estimate long-term monthly discharge. The resultant equations for the regression lines may be expressed in the following log-linear form,

$$
\mathrm{Y}=\mathrm{a}^{\prime} \mathrm{X}^{\mathrm{b}}
$$

where
$\mathrm{Y}$ is the daily or monthly discharge for the estimation site, in cubic feet per second;

$\mathrm{X}$ is the daily or monthly natural discharge for Tenmile Creek near Rimini, in cubic feet per second;

$a^{\prime} \quad$ is the anti-log of the linear regression constant $\left(\mathrm{a}^{\mathrm{\prime}}=10^{\mathrm{a}}\right)$, and;

b is the linear regression coefficient.

The $\mathrm{a}^{\prime}$ and $\mathrm{b}$ values for the regression equations and two measures of regression reliability, the coefficient of determination $\left(\mathrm{R}^{2}\right)$, and the standard error of estimate (SE), for all estimation sites are shown in table 7. The coefficient of determination is a measure of the percentage of the variation in $\mathrm{Y}$ that is accounted for by the regression equation. The standard error of estimate is a measure of the dispersion of the data around the regression line.

In general, the larger the value of $\mathrm{R}^{2}$ and the smaller the value of SE, the more reliable is the regression equation. The regressions for all sites but one had 


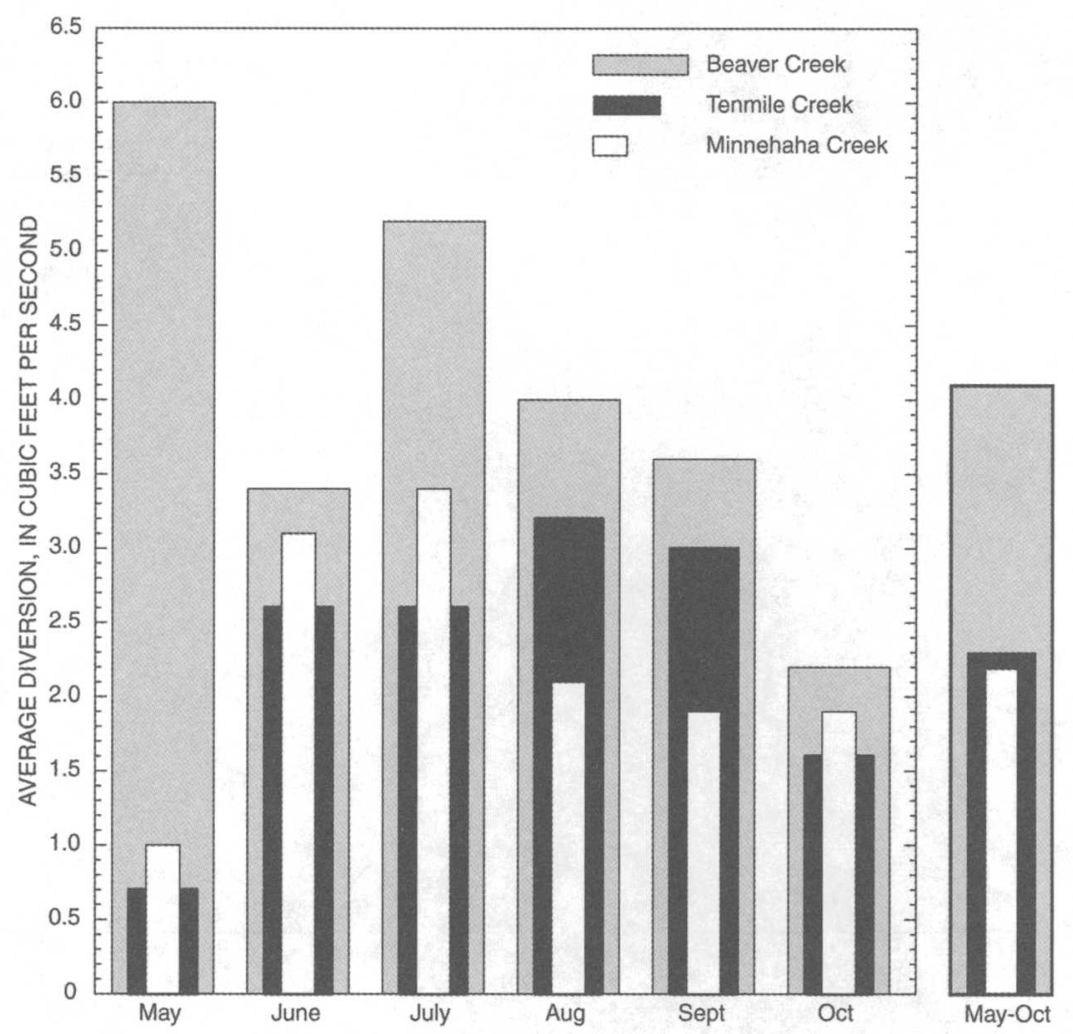

Figure 6. Monthly and seasonal average diversions from Beaver Creek, Tenmile Creek, and Minnehaha Creek near Rimini, Montana, May-October 1997.

relatively large values for $\mathrm{R}^{2}(0.70$ or greater) and for all had small values of SE (0.06-0.21) (table 7).

Moore's Spring Creek (site 24), where measured and observed discharges were very small and relatively constant throughout the May through October measurement period, was the only site that lacked a significant correlation to flow at Tenmile Creek near Rimini. The regression equation for Moore's Spring Creek, with a p-value of 0.78 , was the only one that was not statistically significant. The p-value represents the probability that the regression equation is not significant. All other regression equations had $\mathrm{p}$ values less than 0.01 and thus were statistically significant.

Two of the "worst" (sites 24 and 31) and one of the "best" (site 3) regressions in terms of the values of $\mathrm{R}^{2}$ and SE in table 7 are shown graphically in figure 7 . The logarithms of estimated natural discharge for Tenmile Creek near Rimini are only very weakly correlated with measured and observed discharges for Moore's
Spring Creek (fig. 7A) but are more strongly correlated with measured and observed discharges for Bear Gulch (fig. 7B). In contrast, estimated natural discharges for Tenmile Creek near Rimini are very strongly correlated with measured and observed discharges for Tenmile Creek above Ruby Creek (fig. 7C). Similarly strong correlations exist for most of the streamflow-estimation sites.

To calculate long-term monthly natural discharge for an estimation site, each monthly value of long-term natural discharge for Tenmile Creek near Rimini (table 6) was entered as the $\mathrm{X}$ value in equation 1 , together with appropriate values of $a$ ' and $b$ from table 7. For example, the long-term October discharge for Monitor Creek (site 1), Y, was estimated from the long-term October natural discharge for Tenmile Creek near Rimini $\left(6.1 \mathrm{ft}^{3} / \mathrm{s}\right)$ as follows:

$$
\mathrm{Y}=\mathrm{a}^{\prime} \mathrm{X}^{\mathrm{b}}
$$


A. Moore's Spring Creek (site 24)

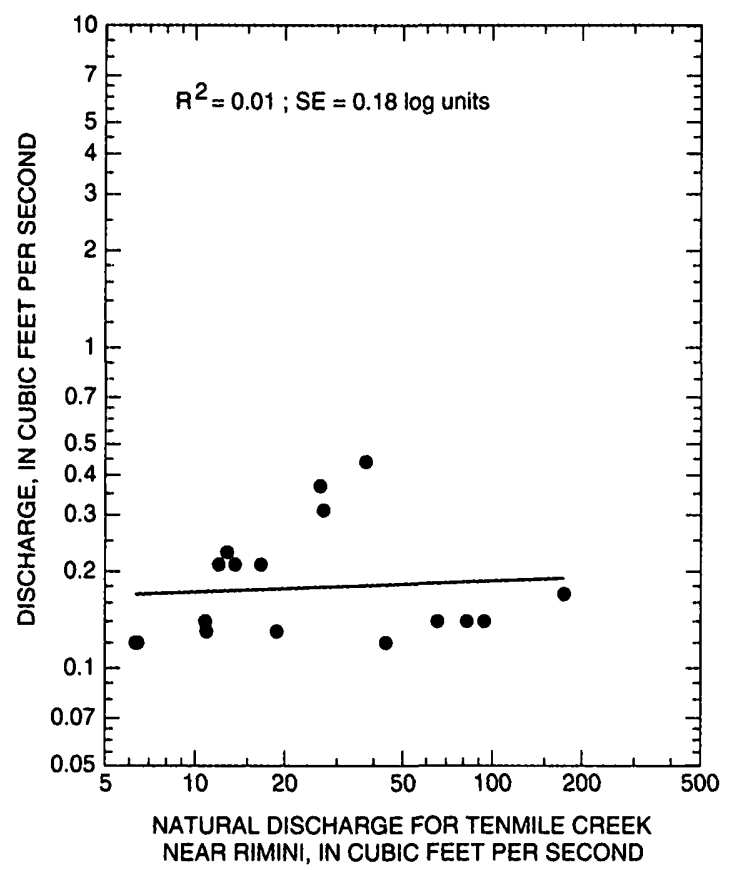

C. Tenmile Creek above Ruby Creek (site 3)

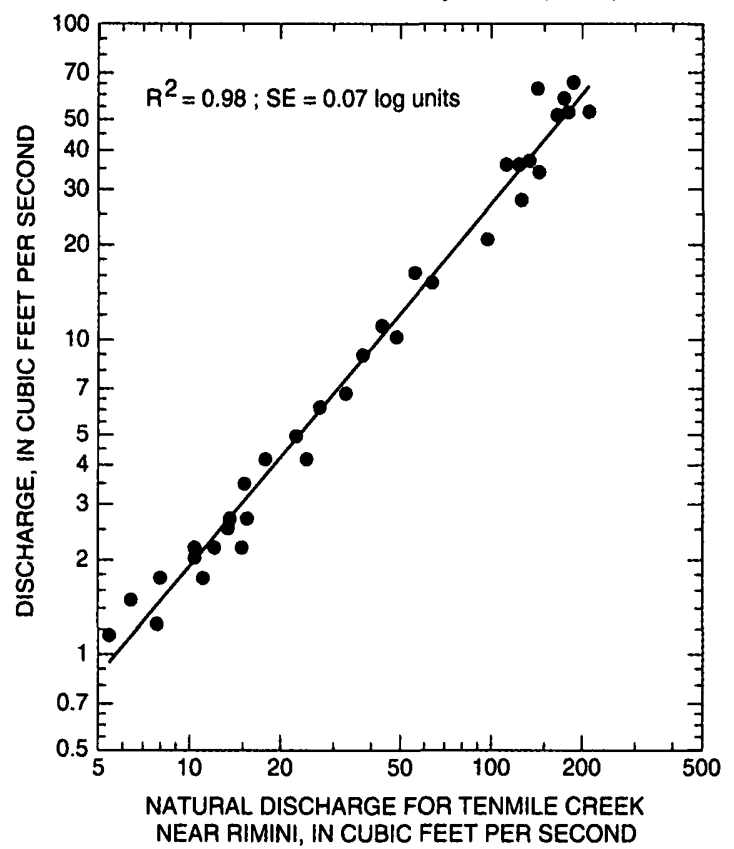

B. Bear Gulch (site 31)

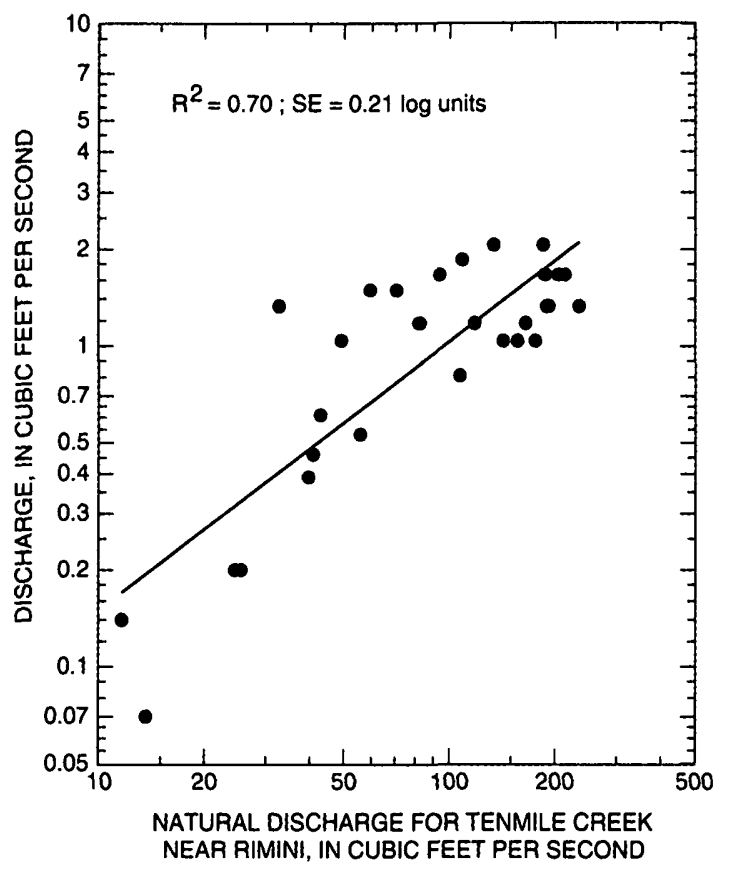

EXPLANATION

REGRESSION LINE

- MEASURED OR OBSERVED DISCHARGE

Figure 7. Regression lines relating measured and observed discharge data for Moore's Spring Creek, Bear Gulch, and Tenmile Creek above Ruby Creek to concurrent estimated daily natural discharge for Tenmile Creek near Rimini, Montana (site 28). 
where:

$a^{\prime}$ and $b$ from table 7 are 0.026 and 1.12 , respectively; and

$\mathrm{X}$ is $6.1 \mathrm{ft}^{3} / \mathrm{s}$.

Thus,

$$
\begin{aligned}
\mathrm{Y} & =(0.026)(6.1)^{1.12}, \\
\mathrm{Y} & =(0.026)(7.6), \\
\mathrm{Y} & =0.20 \mathrm{ft}^{3} / \mathrm{s} .
\end{aligned}
$$

In a similar manner, long-term mean monthly natural discharges for all months and all estimation sites were calculated and are shown in table 8 . Also shown in table 8 are estimates of long-term mean annual natural discharge for each site. Long-term mean annual natural discharge was calculated by multiplying each long-term mean monthly natural discharge by the number of days in the month, summing the 12 resultant values, and dividing the sum by 365 days.

Results in table 8 are displayed graphically in figures 8 through 12 . Figure 8 shows the long-term monthly natural discharge estimates for smaller streams in the watershed and indicates that Moore's Spring Creek (site 24) flows generally had less variation than flows for other small tributaries. Figure 9 shows long-term monthly natural discharge estimates

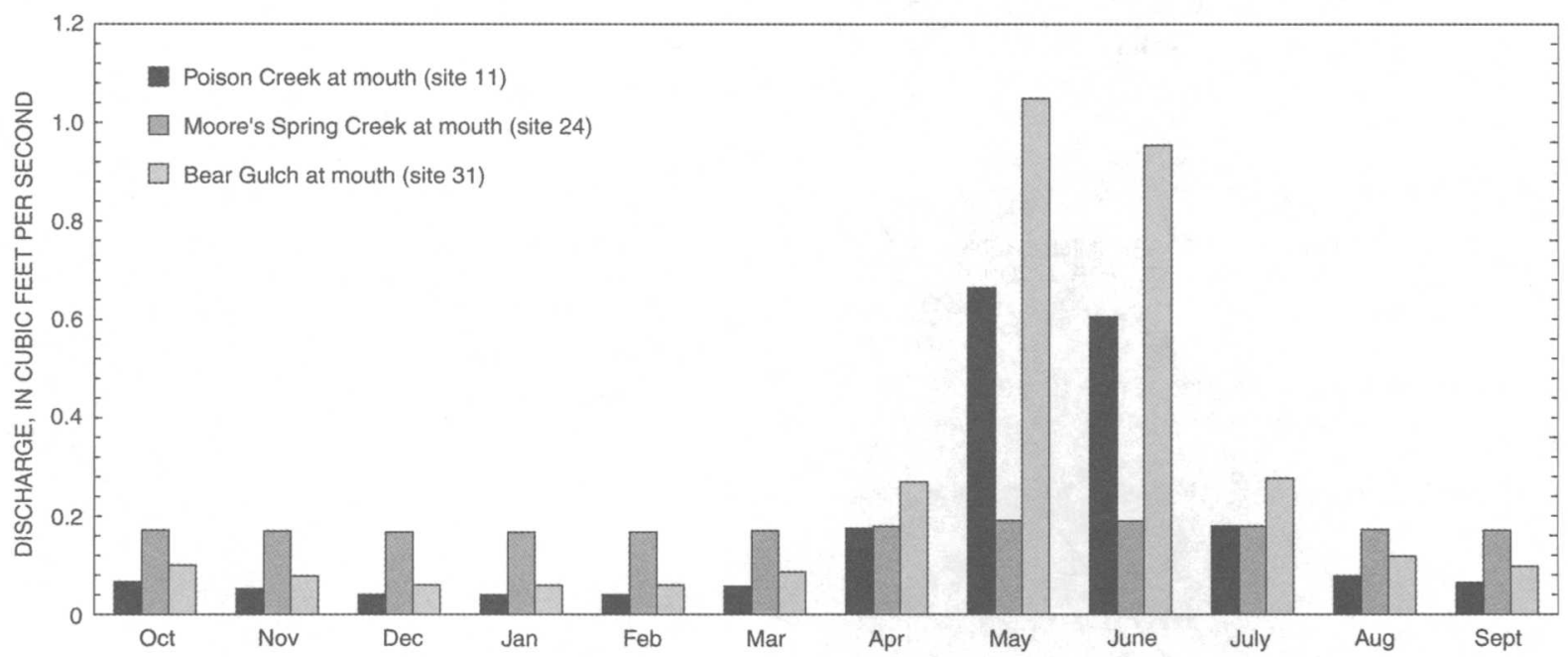

Figure 8. Estimated long-term monthly natural discharge for small tributary streams, upper Tenmile Creek watershed near Rimini, Montana.

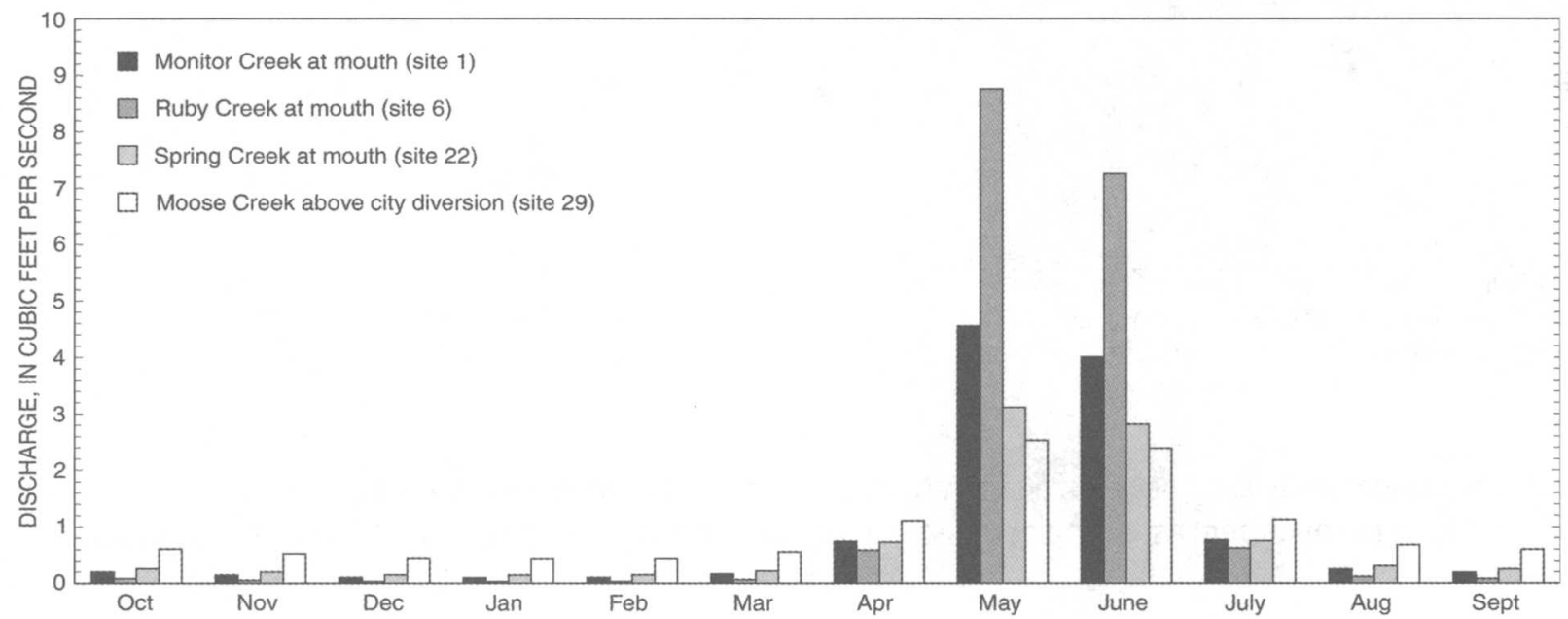

Figure 9. Estimated long-term monthly natural discharge for mid-size tributary streams, upper Tenmile Creek watershed near Rimini, Montana. 
for mid-sized Tenmile Creek tributaries and indicates that Moose Creek (site 29) flows generally had less variation than other mid-sized tributaries. Figure 10 shows long-term monthly natural discharge estimates for the three Beaver Creek tributaries and indicates that tributaries 1 and 2 have similar flows with less variation than those of tributary 3 . Long-term monthly natural discharge estimates for the largest Tenmile Creek tributaries are compared in figure 11. Figure 11 shows that estimated long-term monthly natural discharges for Beaver Creek (site 20) and Minnehaha Creek (site 25) are similar in magnitude and variability, and that monthly natural discharges for Walker Creek (site 32), the tributary with the largest drainage area (table 2), are less than those for the other large tributaries. Finally, figure 12 shows long-term monthly natural discharge estimates for the mainstem sites on Tenmile Creek. Figure 12 shows that monthly natural discharge for Tenmile Creek increases in the downstream direction, as a result of tributary inflows.

Long-term annual natural discharges for all estimation sites are compared in figure 13. Figure 13 shows the pattern of natural discharge increases in Tenmile Creek in the downstream direction and the relative

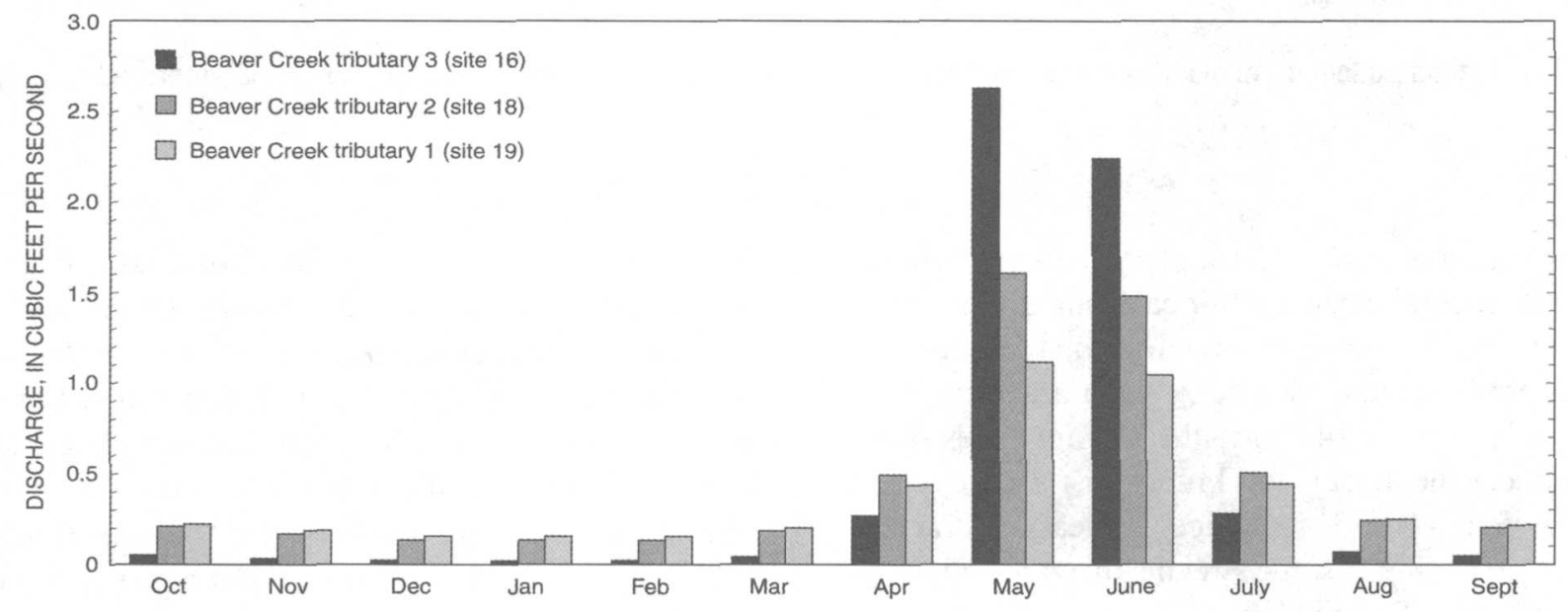

Figure 10. Estimated long-term monthly natural discharge for Beaver Creek tributaries, upper Tenmile Creek watershed near Rimini, Montana.

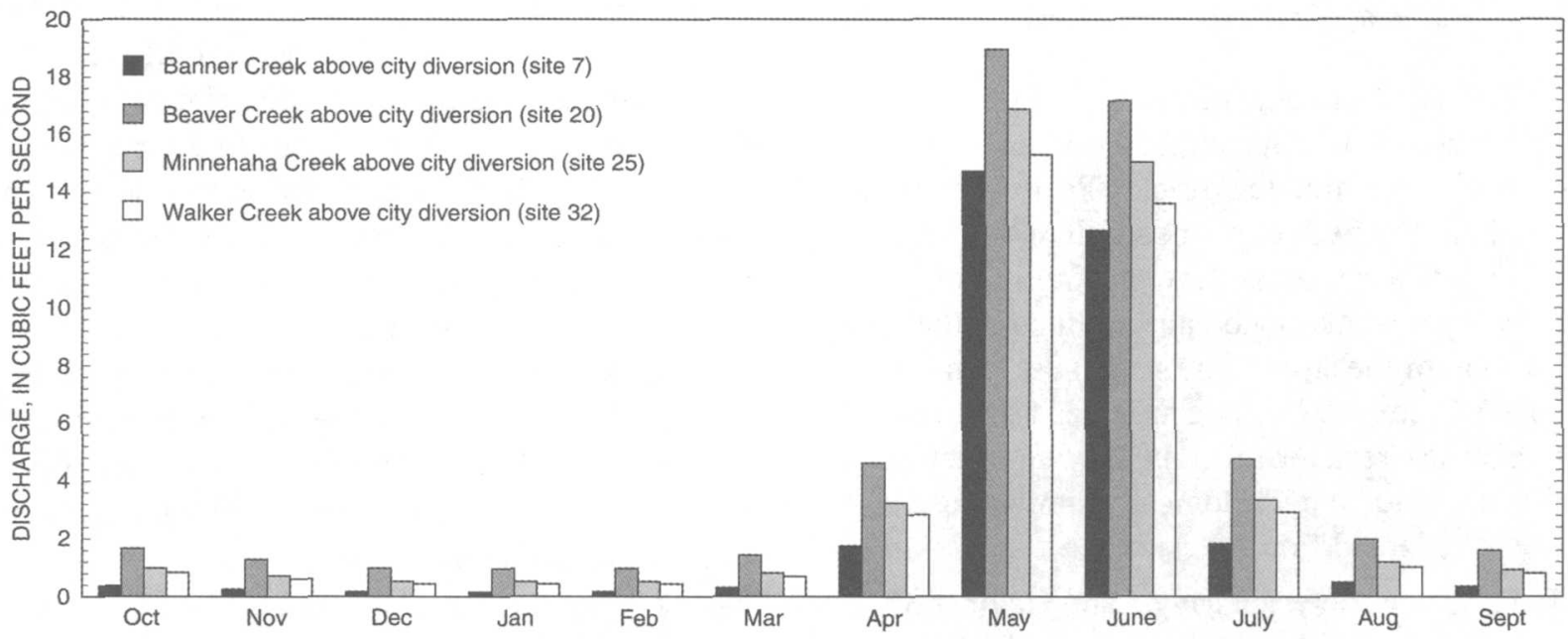

Figure 11. Estimated long-term monthly natural discharge for large tributary streams, upper Tenmile Creek watershed near Rimini, Montana. 


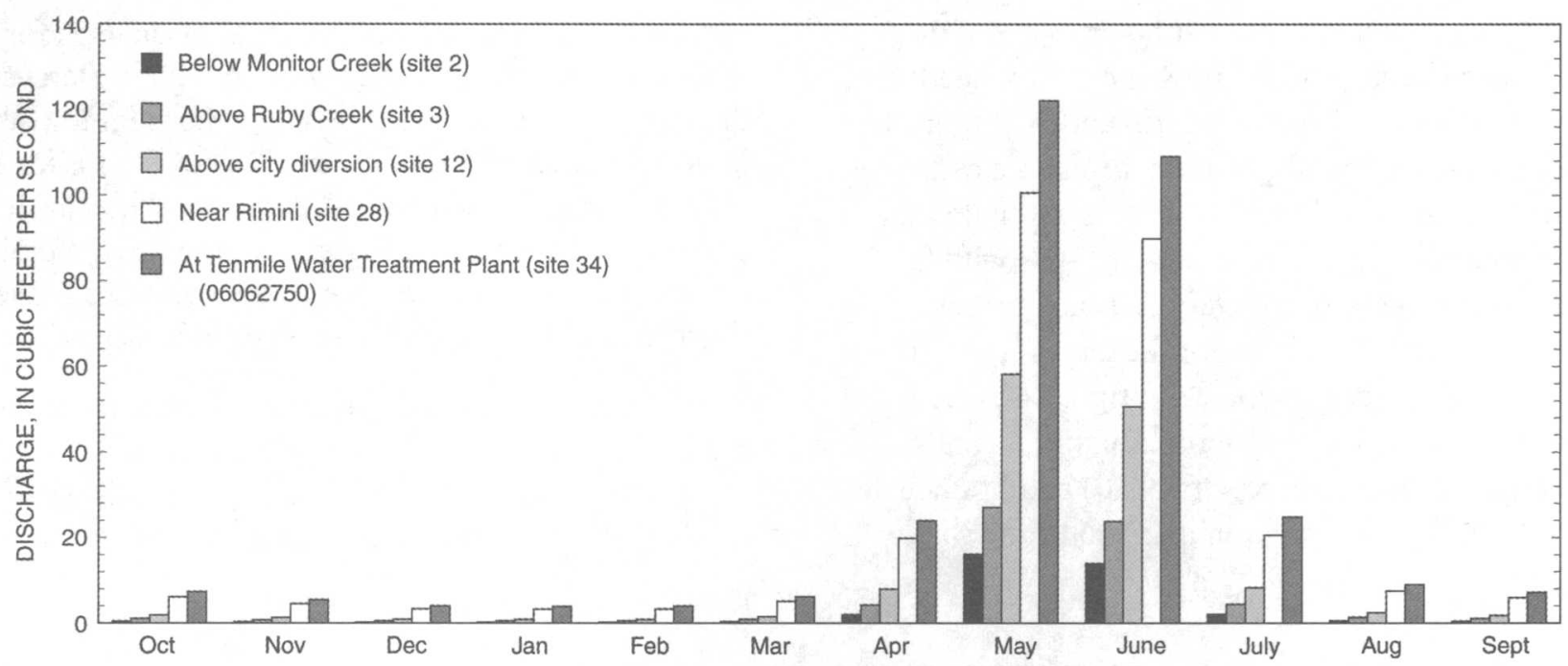

Figure 12. Estimated long-term monthly natural discharge for mainstem Tenmile Creek, upper Tenmile Creek watershed near Rimini, Montana.

flow contribution from each tributary. Figure 14 shows the annual natural discharge for each site divided by drainage area and provides an indication of which streams produce the most estimated natural runoff per square mile. Figure 14 shows that Spring Creek (site 22) produces the most natural runoff per square mile, and Bear Gulch (site 31) produces the least natural runoff per square mile. Of the streams that currently supply water to the Tenmile Water Treatment Plant, Banner Creek (site 7) produces the most natural runoff per square mile, and Walker Creek (site 32) produces the least natural runoff per square mile.

\section{Reliability of Long-Term Monthly Discharge Estimates}

Gaged data from a nearby stream (Prickly Pear Creek) were used to test the reliability of the long-term monthly discharge estimates. Prickly Pear Creek arises in the Northern Rocky Mountains south of the Tenmile Creek basin and has a streamflow-gaging station (06061500) near Clancy, Montana. Although the drainage area for the streamflow-gaging station on Prickly Pear Creek (192 square miles) is larger than that for Tenmile Creek near Rimini, the two watersheds were considered to be hydrologically similar based on similarity of recorded flow statistics.

Twenty dates between May 1 and October 31, 1997 were randomly selected for the test of reliability of monthly natural discharge estimates. For each ran- domly selected date, the daily mean discharge from the record at the streamflow-gaging station on Prickly Pear Creek was considered to be the measured or observed discharge used for regression with concurrent estimated natural daily discharge for Tenmile Creek near Rimini. The results of the regression indicate a strong relation between daily flows for the two sites (figure $15)$, especially for lower flows. The equation for the regression line shown in figure 15 then was used to calculate long-term mean monthly discharges for Prickly Pear Creek from the long-term mean monthly natural discharges for Tenmile Creek near Rimini. The calculated monthly means were compared with monthly means from the actual record for the period 1961-90 in figure 16. Estimation errors (percent differences between actual means and estimated means) ranged from -6.6 percent in February to 14.2 percent in August. Overall, the average error for estimated mean annual discharge at the Prickly Pear Creek site was 3.9 percent. Based on the test results of the streamflow correlation method, estimation errors for most flowestimation sites in the upper Tenmile Creek basin may be considered to be about the same or slightly larger then those for Prickly Pear Creek. Flow-estimation sites having small $\mathrm{R}^{2}$ and large $\mathrm{SE}$ are likely to have larger estimation errors than the test site. However, most sites having poor $\mathrm{R}^{2}$ and $\mathrm{SE}$ also had small monthly discharges; consequently, larger percent errors do not necessarily represent large flow volumes. 


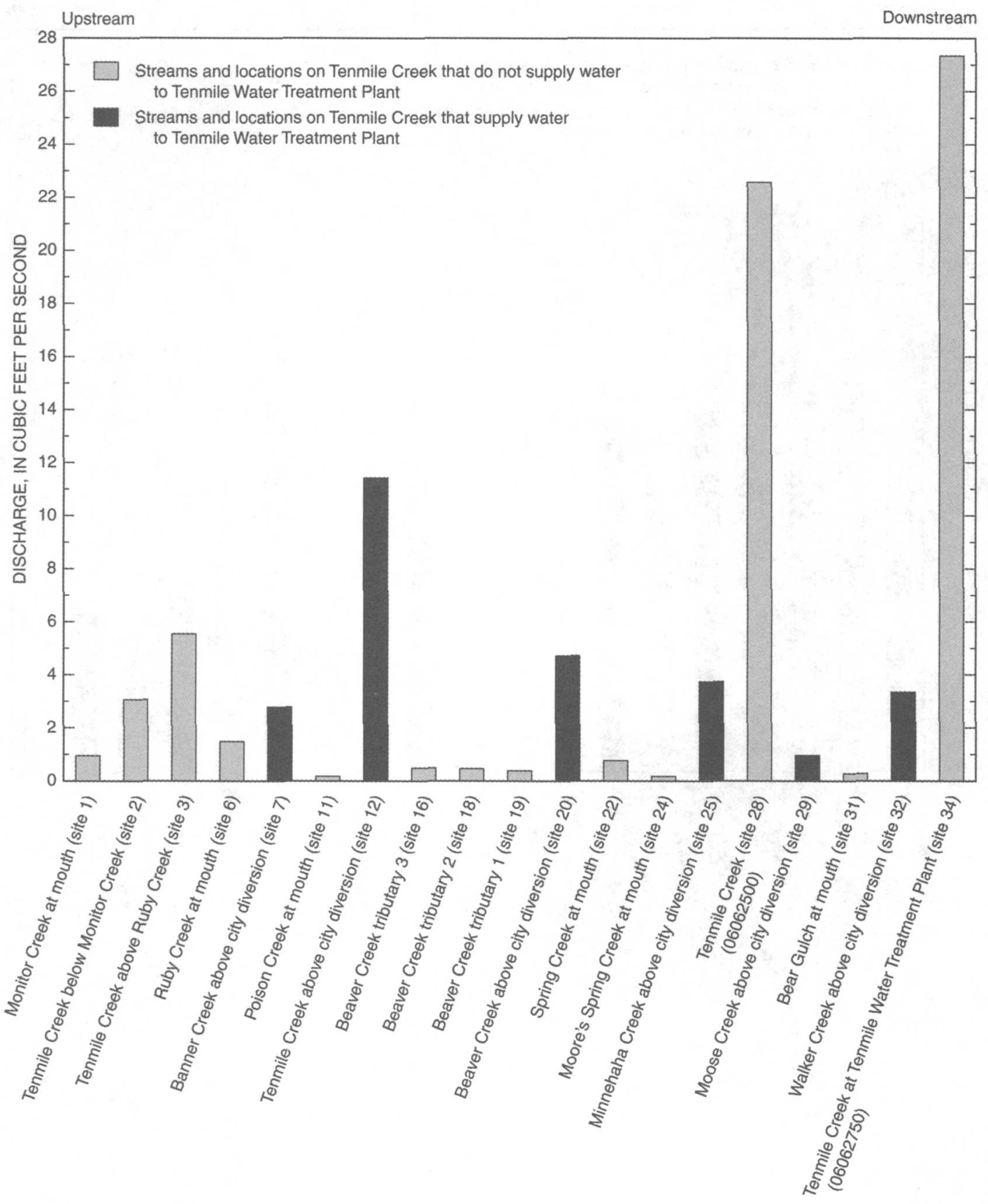

Figure 13. Estimated long-term annual natural discharge for streams in the upper Tenmile Creek watershed near Rimini, Montana.

\section{Determination of Gaining and Losing Stream Reaches on Tenmile Creek}

Diversions for the Tenmile Water Treatment Plant often dewater Tenmile Creek, particularly in Rimini from the Tenmile Creek diversion to the mouth of Spring Creek, a distance of about 0.5 mile. The elimination of existing diversion structures and replacement with a single mainstem diversion at the Tenmile Water Treatment Plant has been suggested to minimize mainstem dewatering caused by diversions. Although this kind of change in water management would alleviate dewatering problems, it might result in a loss of water available to the Tenmile Water Treatment Plant if significant flow losses occur in the channel between Rimini and the plant. 


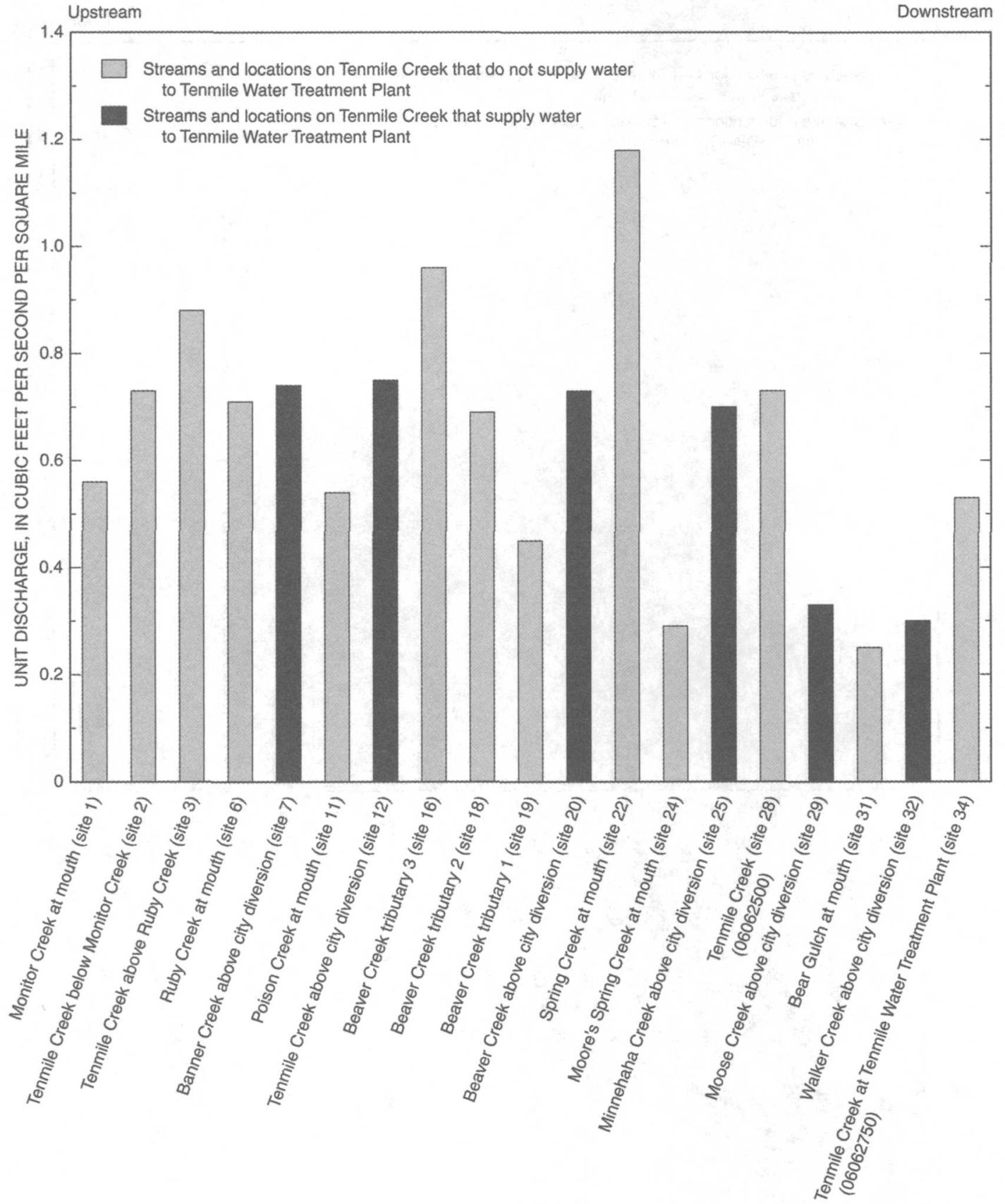

Figure 14. Estimated long-term annual unit natural discharge for streams in the upper Tenmile Creek watershed near Rimini, Montana.

To help determine whether such flow losses are evident, two series of synoptic discharge measurements at selected locations on Tenmile Creek were made during very low-flow conditions on September 6, 1998 and during slightly greater flow conditions on July 14, 1999. All measurements during each series were made over the course of a single day when flows at the gaging stations near Rimini (06062500) and the
Tenmile Water Treatment Plant (06062750) were relatively steady. For example, discharge at station 06062500 varied by only 0.1 cubic feet per second throughout the day on September 6,1998 and by only 0.2 cubic foot per second on July 14, 1999. Likewise, discharge at station 06062750 varied by 0.1 cubic foot per second throughout the day on September 6, 1998 and by about 0.4 cubic foot per second on July 14 , 


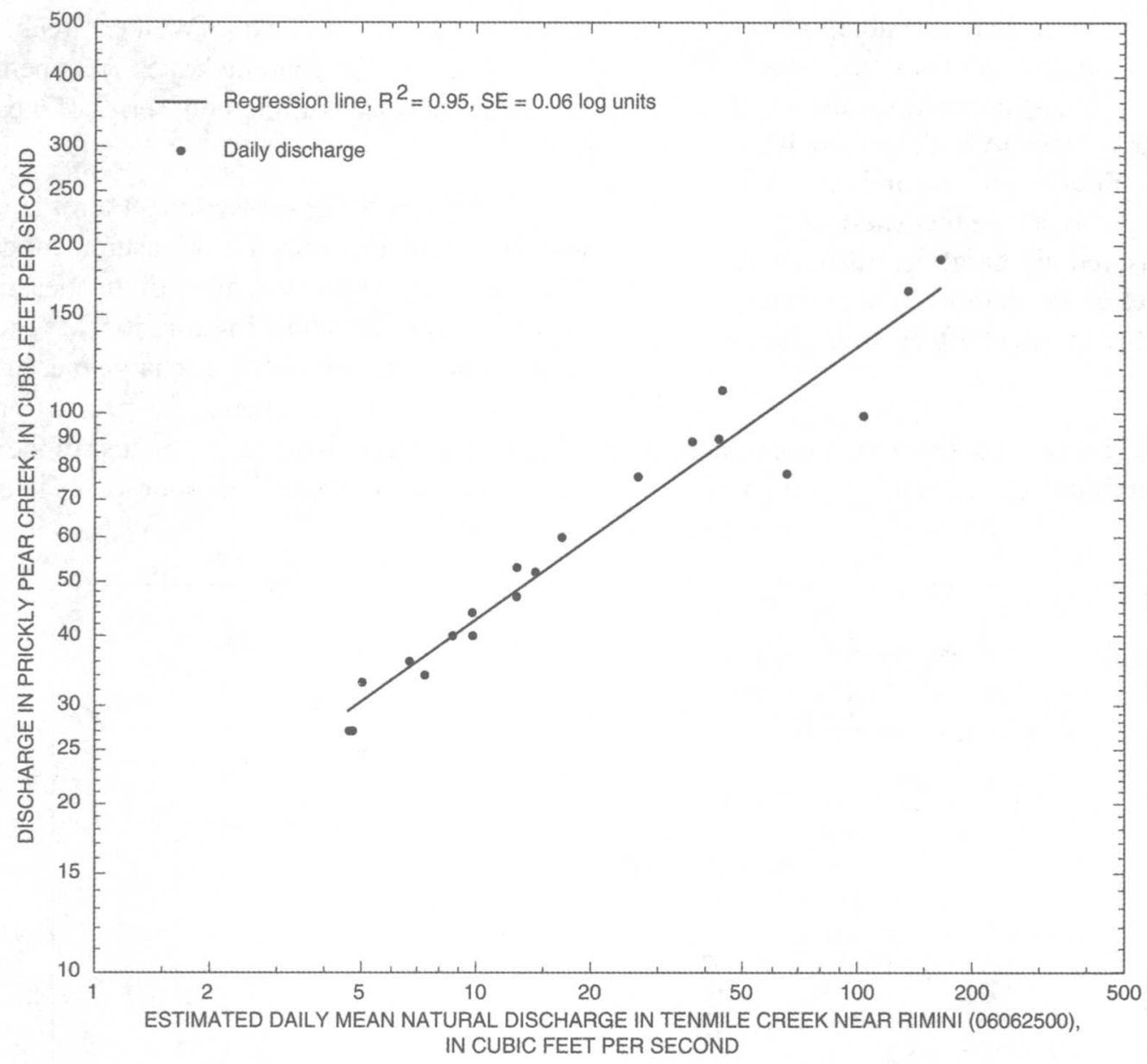

Figure 15. Regression relationship between selected daily mean discharge for Prickly Pear Creek (station 06061500) and estimated daily mean natural discharge for Tenmile Creek near Rimini (site 28), Montana.

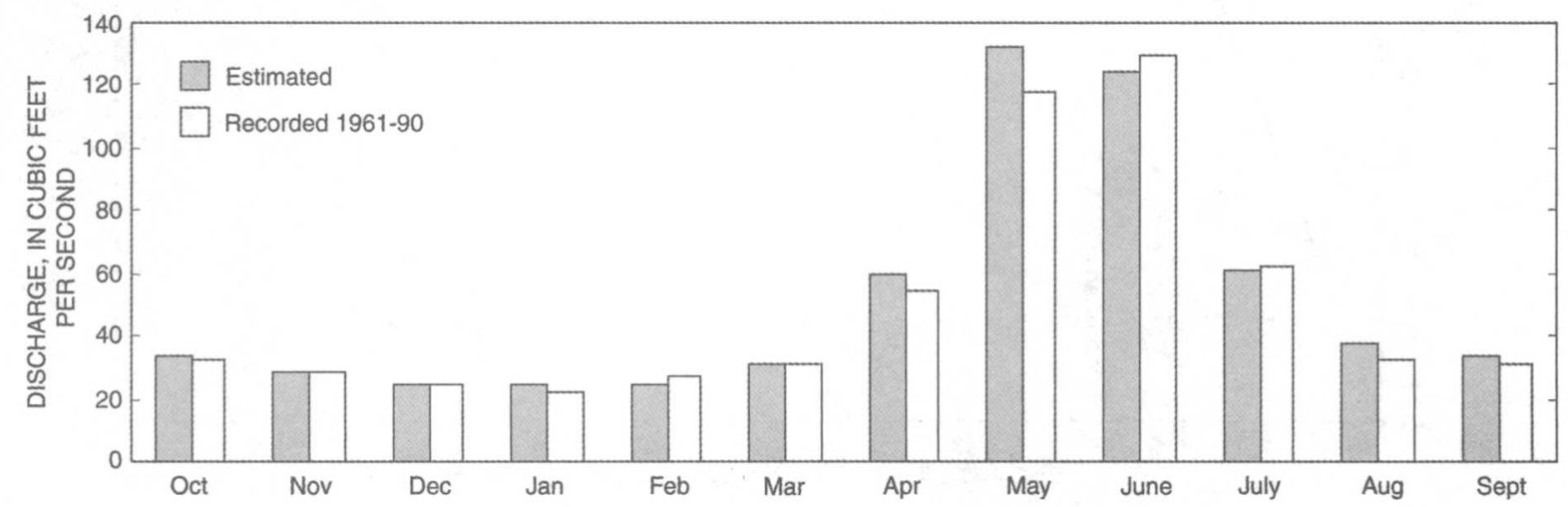

Figure 16. Comparison between estimated and recorded long-term mean monthly discharge for Prickly Pear Creek (station 06061500), Montana. 
1999. Except for Minnehaha Creek, which had an estimated discharge of less than 0.1 cubic foot per second, all tributary streams were dry on September 6, 1998. On July 14, 1999, Minnehaha Creek was dry, but Moose Creek and Walker Creek had small discharges. Steady flow conditions and minimal tributary inflows help to ensure that site-to-site differences in measured discharge are attributable to gains from or losses to the shallow ground water system and not to the transient effects of upstream flow changes.

Measured discharges at selected mainstem locations are plotted on figure 17. Discharge generally increased gradually downstream from the city diversion in Rimini to the mouth ofWalker Creek. From Walker Creek to the Tenmile Water Treatment Plant, discharge decreased during both series of measurements.

Estimates of the measurement error at each site also are plotted on figure 17. Measurement error was based on a subjective evaluation of the measuring conditions (channel and flow irregularities) at each site as noted on the hydrographer's discharge measurement note. For most measurements, the error was conservatively selected as \pm 10 percent. Because of the measurement error, apparent small gains or losses in discharge

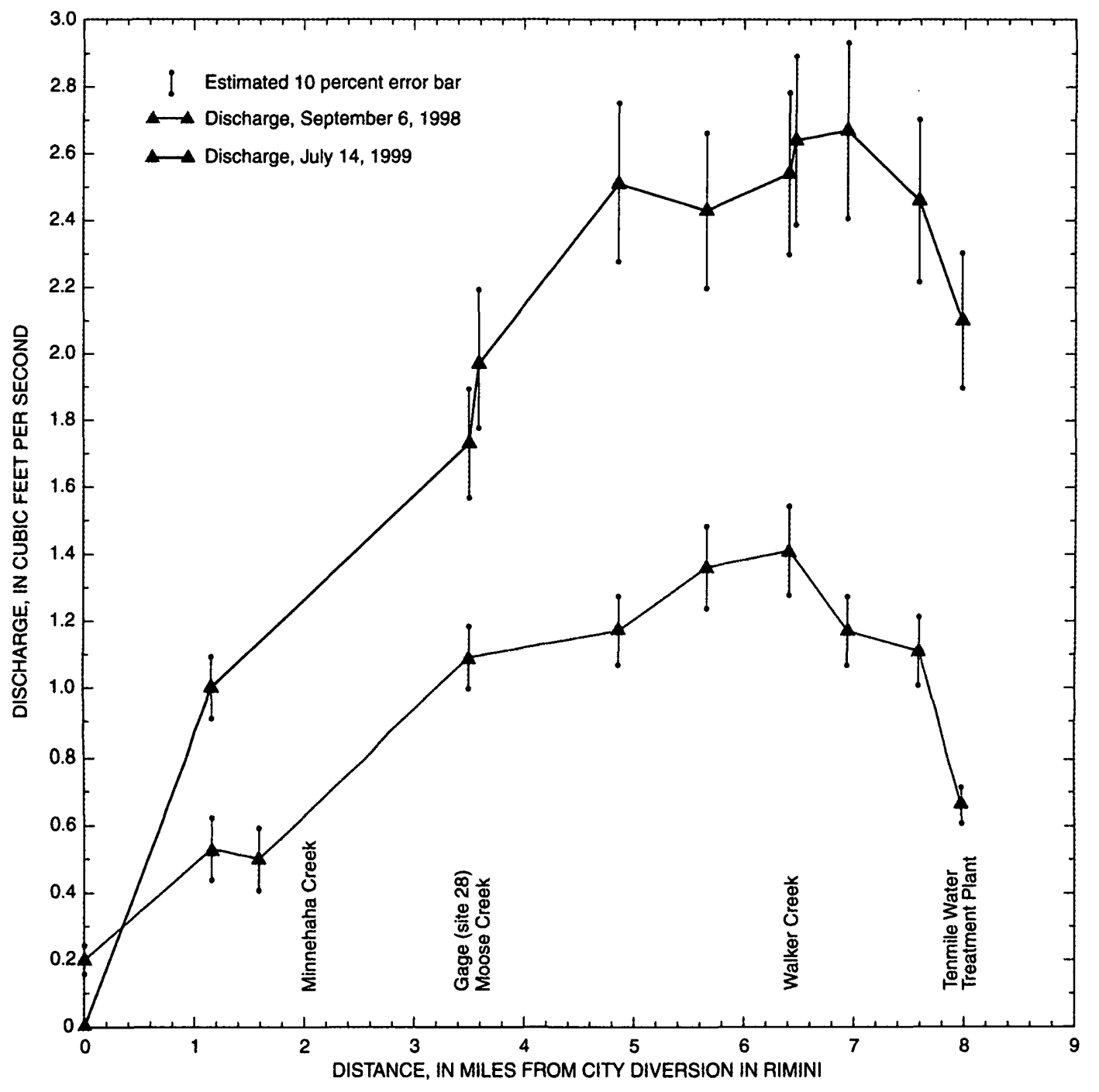

Figure 17. Measured discharge and estimated error, September 6, 1998, and July 14, 1999, Tenmile Creek, upper Tenmile.Creek watershed near Rimini, Montana. 
between adjacent sites shown in figure 17 may not be real if the value lies within the range of the adjacent error bar. However, the overall increase in discharge from the upstream end of the measurement reach at Rimini to the mouth of Walker Creek was greater than the error range during both series of measurements and signifies an actual gain in streamflow. Because this increase in discharge is greater than the inflows from tributaries, the gains are probably from ground water inflow. Therefore, the reach of Tenmile Creek from Rimini to Walker Creek can be characterized as a gaining reach. The overall decrease in discharge from Walker Creek to the Tenmile Water Treatment Plant also was greater than the error range during both series of measurements and indicates streamflow losses to the ground-water system (losing reach).

Overall, the difference in discharge between the uppermost site at Rimini and the Tenmile Water Treatment Plant was relatively small $\left(0.4 \mathrm{ft}^{3} / \mathrm{s}\right)$ on September 6, 1998, although this difference represents a threefold increase. On July 14, 1999 streamflow increased significantly $\left(2.1 \mathrm{ft}^{3} / \mathrm{s}\right)$ from the diversion in Rimini to the Tenmile Water Treatment Plant. This increase was substantially greater than the tributary inflows, indicating that streamflow gains in the reach between Rimini and Walker Creek generally are sufficient to offset losses in the reach between Walker Creek and the treatment plant. A tracer-injection study using sodium chloride, a conservative chemical tracer, provided general confirmation of gaining and losing reaches as described by the current meter discharge measurements (Thomas E. Cleasby, U.S. Geological Survey, oral commun., 2000).

\section{WATER-QUALITY}

Stream water was sampled over a wide range of flows and analyzed for various chemical constituents to gain an understanding of current water-quality conditions throughout the upperTenmile Creek watershed. In addition, samples of bottom sediment from Chessman Reservoir, a major source of municipal water supply, were analyzed for trace-metal concentrations. A description of sampling sites and potential sources of water-quality degradation, the strategy for sample collection and analysis, methods of sampling and analysis, quality assurance procedures, and a general discussion of results are presented in the following sections of the report.

\section{Strategy for Sample Collection and Analysis}

Stream water was sampled during May through October 1997 at 21 locations in the upper Tenmile Creek watershed. Samples were collected at multiple locations on Beaver Creek and Tenmile Creek, streams that provide most of the municipal water supply to the Tenmile Water Treatment Plant. In addition, sampling sites were selected at the mouths of major tributaries to Tenmile Creek (table 9). Most sites were sampled twice during high-flow conditions in May and June and twice during near base-flow conditions in August and October.

However, not all sites were sampled four times (table 9). Monitor Creek at mouth (site 1) could not be sampled in May and June because of difficult site access. Sampling at Tenmile Creek below Monitor Creek (site 2) was discontinued after June because preliminary laboratory analyses indicated that water quality was nearly identical to that just downstream at Tenmile Creek above Ruby Creek (site 3). Banner Creek above city diversion (site 7) could not be sampled in May because snow conditions prevented access. Banner Creek tributary (site 9) could not be sampled in May because of difficult site access and was sampled the only time it was found flowing during base-flow conditions in August. Tenmile Creek above city diversion (site 12) also could not be sampled in May because the stream could not safely be waded during the high flow. Nearby sites on Banner Creek (site 10) and Tenmile Creek (site 13) were substituted for sites 7 and 12 respectively during the May high flow because the magnitude of intervening diversions relative to the instream flows are negligible. Beaver Creek above tributary 3 (site 15) at the outlet of Chessman Reservoir was sampled only in August and October because no water from the reservoir was being released during sampling times in May and June.

During each of the four sampling episodes in May, June, August, and October, samples were collected within a 2- or 3-day period to minimize changes in water-quality resulting from changing weather and streamflow. Streamflow was determined at the time of sampling either by direct measurement or from a previously established stage-discharge relationship.

Water samples were analyzed for concentrations of major ions, nutrients, trace elements, and suspended sediment. Concentrations of trace elements likely to be associated with hard-rock mining and the naturally high metal content of the local rock formations were of 
special concern in this study. Thus, concentrations of the trace elements arsenic, cadmium, copper, lead, and zinc were analyzed both for the dissolved and totalrecoverable phases. Laboratory methods, minimum reporting levels, and water-quality standards for human health and aquatic life for the sampled constituents are presented in table 10 .

Copper sulfate, a chemical commonly added to water in Chessman Reservoir to retard algae growth in late summer, was considered a potential source of elevated copper concentrations in water released from Chessman Reservoir. Samples of bottom sediment from selected sites in and near the reservoir were analyzed for concentrations of arsenic, cadmium, chromium, copper, lead, and zinc to help determine whether the copper sulfate was accumulating in bottom sediments of Chessman Reservoir and whether trace elements other than copper might be present. One bottomsediment sampling site was located just upstream from the reservoir in a natural wetland area. This site, which is outside the area of copper sulfate application, was sampled to help determine if copper concentrations in bottom sediment in Chessman Reservoir were attributable to copper sulfate application to the reservoir or from natural sources upstream from the reservoir. The reporting limits for all trace elements was $0.001 \mathrm{mg} / \mathrm{L}$, with the exception of lead, which was $0.01 \mathrm{mg} / \mathrm{L}$.

\section{Methods of Sample Collection and Analysis}

Water and bottom-sediment samples were collected and analyzed using standard methods. Those methods are explained in the following sections.

\section{Water Sampling}

Water samples were collected by either depth integration at multiple stream verticals using methods described by Knapton (1985), Edwards and Glysson (1988), and Ward and Harr (1990), or by grab sampling at sites where streamflow was very small. Water temperature, $\mathrm{pH}$, and specific conductance were measured in the field according to standard methods described by the U.S. Geological Survey (1977) and Knapton (1985).

Depth-integrated samples were collected with a polyethylene DH-81 hand-held sampler with a nylon nozzle and composited in a polyethylene churn-splitter.
Suspended-sediment samples were collected in glass bottles using a DH-48 hand-held sediment sampler. Pre-processed samples were protected from atmospheric contamination by using a churn-splitter modified with a cappable funnel. The churn's exterior was protected using a large plastic container. Samples were handled using vinyl gloves that were frequently changed between sample collection, sample processing, and equipment decontamination. Bottles and equipment were prepared in the laboratory and samples were processed, filtered, and preserved in the field as described by Horowitz and others (1994).

Sample processing was completed using a processing chamber to reduce and eliminate potentially derived atmospheric inputs. All samples for dissolved trace metal analysis were passed through a 0.45 -micron filter to remove suspended material. Samples were processed and preserved using procedures described by Horowitz and others (1994).

Chemical analyses of water-quality samples were completed by Montana Tunnels, Inc. Aluminum, chromium, iron, manganese, nickel, silver, and zinc were analyzed by inductively coupled plasma spectroscopy. Arsenic, cadmium, copper, lead, and selenium were analyzed by graphite furnace atomic absorption. Mercury was analyzed by flow injection cold vapor/ hydride. Both graphite furnace atomic absorption and flow injection cold vapor/hydride were used to determine concentrations of arsenic in bottom sediment (U.S. Environmental Protection Agency, 1983). The Montana Tunnels Laboratory participated in a standard reference program and was certified by the USGS National Water Quality Laboratory (NWQL), Denver, Colo., for this project. The quality control and assurance methods used by the Montana Tunnels Laboratory are described in a Quality Assurance Manual (Montana Tunnels Mining, Inc., 1997).

Suspended-sediment samples were analyzed for concentration and particle-size distribution (percent finer than $0.062 \mathrm{~mm}$ diameter) by the USGS sediment laboratory in Helena, Montana. Methods and qualityassurance procedures used to analyze suspended sediment are described by Lambing and Dodge (1993).

\section{Bottom-sediment sampling}

Bottom-sediment samples were collected in varying water depths not exceeding $4 \mathrm{ft}$. Samples were collected using a BMH-53 hand-held, stainless steel 
coring device. To provide a composite sample at each site, several samples of bottom sediment were collected at locations several feet apart and added together. Two composited samples from different depths were obtained from one location (sites R2A and R2B) to determine whether trace-metal concentrations varied with depth. Samples were collected from the upper 9 in. of the bottom sediments and were composited using new, plastic kitchenware including a plastic spatula, a plastic spoon, and a rinsed white dishpan. Equipment was rinsed between samples using deionized water. Composited bottom-sediment samples were stored and shipped in plastic freezer bags. Samples were submitted to the NWQL for the determination of total traceelement concentrations in sediment.

Samples for trace-element analyses were air dried in the laboratory and then crushed and sieved through a 230 -mesh $(0.063-\mathrm{mm})$ nonmetal screen. The fraction of particles smaller than $0.063 \mathrm{~mm}$ was retained and analyzed using methods described in Severson and others (1987).

\section{Quality Assurance}

The effectiveness of quality-assurance practices is measured by quality-control data that document possible sample contamination and reproducibility of analytical results. These data were provided by test samples that consisted of a field-blank sample of deionized water or a replicate environmental sample incorporated into the routine sample sets submitted to the laboratory. A field-blank sample of deionized water is treated as an environmental sample in all aspects, including exposure to sampling equipment, sample containers, filtration apparatus, chemical preservatives in the field, holding times, and laboratory processing. A replicate environmental sample is a volume of sampled material split into subsamples in such a manner that the physical and chemical characteristics of each subsample are considered essentially identical in composition.

Quality-control samples comprised approximately 10 percent of the total number of water samples submitted for analysis. Quality-control samples for water-quality analyses consisted of two deionized water blanks and two replicates per sampling trip. Two replicate samples were analyzed by the NWQL to provide some comparison of analytical results from two independent laboratories.
Deionized water blanks should contain no detectable concentrations of analytes. If detectable concentrations occur, then the magnitude and persistence of the values need to be examined in order to evaluate the possible source of contamination and subsequent effect of bias in the overall database. When detection of an analyte occurs in a sample blank, it is necessary to evaluate the potential effect on the corresponding environmental sample results. In general, sample-blank concentrations that are twice the minimum reporting level or less are considered acceptable due to the limits of precision at the minimum range of the analytical method. Results for blank samples that are greater than twice the minimum reporting level indicate possible contamination introduced during either the sampling or analytical process. A one-time detectable, small concentration of an analyte is too random to isolate the source of contamination and will likely have little effect on the overall bias of the database. However, persistent occurrence of detectable concentrations in blanks for the same constituent indicates that bias may be widespread and the environmental data for that constituent may be questionable. If the detectable concentrations are both large and persistent, all data for that constituent are probably unreliable.

Measurable concentrations of some analytes were detected in deionized water blanks during the study. Zinc contamination of the field blanks was especially large and persistent. The concentration of dissolved zinc was $40 \mu \mathrm{g} / \mathrm{L}$ in the June field blank, and the concentration of total recoverable zinc was $100 \mu \mathrm{g} / \mathrm{L}$ in the August field blank. Complicating this occurrence of contamination indicated by high zinc concentrations in field blanks was the fact that several environmental samples had zinc concentrations below detection levels. Thus, the contamination occurred in a very irregular pattern.

A suite of blank samples was prepared and analyzed in October 1997 to determine whether the sporadic zinc contamination could be associated with the sample collection bottles or the acid used to preserve water-quality samples. Five blank samples were prepared using a combination of sample bottles and preservatives from both the routine supplier used during the study and from the NWQL. Two samples preserved with nitric acid preservative from the routine supplier had zinc concentrations of 10 and $70 \mu \mathrm{g} / \mathrm{L}$, while samples preserved with nitric acid preservative provided by the NWQL were free of detectable concentrations of zinc. 
Based on these tests, it was determined that the vials of nitric acid preservative contained variable, but consistently measurable quantities of zinc and were responsible for the contamination of the blanks. The persistent and variable magnitude of contamination in field blanks makes the zinc concentrations in environmental samples questionable. In particular, zinc concentrations in environmental samples that were less than the maximum concentration found in any field blank $(100 \mu \mathrm{g} / \mathrm{L})$ may be unreliable. Therefore, the minimum reporting level for zinc concentration for this study was revised upward from $10 \mu \mathrm{g} / \mathrm{L}$ to $100 \mu \mathrm{g} / \mathrm{L}$ to reflect the loss of resolution in the range affected by contamination. Zinc concentration data were not used to calculate zinc loads, or to make comparisons between sites.

Copper, sodium, potassium, and magnesium were sporadically found in field blank samples at concentrations slightly greater than twice the minimum reporting level. Each constituent was found in only one monthly sampling; therefore, the low concentration and single occurrence of each was considered to have no significant effect on the environmental data.

\section{Sampling Sites and Potential Sources of Water-Quality Degradation}

Sampling sites were selected to provide broad spatial coverage of streams throughout the upperTenmile Creek watershed (table 9). Sites for localized characterization were also selected downstream from inactive mines and waste-rock piles that were potential sources of trace elements in water. The sites and potential sources of water-quality degradation are described in the next section.

\section{Headwaters Sampling Sites}

Six sampling sites in the headwaters of Tenmile Creek were located on Monitor Creek at mouth (site 1), Tenmile Creek below Monitor Creek (site 2), Tenmile Creek above Ruby Creek (site 3), Ruby Creek at mouth (site 6), Banner Creek above city diversion (site 7), and Banner Creek below city diversion (site 10). Most of this part of the basin is public land managed by the U.S. Forest Service, Helena National Forest. Under the current forest plan, commercial logging activity is restricted because the basin supplies municipal water for Helena. Mine wastes associated with the Monitor
Creek Tailings, the SE SE S13 Mine, the Monte Cristo Mine, the Peter Mine, the Woodrow Wilson Mine, the Peerless Jenny/King Mine, and the Queensbury Mine (fig. 1), are potential sources of trace elements in water in the headwaters area.

\section{Sampling Sites near Rimini}

Six sampling sites were located near the historic mining town of Rimini in the central portion of the upper watershed. A substantial amount of mining took place near Rimini at the Lee Mountain Mine, the Red Water Mine, the Tenmile Mine, the Red Mountain Mine, the Upper Valley Forge Mine, and the Valley Forge/Susie Mine (fig. 1).

Poison Creek (site 11), a small, perennial tributary to Tenmile Creek, originates from a spring on the west flank of Red Mountain. It was considered a likely source of trace elements to Tenmile Creek because the stream flows through waste rock piles at the Red Mountain Mine site.

Tenmile Creek above city diversion (site 12) is located at Rimini and is downstream from the Red Water and Tenmile Mine sites. Water-quality conditions at site 12 indicate the quality of water withdrawn from Tenmile Creek for municipal use as a drinkingwater supply for Helena. Water-quality conditions for Tenmile Creek below city diversion (site 13) were presumed to be identical to those for site 12 . Water quality was sampled once from the bridge at site 13 rather than at site 12 because site 12 , which has no bridge, could not be waded during high flow.

Spring Creek (site 22) is a small perennial stream that provides a relatively constant source of inflow to Tenmile Creek in the town of Rimini. Site 22 is below several small, unnamed mine sites. Tenmile Creek below Spring Creek (site 23) is in the middle of the residential area of Rimini and below discharges emanating from mine adits (entrances) at the Lee Mountain Mine andValley Forge/Susie Mine.

\section{Sampling Sites in the Beaver Creek Drainage}

Three sampling sites were located in the Beaver Creek drainage. Beaver Creek above tributary 3 (site 15 ) is just below Chessman Reservoir and provides an indication of the quality of water released from the reservoir. Beaver Creek tributary 2 (site 18) drains the basin that includes the National Extension Mine site. Beaver Creek above city diversion (site 20) is several 
hundred feet upstream from the municipal diversion near the mouth of Beaver Creek and provides an indication of the quality of water withdrawn from Beaver Creek for municipal use.

\section{Sampling Sites between Rimini and the Tenmilo Water Treatment Plamt}

Six sampling sites were located between Rimini and the Tenmile Water Treatment Plant. Minnehaha Creek was sampled above the municipal diversion near the mouth (site 25). This site, which is downstream from the Beatrice, Justice, and Armstrong Mines, provides an indication of the quality of water withdrawn from Minnehaha Creek for municipal use.

Tenmile Creek near Rimini (site 28), the location of the long-term USGS streamflow-gaging station, was sampled to provide water-quality information for Tenmile Creek near the center of the upper Tenmile Creek watershed. From Rimini to site 28 just below Moose Creek, Tenmile Creek closely parallels the main county road to Rimini, a potential source of sediment runoff to the stream.

Moose Creek above city diversion (site 29) drains an area with no historical mining activity and, thus, probably represents background water-quality conditions. Moose Creek also supplies some municipal water for Helena.

Bear Gulch was sampled at its mouth (site 31). Although this tributary stream is small and flows intermittently, it drains the basin that includes the Bear Gulch mine site.

The sampling site Walker Creek above city diversion (site 32 ) provides an indication of the quality of water withdrawn from this tributary stream for municipal use. Walker Creek is the only sampled stream that drains primarily agricultural and rural residential land at lower elevations of the watershed.

The sampling site Tenmile Creek at Tenmile Water Treatment Plant (site 34) is the watershed outlet. Water-quality conditions at this site represent the cumulative, integrated effects of all land uses in the watershed.

\section{Bottom-Sediment Sites in and near Chessman Reservoir}

Five composited samples of bottom sediment were collected from three locations in Chessman Reservoir and one location just upstream from the reservoir on September 8, 1997. Sites were located where varia- tions in trace-metal concentrations might be expected from different reservoir inflow conditions or from reservoir dredging associated with dam rehabilitation in 1986. Sampling locations are listed in Table 11 and shown in figure 1.

The sampling site Chessman Reservoir Southwest (site R1) was located in a dredged area about 1015 feet offshore near the inlet of the Banner Creek flume. The sampling location Chessman Reservoir Northeast (sites R2A and R2B) was about 10-15 feet offshore and outside the area dredged in 1986. The sampling site Wetland above Chessman Reservoir (site R3) was upstream from the high-water mark of the reservoir in a wetland area drained by the headwaters of Beaver Creek. Bottom-sediment samples at site R3 were collected from the banks and bottom of Beaver Creek at a site close to streamflow-estimation site 14 . The sampling site Chessman Reservoir Southeast (site R4) was located about 10-15 feet offshore and about 40-50 feet from the confluence of Beaver Creek and the reservoir.

\section{Results of Water-Quality Analyses}

Diverse land uses, geology, stream basin size, and seasonal climatic fluctuations play a role in determining current water-quality characteristics in the upper Tenmile Creek watershed. Water quality generally varies from the relatively pristine water in Moose Creek to water having relatively high concentrations of trace elements downstream from mines or mine wastes. Table 12, at the back of the report, contains water-quality results for field-measured parameters, major ions, and nutrients. Table 13, at the back of the report, presents results for trace elements and suspended sediment. Quality-control data (results for replicates and blanks) are presented with environmental sample results in tables 12 and 13 . The results are described in more detail in the following sections of the report.

\section{Field-Measured Parameters, Major lons, and Nutrients}

Specific conductance, a field-measured parameter that generally indicates the relative abundance of dissolved minerals in water, ranged from $3.0 \mu \mathrm{S} / \mathrm{cm}$ in Banner Creek below city diversion (site 10) to 231 $\mu \mathrm{S} / \mathrm{cm}$ in Poison Creek (site 11). Values for $\mathrm{pH}$, a fieldmeasured parameter that indicates relative acidity of water, ranged from 3.8 (highly acidic) in Poison Creek (site 11) to 8.2 (slightly basic) in Walker Creek (site 32). 
Surface water in the upper Tenmile Creek watershed generally is a calcium bicarbonate type. Hardness, as $\mathrm{CaCO}_{3}$, ranged from $9 \mathrm{mg} / \mathrm{L}$ in Ruby Creek (site 6) to $82 \mathrm{mg} / \mathrm{L}$ in Bear Gulch (site 31).

Concentrations of the major ions calcium, magnesium, sodium, potassium, chloride, fluoride, and bicarbonate plus carbonate (alkalinity) generally were low throughout the upper watershed. Calcium concentrations ranged from $2.3 \mathrm{mg} / \mathrm{L}$ in Spring Creek at mouth (site 22) to $26 \mathrm{mg} / \mathrm{L}$ in Bear Gulch (site 31). Magnesium concentrations ranged from $<0.1 \mathrm{mg} / \mathrm{L}$ in Ruby Creek (site 6) and Spring Creek (site 22) to 6.3 $\mathrm{mg} / \mathrm{L}$ in Tenmile Creek below Spring Creek (site 23). Sodium concentrations ranged from $0.7 \mathrm{mg} / \mathrm{L}$ in Ruby Creek (site 6) to $8.4 \mathrm{mg} / \mathrm{L}$ in Walker Creek (site 32). Potassium concentrations ranged from $<0.1 \mathrm{mg} / \mathrm{L}$ in Ruby Creek (site 6) to $2.8 \mathrm{mg} / \mathrm{L}$ in Moose Creek (site 29). Chloride concentrations ranged from $0.5 \mathrm{mg} / \mathrm{L}$ at Tenmile Creek at Tenmile Water Treatment Plant (site 34) to $7.7 \mathrm{mg} / \mathrm{L}$ in Walker Creek (site 32), with 19 of the 21 sites having chloride concentrations of $<1.0 \mathrm{mg} / \mathrm{L}$. The lowest chloride concentration was for a replicate sample analyzed by the NWQL; this laboratory analyzes for a lower detection limit for chloride than does the Montana Tunnels Laboratory. Fluoride concentrations ranged from $<0.10$ to $0.68 \mathrm{mg} / \mathrm{L}$, with detectable concentrations reported from Monitor, Ruby, Banner, Poison, Beaver, Tenmile and Walker Creeks (sites 1, 3, 6, 9, 11, 18, 20, 23, 28, 32). Alkalinity, which primarily represents the combined acidneutralizing capacity of bicarbonate plus carbonate ions, ranged from $6 \mathrm{mg} / \mathrm{L}$ in several streams to $71 \mathrm{mg} / \mathrm{L}$ in Moose Creek (site 29).

Concentrations of another major ion, sulfate, reflect the presence of oxidizing sulfide minerals associated with mined, metalliferous ore deposits. Several sites in the upper Tenmile Creek watershed had sulfate concentrations greater than $25 \mathrm{mg} / \mathrm{L}$. Samples from Poison Creek (site 11) had sulfate concentrations between 55 and $94 \mathrm{mg} / \mathrm{L}$, with the highest value occurring during low-flow conditions in August. The highest sulfate concentration, $99 \mathrm{mg} / \mathrm{L}$, was for the August sample from Tenmile Creek below Spring Creek (site 23). Sulfate concentrations in Tenmile Creek in August decreased downstream from site 23 to $32 \mathrm{mg} / \mathrm{L}$ at Tenmile Creek near Rimini (site 28) and 26 $\mathrm{mg} / \mathrm{L}$ at Tenmile Creek at the Tenmile Water Treatment Plant (site 34). Bear Gulch (site 31) had sulfate concentrations of $30 \mathrm{mg} / \mathrm{L}$ and $36 \mathrm{mg} / \mathrm{L}$ in August and October, respectively. Other sites in the watershed had measurable concentrations of sulfate ranging from 2.1 to $17 \mathrm{mg} / \mathrm{L}$.

Concentrations of the nutrients (nitrite, nitrate, ammonia, total phosphorus, and dissolved orthophosphate) were very low in all samples collected in the upper Tenmile Creek watershed. Dissolved nitrite was detected in only one sample, Tenmile Creek below Spring Creek (site 23), at a concentration of $0.02 \mathrm{mg} / \mathrm{L}$ in October. Nitrate concentrations ranged from $<0.01$ to $0.12 \mathrm{mg} / \mathrm{L}$ for all samples but one from Banner Creek tributary (site 9) that had a concentration of 0.36 $\mathrm{mg} / \mathrm{L}$. Ammonia concentrations were less than or near the reporting limit of $0.05 \mathrm{mg} / \mathrm{L}$ for all samples. The concentration of total phosphorus ranged from $<0.01$ to $0.16 \mathrm{mg} / \mathrm{L}$, and the concentration of dissolved orthophosphate ranged from $<0.01$ to $0.05 \mathrm{mg} / \mathrm{L}$.

\section{Trace Elements}

Trace-element concentrations varied widely throughout the upper Tenmile Creek watershed. Very low trace-element concentrations generally were found in the headwaters streams Monitor Creek (site 1), Ruby Creek (site 6), Banner Creek (sites 7 and 10), and in Tenmile Creek above city diversion (site 12). Several Tenmile Creek tributaries, including Moose Creek (site 29), Bear Gulch (site 31), and Walker Creek (site 32), also had generally low concentrations of trace elements.

Trace-element concentrations were consistently high at sampling sites located downstream from mines or mine waste rock. Specifically, Poison Creek (site 11), located below the Red Mountain Mine; Beaver Creek tributary 2 (site 18), located below the National Extension Mine; and Tenmile Creek below Spring Creek (site 23), located below discharges from the Valley Forge/Susie Mine adit, all had high trace-element concentrations. These mines and their waste rock appear to provide a continuous source of trace elements to streams in the upper Tenmile Creek watershed. Analytical results for selected trace elements are described in detail below. Unless stated otherwise, results are for total-recoverable concentrations. Spatial and seasonal variations in concentrations are shown graphically for arsenic, cadmium, copper, and lead. Concentrations of these trace elements exceeded aquatic life and humanhealth standards for some samples (indicated in table 13). Concentrations of iron and manganese also exceeded drinking-water aesthetic standards for some samples. Graphs for these trace elements are not 
shown. For plotting purposes, concentrations of trace elements that were less than the analytical detection limits were shown as one-half the detection limits. Also for plotting purposes, concentrations for replicate samples were averaged.

\section{Aluminum}

The highest concentrations of total-recoverable aluminum were analyzed in samples from Poison Creek (site 11), ranging from $1,700 \mu \mathrm{g} / \mathrm{L}$ in October to $2,400 \mu \mathrm{g} / \mathrm{L}$ in June. Large concentrations of aluminum, ranging from $310 \mu \mathrm{g} / \mathrm{L}$ in October to $1,200 \mu \mathrm{g} / \mathrm{L}$ in August, also were found in samples from Tenmile below Spring Creek (site 23). Aluminum concentrations were greater during runoff conditions than during low-flow conditions at most sites. Natural erosion during runoff probably accounts for the greater concentrations in May and June because aluminum is common in soils and rocks. Because water-quality standards exist only for dissolved aluminum, an evaluation of exceedances is not possible for this element.

\section{Arsenic}

The spatial and seasonal variations in arsenic concentration for selected sites representing a diverse spatial distribution are depicted graphically in figure 18. Sites shown in figure 18 are Tenmile Creek above Ruby Creek (site 3); Poison Creek at mouth (site 11); Tenmile Creek above city diversion (site 12); Beaver Creek tributary 2 (site 18); Beaver Creek above city diversion (site 20); Tenmile Creek below Spring Creek (site 23); Minnehaha Creek above city diversion (site 25); Tenmile Creek near Rimini (site 28); Moose Creek above city diversion (site 29), and Tenmile Creek at Tenmile Water Treatment Plant (site 34). These sites are also included in figures 19-21 for other selected trace elements.

As shown in figure 18, concentrations of totalrecoverable arsenic were significantly greater during the May and June high-flow conditions than during low-flow conditions at Beaver Creek tributary 2 (site 18), and, for May, Poison Creek (site 11) and Beaver Creek above city diversion (site 20). Greater concentrations of arsenic during high-flow conditions probably indicate that the arsenic sources are mine-waste sediments that are mobilized by runoff. The largest concentration of arsenic during runoff conditions, 180 $\mu \mathrm{g} / \mathrm{L}$, was in the May sample from Poison Creek.
Arsenic concentrations were significantly larger during low-flow conditions than during runoff conditions at several sites. Most notably, large concentrations of arsenic were found in August and October at Tenmile Creek below Spring Creek (site 23) (170 and $63 \mu \mathrm{g} / \mathrm{L}$, respectively). The large arsenic concentrations at this site presumably resulted from inputs below the city diversion at Rimini (site 12), because concentrations were not elevated at site 12 . The effect of those arsenic inputs persisted downstream in Tenmile Creek where concentrations, although progressively diluted, remained relatively large in both August and October at Tenmile Creek near Rimini (site 28) (30 and $27 \mu \mathrm{g} / \mathrm{L}$, respectively), and at Tenmile Creek at the Tenmile Water Treatment Plant (site 34) (19 and $19 \mu \mathrm{g} / \mathrm{L}$, respectively). The sources of arsenic for these large measured concentrations probably are discharges from the adits at Lee Mountain andValley Forge/Susie Mines in Rimini. Because the mine-adit discharges are relatively constant year-round, concentrations of arsenic in Tenmile Creek presumably increase as streamflow, and hence dilution, decreases.

\section{Cadmium}

The spatial and seasonal variation in cadmium concentration for selected sites is depicted graphically in figure 19. As indicated in figure 19, Poison Creek (site 11) had uniformly high concentrations of totalrecoverable cadmium, ranging from 25 to $30 \mu \mathrm{g} / \mathrm{L}$ for the four samples. Tenmile Creek below Spring Creek (site 23) had concentrations of total-recoverable cadmium ranging from $1.0 \mu \mathrm{g} / \mathrm{L}$ in May to $30 \mu \mathrm{g} / \mathrm{L}$ in August. As was the case for arsenic, the large cadmium concentration in August represents the limited flow available in Tenmile Creek to dilute the relatively constant discharge from the mine adits. Beaver Creek tributary 2 (site 18 ) had a total-recoverable cadmium concentration of $6 \mu \mathrm{g} / \mathrm{L}$ in June, probably representing runoff-associated transport of mine wastes. Totalrecoverable cadmium values for all other sites ranged from $<0.1 \mu \mathrm{g} / \mathrm{L}$, the detection limit, to $2.8 \mu \mathrm{g} / \mathrm{L}$ during the study period.

\section{Copper}

The spatial and seasonal variation in copper concentration for selected sites is shown graphically in figure 20. Figure 20 shows that copper concentrations were consistently high in Poison Creek (site 11) during both runoff and low-flow conditions. Concentrations 


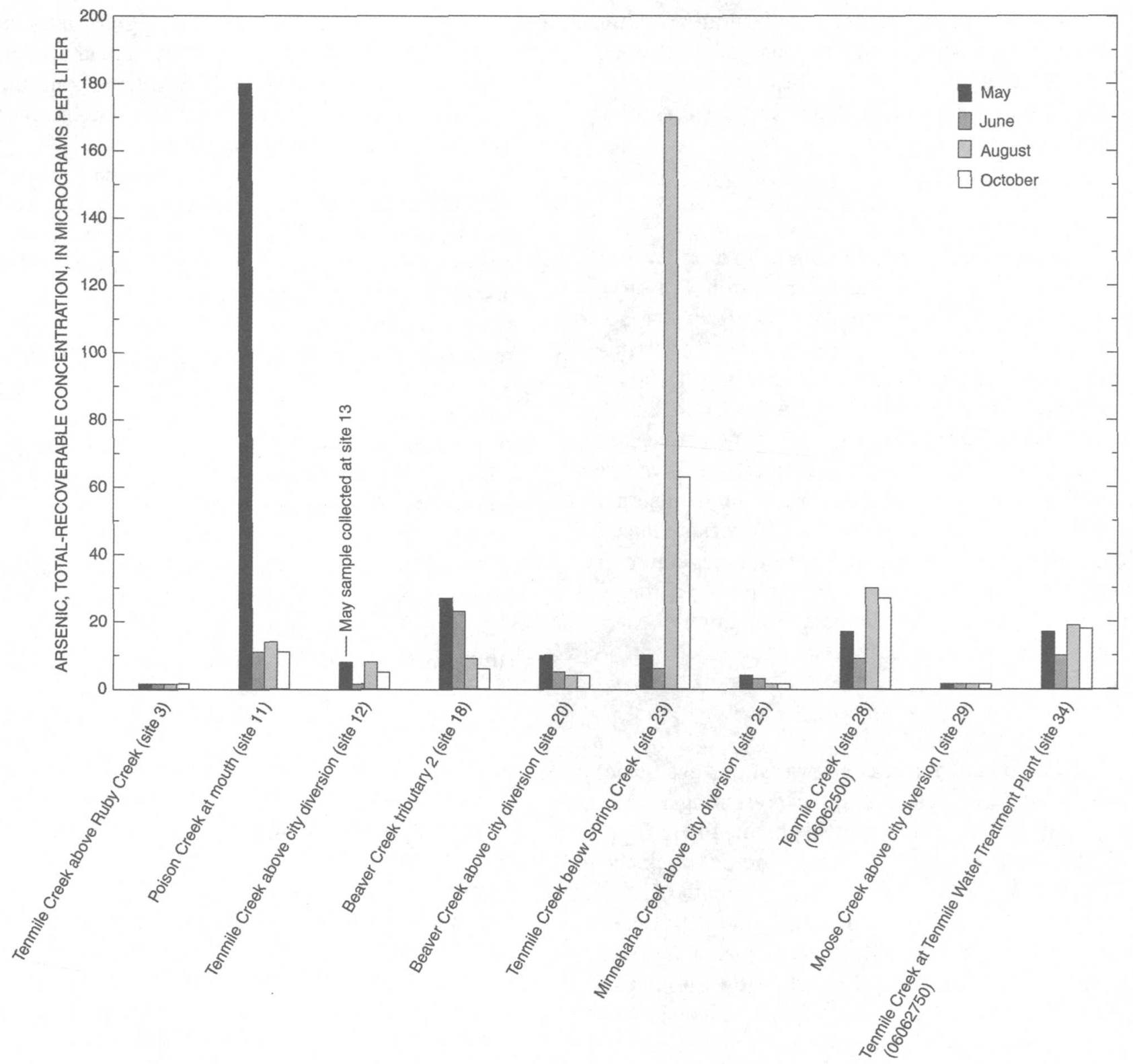

Figure 18. Total-recoverable arsenic concentrations in 1997 for selected sites in the upper Tenmile Creek watershed near Rimini, Montana.

were variably elevated in Tenmile Creek below Spring Creek (site 23) in May and October, and in Beaver Creek above city diversion (site 20) in October. Copper concentrations were less variable and generally low in Tenmile Creek above Ruby Creek (site 3) and above city diversion (site 12), Minnehaha Creek, and Moose Creek (site 29).

Consistently high copper concentrations, presumably associated with mine wastes, were found in Poison Creek (site 11), where concentrations ranged from 240 to $420 \mu \mathrm{g} / \mathrm{L}$. Total-recoverable concentrations at Tenmile below Spring Creek (site 23) were seasonally variable and ranged from 11 to $200 \mu \mathrm{g} / \mathrm{L}$. The elevated concentration of copper in Tenmile Creek below Spring Creek in August probably was not the result of tributary inflow from Beaver Creek because all flow in Beaver Creek was diverted for municipal use, but rather from inputs downstream from Beaver Creek. High concentrations of copper at Tenmile Creek below Spring Creek (site 23) also resulted in ele- 


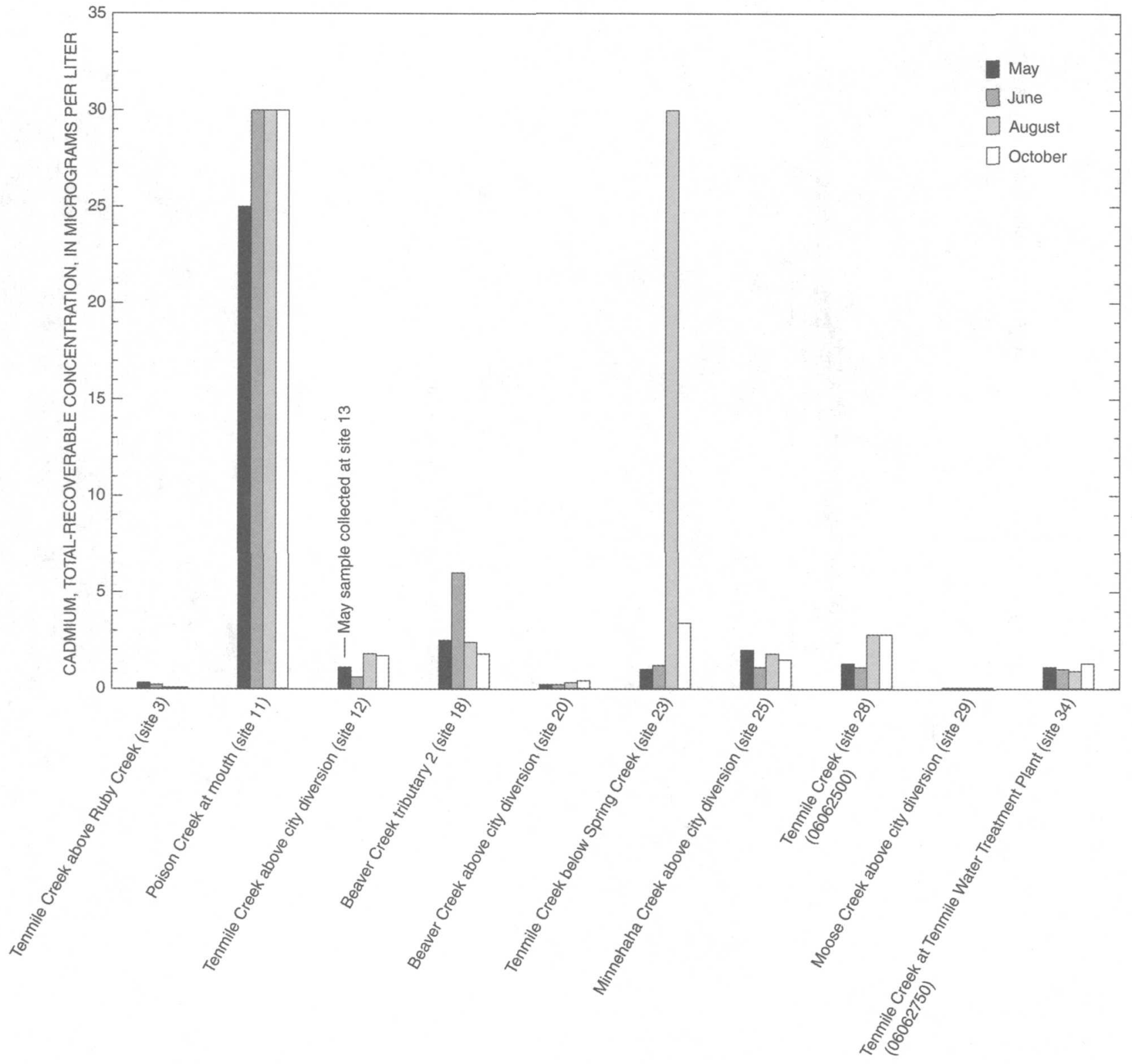

Figure 19. Total-recoverable cadmium concentrations in 1997 for selected sites in the upper Tenmile Creek watershed near Rimini, Montana.

vated mainstem concentrations downstream as far as the Tenmile Water Treatment Plant. Concentrations of total-recoverable copper ranged from 17 to $88 \mu \mathrm{g} / \mathrm{L}$ at Tenmile Creek near Rimini (site 28) and from 8 to 51 $\mu \mathrm{g} / \mathrm{L}$ at Tenmile Creek at the Tenmile Water Treatment Plant (site 34). Relatively large total-recoverable copper concentrations at Beaver Creek tributary 2 (site 18) in May and June (53 and $49 \mu \mathrm{g} / \mathrm{L}$, respectively) are likely related to runoff from mine waste areas.
High total-recoverable copper concentrations, ranging from $150 \mu \mathrm{g} / \mathrm{L}$ in August to $430 \mu \mathrm{g} / \mathrm{L}$ in October, also were found in Beaver Creek above tributary 3 (site 15, not plotted). As previously described, these high concentrations may be the result of the annual summer application of copper sulfate to Chessman Reservoir for algae-control purposes. Total-recoverable copper concentration in Beaver Creek above city diversion (site 20) also was high in October $(240 \mu \mathrm{g} / \mathrm{L})$. 


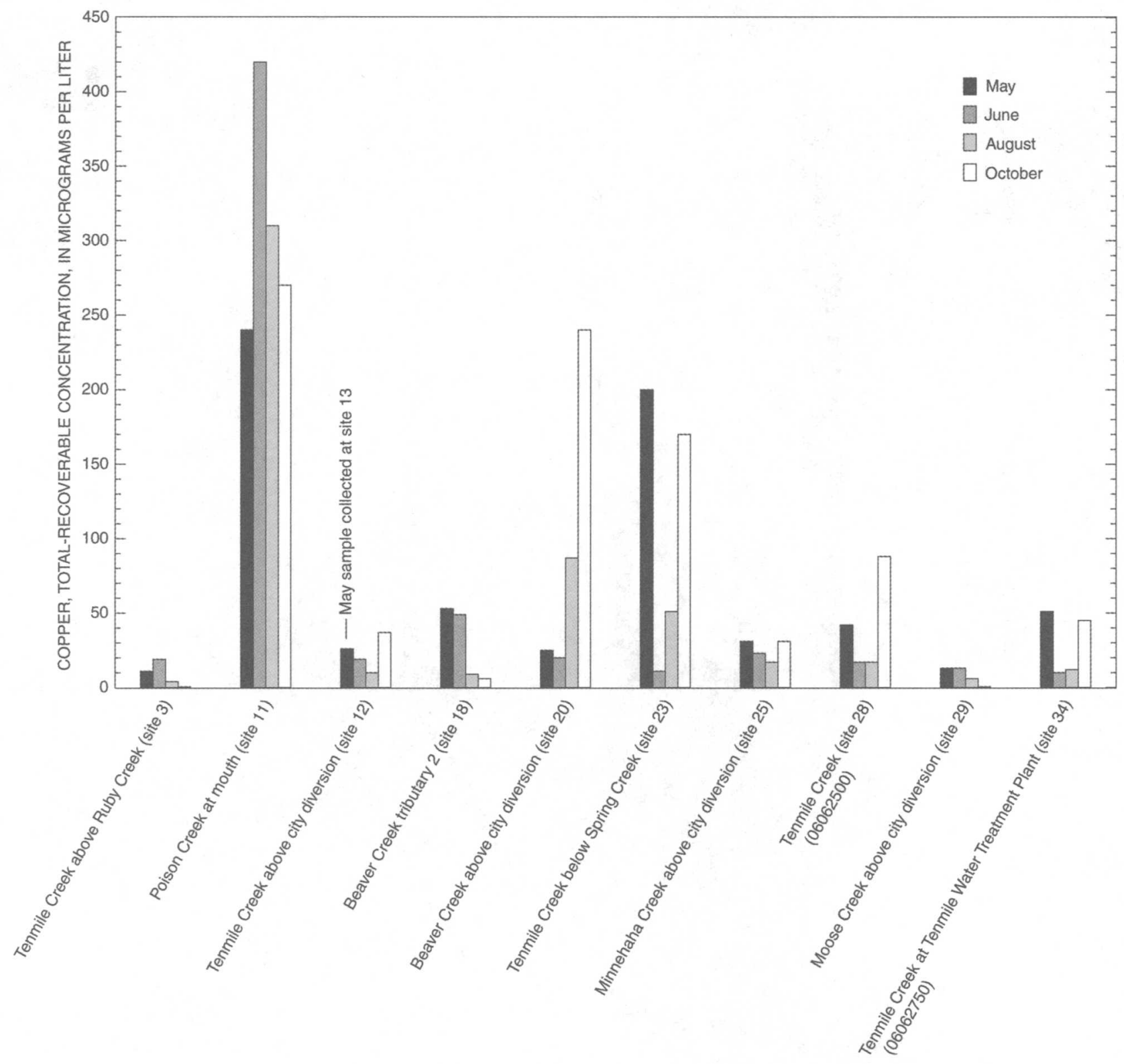

Figure 20. Total-recoverable copper concentrations in 1997 for selected sites in the upper Tenmile Creek watershed near Rimini, Montana.

This high value is attributable to water releases from Chessman Reservoir and not Beaver Creek tributary 2 (site 18), which had a total-recoverable copper concentration of only $6 \mu \mathrm{g} / \mathrm{L}$ in October.

Iron

Iron concentrations varied dramatically from high-flow to low-flow conditions. During spring runoff in May, concentrations were highest in samples from Poison Creek (site 11), 1,600 $\mu \mathrm{g} / \mathrm{L}$, and Banner
Creek below city diversion (site 10), 1,100 $\mu \mathrm{g} / \mathrm{L}$. The next largest iron concentration during May was 680 $\mu \mathrm{g} / \mathrm{L}$ for Bear Gulch at mouth (site 31). During lowflow conditions in August, large iron concentrations were found in samples from Beaver Creek above tributary 3 (site 15; 3,100 $\mu \mathrm{g} / \mathrm{L}$ ), Tenmile Creek below Spring Creek (site 23; 3,800 $\mu \mathrm{g} / \mathrm{L}$ ), and Walker Creek above city diversion ( same sites, iron concentrations in October were 730 $\mu \mathrm{g} / \mathrm{L}, 1,300 \mu \mathrm{g} / \mathrm{L}$, and $1,800 \mu \mathrm{g} / \mathrm{L}$, respectively. 
Lead

Spatial and seasonal variations in lead concentration for selected sites are shown graphically in figure 21. As shown in figure 21, total-recoverable lead concentrations generally were highest in Poison Creek (site 11), ranging from $52 \mu \mathrm{g} / \mathrm{L}$ in June to $140 \mu \mathrm{g} / \mathrm{L}$ in May. Beaver Creek tributary 2 (site 18) had concentrations which ranged from the detection limit $(<3 \mu \mathrm{g} / \mathrm{L})$ in October to $33 \mu \mathrm{g} / \mathrm{L}$ in May. Tenmile Creek below
Spring Creek (site 23) had high total-recoverable lead concentrations ranging from $8 \mu \mathrm{g} / \mathrm{L}$ in October to 71 $\mu \mathrm{g} / \mathrm{L}$ in June. The high concentration in June may be anomalous because it is substantially greater than any other measured value at this site, and substantially greater than the June value at the next downstream mainstem site on Tenmile Creek (site 28). Although concentration of lead might be expected to decrease in the downstream direction if intervening tributary flows are sufficient to provide a dilution, streamflow in June

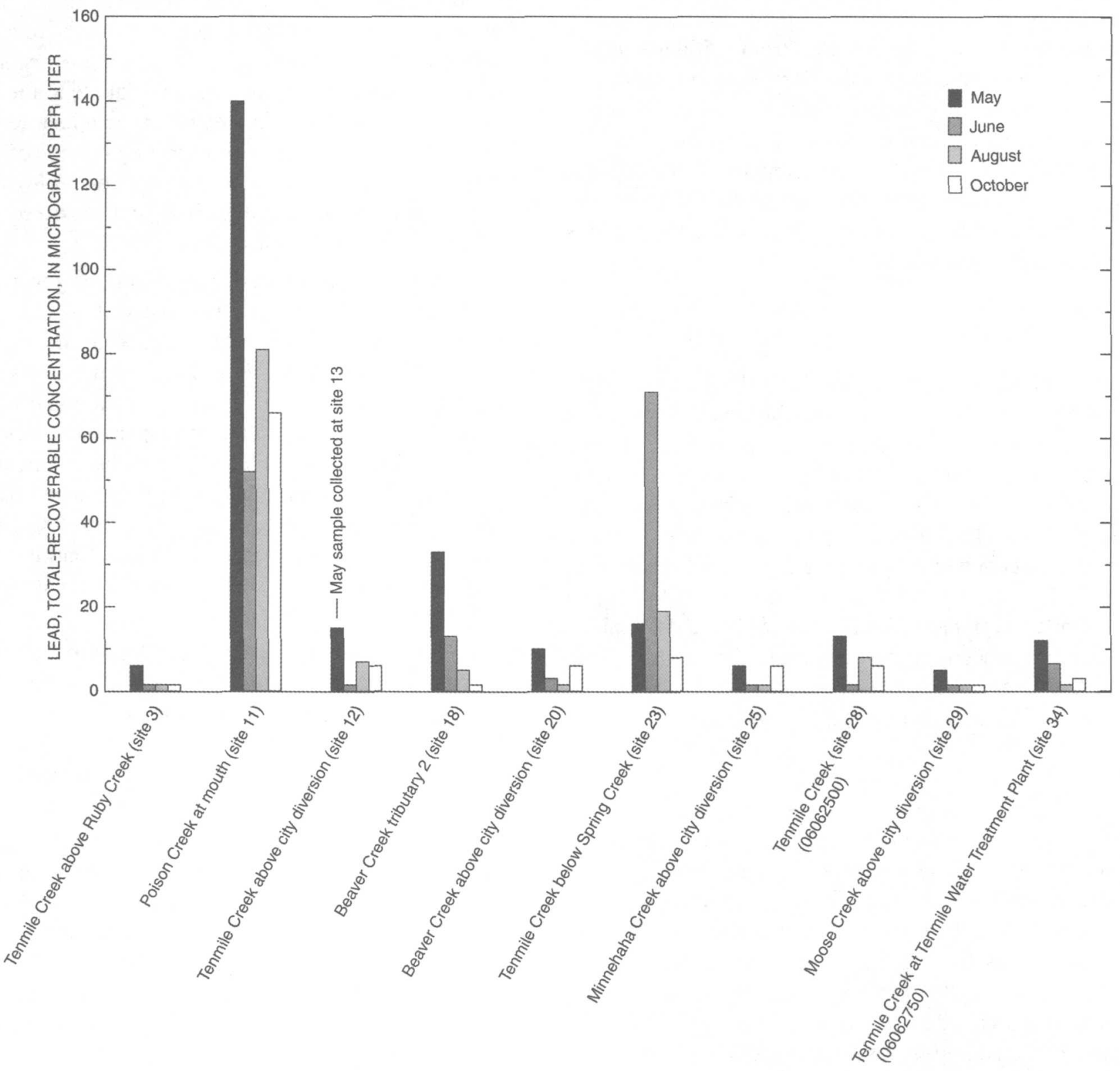

Figure 21. Total-recoverable lead concentrations in 1997 for selected sites in the upper Tenmile Creek watershed near Rimini, Montana. 
was similar at sites 23 and 28. Downstream, totalrecoverable lead concentrations in October were 6 $\mu \mathrm{g} / \mathrm{L}$ at Tenmile Creek near Rimini (site 28) and 3 $\mu \mathrm{g} / \mathrm{L}$ in Tenmile Creek at the Tenmile Water Treatment Plant (site 34). Total-recoverable lead concentrations in May at these sites were $13 \mu \mathrm{g} / \mathrm{L}$ and $12 \mu \mathrm{g} / \mathrm{L}$, respectively. Lead concentrations generally were close to or at the detection limit for most other sampling sites.

\section{Manganese}

Manganese concentrations generally were high at sampling sites associated with mine wastes. The highest concentrations, ranging from 1,500 to 1,800 $\mu \mathrm{g} / \mathrm{L}$, were found in samples from Poison Creek (site 11). Tenmile Creek below Spring Creek (site 23) had a large manganese concentration of $1,100 \mu \mathrm{g} / \mathrm{L}$ in August. Beaver Creek above tributary 3 (site 15) also had a large concentration of manganese $(370 \mu \mathrm{g} / \mathrm{L})$ in the August sample. All other sites had concentrations of $280 \mu \mathrm{g} / \mathrm{L}$ or less during the study.

\section{Chromium, Mercury, Nickel, Selenium, and Silver}

Minnehaha Creek above city diversion (site 25) was the only site having a detectable level of chromium $(1.0 \mu \mathrm{g} / \mathrm{L})$. Only one sample, perhaps an anomaly, had a mercury concentration $(5.8 \mu \mathrm{g} / \mathrm{L})$ above the detection limit. No samples had detectable levels of nickel. One sample from Poison Creek (site 11) had a detectable selenium concentration of $3 \mu \mathrm{g} / \mathrm{L}$ and one sample each from Tenmile Creek below Spring Creek (site 23) and Tenmile Creek near Rimini (site 28) had a detectable selenium concentration of $1.0 \mu \mathrm{g} / \mathrm{L}$. One sample from Walker Creek above city diversion (site 32 ) had a detectable concentration of silver of $10 \mu \mathrm{g} / \mathrm{L}$.

\section{Zinc}

As previously described, site to site comparisons of zinc concentrations cannot be made because of zinc contamination of the sample preservative. Nevertheless, results in table 13 indicate that all samples from Poison Creek (site 11) had total-recoverable zinc concentrations greatly in excess of the revised minimum reporting level of $100 \mu \mathrm{g} / \mathrm{L}$ with a high of $3,700 \mu \mathrm{g} / \mathrm{L}$ (site 18). In addition, total-recoverable zinc concentrations in all samples from Tenmile Creek above and below city diversion (sites 12 and 13), Beaver Creek tributary 2 (site 18), Spring Creek (site 22), Tenmile
Creek below Spring Creek (site 23), Minnehaha Creek above city diversion (site 25), Tenmile Creek near Rimini (site 28), and Tenmile Creek at the Tenmile Water Treatment Plant (site 34) were greater than 100 $\mu \mathrm{g} / \mathrm{L}$.

\section{Suspended Sediment}

Erosion of streambanks or unvegetated and disturbed areas, such as roads and mined areas, potentially can be a major source of suspended sediment in streams of the upper Tenmile Creek watershed. In addition, erosion of natural soils that consist of glacial tills and erosive granitic material and high-flow scour of streambed sediment deposits contribute to the suspended-sediment load in streams in the upper Tenmile Creek watershed. Factors influencing erosion of material into streams include cohesiveness of geologic parent materials, steepness of terrain, and proximity of sediments to streams (Hettinger, 1996).

Suspended-sediment concentrations generally were greatest in May during the early phases of spring runoff. Concentrations in May ranged from $6 \mathrm{mg} / \mathrm{L}$ in the sample from Beaver Creek above city diversion (site 20) to $150 \mathrm{mg} / \mathrm{L}$ in the sample from Poison Creek (site 11). The concentration of suspended sediment in Tenmile Creek was similar at all five mainstem sites $(3,13,23,28,34)$ in the May sampling (range of 20-34 $\mathrm{mg} / \mathrm{L})$. The small differences in suspended-sediment concentrations in May between sites on Tenmile Creek indicates that sediment contributions from tributaries are minor.

Runoff samples collected in June from sites on Tenmile Creek were low and showed little variability in suspended-sediment concentration, with values ranging from $6 \mathrm{mg} / \mathrm{L}$ to $9 \mathrm{mg} / \mathrm{L}$. The highest suspendedsediment concentration in any June sample was 18 $\mathrm{mg} / \mathrm{L}$ from Bear Gulch at mouth (site 31).

Suspended-sedimént concentrations during lowflow conditions generally were low. Suspended-sediment concentrations in samples from Tenmile Creek ranged from $2 \mathrm{mg} / \mathrm{L}$ to $12 \mathrm{mg} / \mathrm{L}$. The largest concentration $(56 \mathrm{mg} / \mathrm{L})$ was measured in the October sample from Moose Creek (site 29). This value may be anomalous because it is significantly larger than from any other sample from Moose Creek. The next largest suspended-sediment concentration during low-flow conditions was $21 \mathrm{mg} / \mathrm{L}$ from the October sample from Walker Creek (site 32). 


\section{Bottom Sediment}

Results of analyses of concentrations of trace elements in bottom sediment collected from Chessman Reservoir are shown in table 14.

The bottom-sediment sample from the wetland above Chessman Reservoir (site R3) had the highest concentrations of arsenic, cadmium, chromium, lead and zinc. This wetland receives runoff from the headwaters of Beaver Creek. Wetland soils are known for their ability to remove trace elements from surface water by adsorption, and constructed wetlands have been used extensively in the cleanup of mine-adit discharge (Klusman and Machemer, 1991).

The highest copper concentrations in bottomsediment samples were from the undredged portion of the reservoir at Chessman Reservoir Northeast (sites R2A and R2B). The surficial sediment sample taken from 0-7 in. (site R2A) had a copper concentration of $264 \mu \mathrm{g} / \mathrm{L}$, whereas the deeper sample taken from 7-9 in. (site R2B) had a copper concentration of $617 \mu \mathrm{g} / \mathrm{L}$. The larger concentration at greater sediment depth may reflect either a downward migration and accumulation of copper as a result of geochemical mobility, or it may represent a historical profile of greater copper applications in earlier years.

Sources for trace elements detected in the wetland and for trace elements other than copper in the reservoir are most likely eroded sediments from areas of naturally high mineralization. The transport of mine wastes may contribute some trace elements, particularly at Chessman Reservoir Southwest (site R1). This site is near the Banner Creek flume outfall. The Banner Creek flume passes through mine-waste rock piles at the Red Mountain Mine and downstream from the National Extension Mine. However, concentrations of trace elements at site $\mathrm{R} 1$ are not significantly larger than those at the other reservoir sites.

A comparison of trace-element concentrations in bottom sediment in Chessman Reservoir with concentrations in bottom sediment in Lake Helena (Kendy and others, 1998) is provided in table 14. Lake Helena is located just downstream from the mouth of Tenmile Creek, northeast of Helena. With the exception of chromium, trace-element concentrations in Chessman Reservoir and adjacent wetland bottom sediment generally equal or exceed the concentrations detected in Lake Helena sediments. Kendy and others (1998) also found that concentrations of arsenic, chromium, copper, lead, and zinc in bottom sediments in Lake Helena were comparable to concentrations in bottom sediments in seven mining-impaired wetlands and significantly greater than concentrations in 73 unimpaired wetlands throughout Montana. Kendy and others (1998) also report arsenic, copper, lead, and zinc concentrations in Lake Helena bottom sediment greatly exceed mean values and are near the upper end of ranges reported for more than 700 soil samples from the western United States. These comparisons indicate that trace elements from mining areas and areas of naturally high mineralization may accumulate in reservoir and wetland bottom sediments.

\section{Exceedances of Water-Quality Standards}

As previously described, concentrations of many inorganic constituents in several streams in the upper Tenmile Creek watershed were higher than those found in the relatively pristine headwaters streams or in Moose Creek. The relative degree of the amount of contamination in a stream can be assessed by comparing measured constituent concentrations with waterquality standards established for human health and aquatic life.

Water-quality standards for inorganic constituents (table 10) have been developed by the U.S. Environmental Protection Agency (EPA) and adopted by the State of Montana for the purpose of protecting life (Montana Department of Environmental Quality, 1995). These standards generally are different for human health and aquatic life. The water-quality standards discussed hereafter are those pertaining to trace elements, the constituents associated with past mining activities and of most concern in the upper Tenmile Creek watershed.

Published water-quality standards for trace elements are for the total-recoverable phase rather than the dissolved phase, unless otherwise noted. However, all water-quality samples that had total-recoverable or dissolved concentrations greater than the standards are noted in this report. This comparison of dissolved constituents to the standards is provided for general reference because of some uncertainty in the scientific community as to the predominant form of metal that may cause biological impairment. 


\section{Human Health}

Montana has adopted water-quality standards for chemical constituents that pose a risk to human health. In addition, two constituents, iron and manganese, have standards for aesthetic purposes such as taste, odor, and staining (Montana Department of Environmental Quality, 1995). Concentrations of three trace elements in the water-quality samples collected in the watershed exceeded human-health standards established for arsenic, cadmium, and lead. Although iron and manganese concentrations also exceeded human-health standards, these trace elements are not discussed because they pose no risk to health.

The current human-health standard in Montana for arsenic is $18 \mu \mathrm{g} / \mathrm{L}$. This standard was exceeded during runoff in May at Poison Creek (site 11), and Beaver Creek tributary 2 (site 18) in May and June. During low flows in August and October, the arsenic standard was exceeded at Tenmile Creek below Spring Creek (site 23), Tenmile Creek near Rimini (site 28), and Tenmile Creek at Tenmile Water Treatment Plant (site 34). Arsenic concentration also slightly exceeded the standard in August at Beaver Creek above tributary 3 (site 15). Arsenic concentrations were less than the human-health standard at all sites just above the city diversions to the water treatment plant (Banner Creek, Tenmile Creek, Beaver Creek, Minnehaha Creek, Moose Creek, and Walker Creek; sites 7, 12, 20, 25, 29, and 32). Arsenic is classified as a known human carcinogen, and chronic exposure is associated with symptoms such as pain, nausea, vomiting, and diarrhea (U.S. Department of Health and Human Services, 1993a).

The current human-health standard in Montana for cadmium is $5 \mu \mathrm{g} / \mathrm{L}$. The standard was exceeded in all samples collected from Poison Creek (site 11), Beaver Creek tributary 2 (site 18) in June, and Tenmile below Spring Creek (site 23) in August. The humanhealth standard for cadmium was not exceeded at any of the five sites just above the city diversions. Cadmium is a probable human carcinogen and cumulative toxin. The primary exposure for humans is cadmium dust on hands and cadmium uptake in garden vegetables. Ingestion of high cadmium levels irritates the stomach (U.S. Department of Health and Human Services, 1993b).

The current human-health standard in Montana for lead is $15 \mu \mathrm{g} / \mathrm{L}$. This standard was exceeded in all samples from Poison Creek (site 11), the May sample from Beaver Creek tributary 2 (site 18), and samples from Tenmile Creek below Spring Creek (site 23) in May, June, and August. The lead concentration in the May sample from Tenmile Creek collected below the city diversion (site 13) equaled the standard. The lead concentration at this site is presumed to be the same as the site above city diversion. Lead concentrations were less than the human-health standard for all samples from the five other sites just above the city diversions (sites 7, 20, 25, 29, and 32). High concentrations of lead have been shown to affect virtually every human organ. The most sensitive organs are the brain and kidneys. Low-level lead exposure may cause increased blood pressure, anemia and loss of memory in adults, and can impact the physical and mental development of children. The EPA considers lead compounds to be a possible human carcinogen (U.S. Department of Health and Human Services, 1993c). In the early part of this century, lead mining in the upper Tenmile Creek watershed was prohibited to protect the Helena water supply.

\section{Aquatic Life}

Different standards were developed for protection of aquatic-life from acute and chronic toxicity resulting from exposure to trace elements. Although most trace elements have both an acute and chronic standard, iron has only a chronic standard, and silver has only an acute standard. The acute standard indicates the maximum concentration that aquatic life generally can withstand for short periods (U.S. Environmental Protection Agency, 1986). The chronic standard is a lower concentration that, when exceeded over a long period, may result in suppression or impairment of normal biological functions (U.S. Environmental Protection Agency, 1986). Impairments can result in reduced growth rates or breeding activity. Fish, particularly trout, are the species considered most vulnerable to high concentrations of trace elements in the streams in the upper Tenmile Creek watershed.

The aquatic-life standards for cadmium, copper, lead, nickel, silver, and zinc are hardness-dependent. Equations for calculating the aquatic-life standard using measured hardness $\left(\mathrm{CaCO}_{3}\right.$ concentration) at the time of sampling are presented in table 15 . The equations in table 15 were used to calculate acute and chronic aquatic-life standards for cadmium, copper, lead, nickel, and silver for each water-quality sample. The measured concentrations of cadmium, copper, lead, nickel, and silver in individual samples then were 
compared to the calculated standards to identify which samples had exceeded the standards.

Sample concentrations that exceeded the humanhealth standard are shaded in table 13 at the back of the report. Concentrations that exceeded the acute and chronic aquatic-life standards are highlighted in italicized bold and bold type, respectively, in table 13 .

Results in table 13 indicate that acute and chronic aquatic-life standards for cadmium, copper, lead, and zinc in both the dissolved and total-recoverable phases were exceeded for many samples. Many samples also exceeded acute and chronic standards for dissolved aluminum, although only concentrations of total-recoverable aluminum were analyzed. The chronic standard for iron was exceeded for several samples from several streams. The acute standard for silver was exceeded one time at Walker Creek above city diversion (site 32), and the acute and chronic standards for mercury were exceeded one time at Banner Creek above city diversion (site 7).

\section{Constituent Transport in Streams}

The downstream transport of a constituent is commonly expressed as a mass of constituent (load) transported past a measuring location in a given period of time. Calculation of constituent load transport is a useful way to compare the relative contribution of constituent mass from streams having widely varying concentrations and flows. This allows identification of important sources introducing large quantities of a constituent that can substantially affect downstream water quality. For example, a tributary having a very high concentration of a constituent, but a very small discharge, will have little effect on a receiving stream that has a sufficiently large discharge to dilute the incoming constituent concentration. Conversely, a tributary having a very high concentration of a constituent may significantly increase the constituent concentration in the receiving stream if the discharge in the tributary is relatively large.

Instantaneous loads were calculated for selected total-recoverable trace-elements and suspended sediment for sampling sites in the upper Tenmile Creek watershed. Loads were compared among sites to indicate where the greatest inputs occurred during the prevailing hydrologic conditions at the time of sampling. Trace-element loads were calculated using concentrations analyzed in environmental samples and discharge measured at the time of sampling using the following equation:

$$
\mathrm{L}_{\mathrm{T}}=0.0054(\mathrm{Q})(\mathrm{C})
$$

where

$\mathrm{L}_{\mathrm{T}} \quad$ is the trace element load, in pounds, per day;

0.0054 is a units conversion factor;

$\mathrm{Q} \quad$ is stream discharge, in cubic feet per second; and

C is the trace-element concentration, in micrograms per liter.

Suspended-sediment loads were calculated using the following equation:

$$
\mathrm{L}_{\mathrm{S}}=5.4(\mathrm{Q})(\mathrm{C})
$$

where

$\mathrm{L}_{\mathrm{S}} \quad$ is the suspended-sediment load, in pounds, per day;

5.4 is a units conversion factor;

Q is the stream discharge, in cubic feet per second; and

$\mathrm{C}$ is the suspended-sediment concentration, in milligrams per liter.

Table 16 presents calculated instantaneous loads for selected trace elements and suspended sediment on individual sampling dates. Figures 22 through 25 depict the seasonal variations of chemical loads observed during May through October 1997 for arsenic, cadmium, copper, and lead. Values in table 16 with less-than symbols represent calculated loads based on the analytical detection limits for concentration of those constituents. For plotting purposes, calculated loads with less-than symbols were divided by two to indicate that loads were less than those shown in table 16. As indicated in table 16 and figures 22 through 25 , the impacts on downstream water quality from high concentrations of trace elements in small streams like Poison Creek are significant, but not as great as the constituent concentrations might indicate.

Table 16 and figure 22 indicate that arsenic loads in Tenmile Creek generally increased in the downstream direction during runoff in May and June and generally remained about the same or increased slightly during low-flow periods in August and October. The large increased arsenic loads in May at successive downstream locations evidently were from 


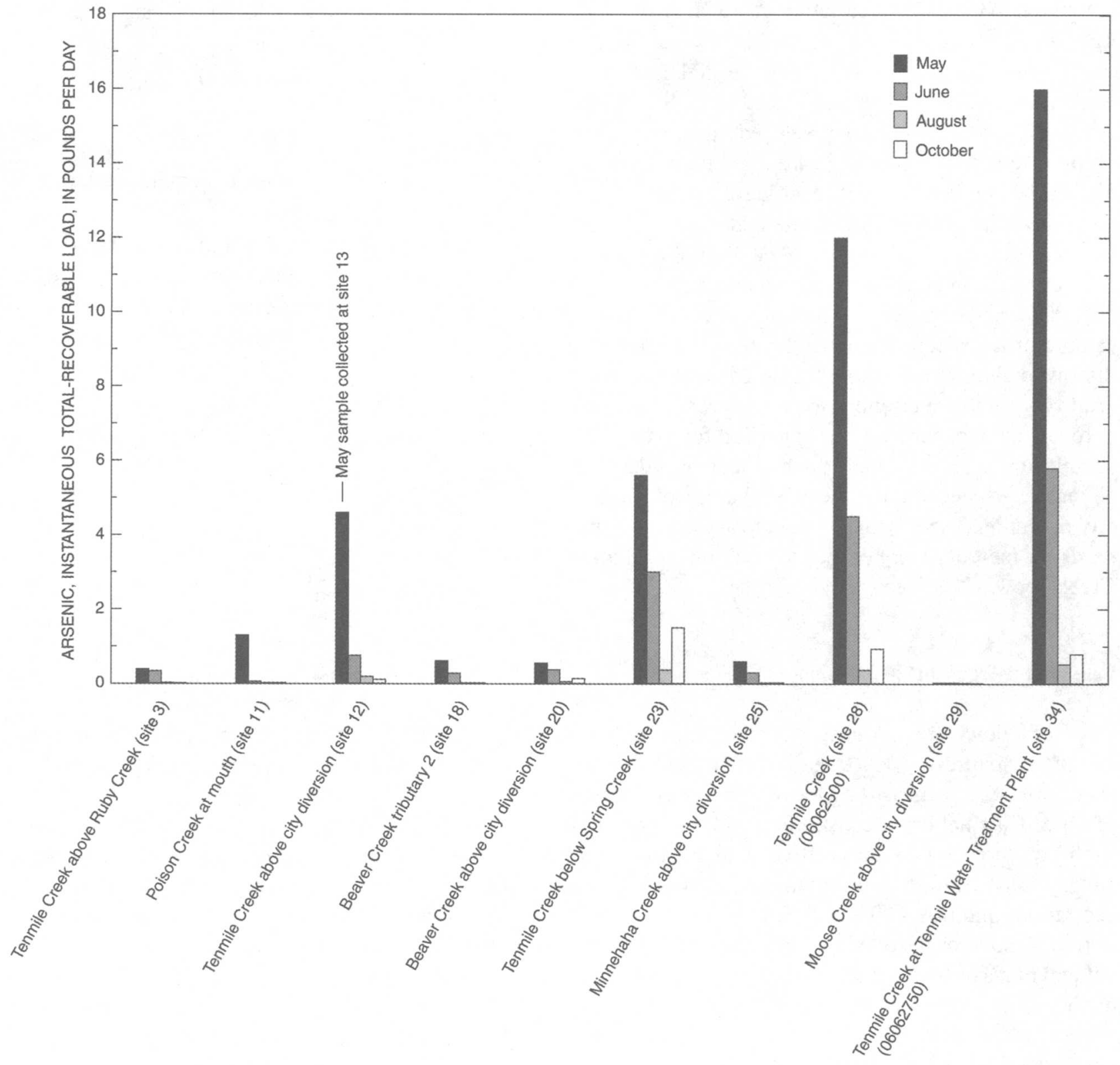

Figure 22. Instantaneous total-recoverable arsenic loads in 1997 for selected sites in the upperTenmile Creek watershed near Rimini, Montana.

unsampled tributaries such as Moore's Spring Creek, runoff from diffuse sources, or from resuspension of fine materials in the mainstem itself, because sampled tributary inputs, except from Poison Creek (site 11), were relatively small. Arsenic loads from the early runoff in May were substantially greater then loads from the later runoff in June and many times greater than loads from the low-flow periods in August and October. Arsenic load in Tenmile Creek decreased in
October from below Spring Creek (site 23) to the gage site near Rimini (site 28), but the decrease was relatively small and probably not significant.

As shown in figure 23, cadmium loads in Tenmile Creek also generally increased in the downstream direction during runoff in May and June and remained about the same from above the city diversion (site 12) to the Tenmile Water Treatment Plant (site 34) during the low-flow periods in August and October. Tributary 


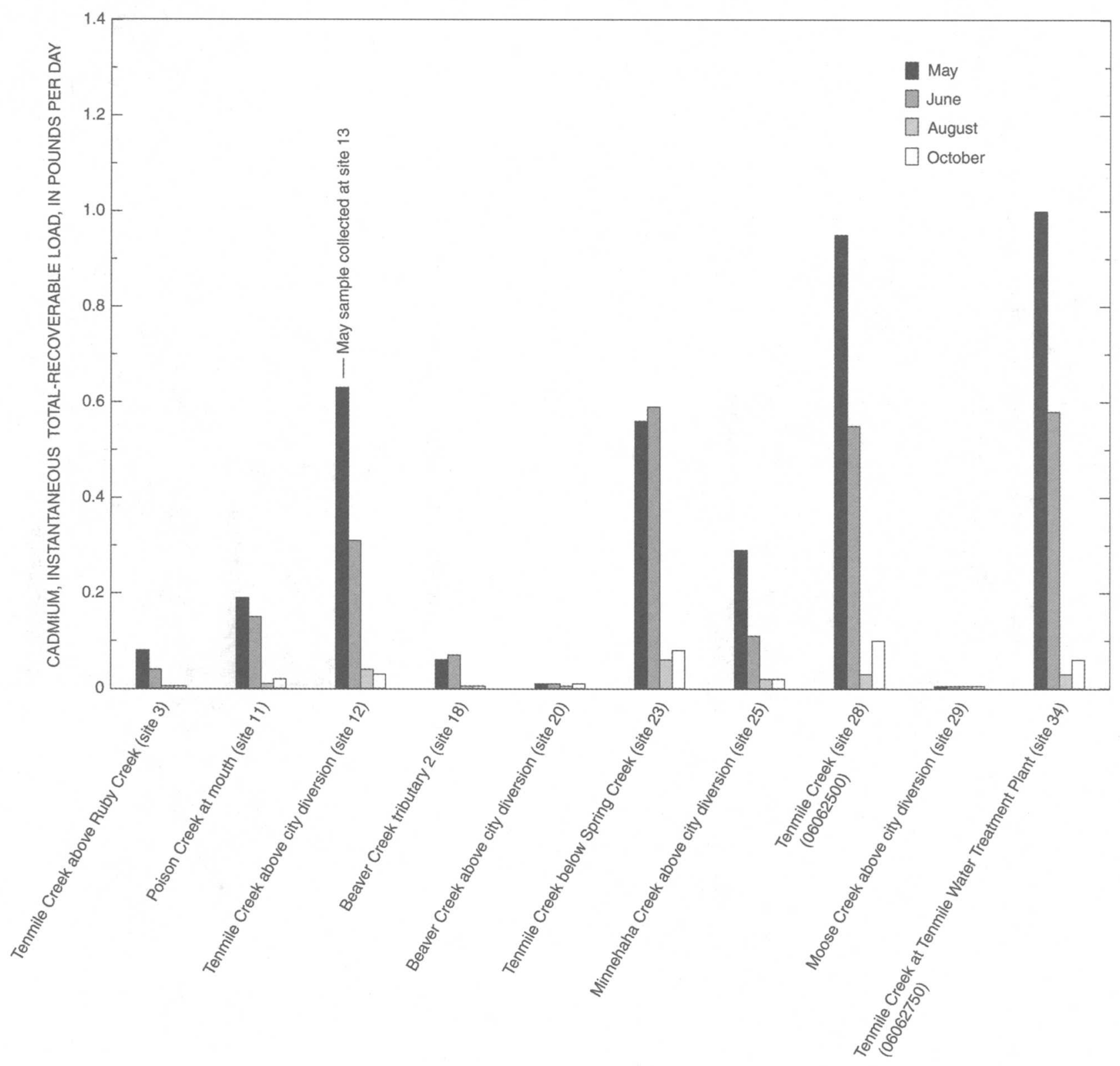

Figure 23. Instantaneous total-recoverable cadmium loads in 1997 for selected sites in the upper Tenmile Creek watershed near Rimini, Montana.

inputs of cadmium from Poison Creek (site 11) and Minnehaha Creek (site 25) were significant in May and June. As was the case with arsenic, cadmium loads in Tenmile Creek were significantly greater during the early runoff in May than during the later runoff in June, and loads during the low-flow periods in August and October were much less than during the runoff period. Cadmium load in Tenmile Creek decreased slightly in May from above the city diversion (site 12) to below
Spring Creek (site 23). Cadmium load in Tenmile Creek also decreased slightly in October from below Spring Creek to the gage site near Rimini (site 28) and from the gage site near Rimini to the Tenmile Water Treatment Plant (site 34). All decreases were relatively small and probably not significant.

Figure 24 shows that copper loads in Tenmile Creek also generally increased in the downstream direction during runoff conditions in May. Copper load 


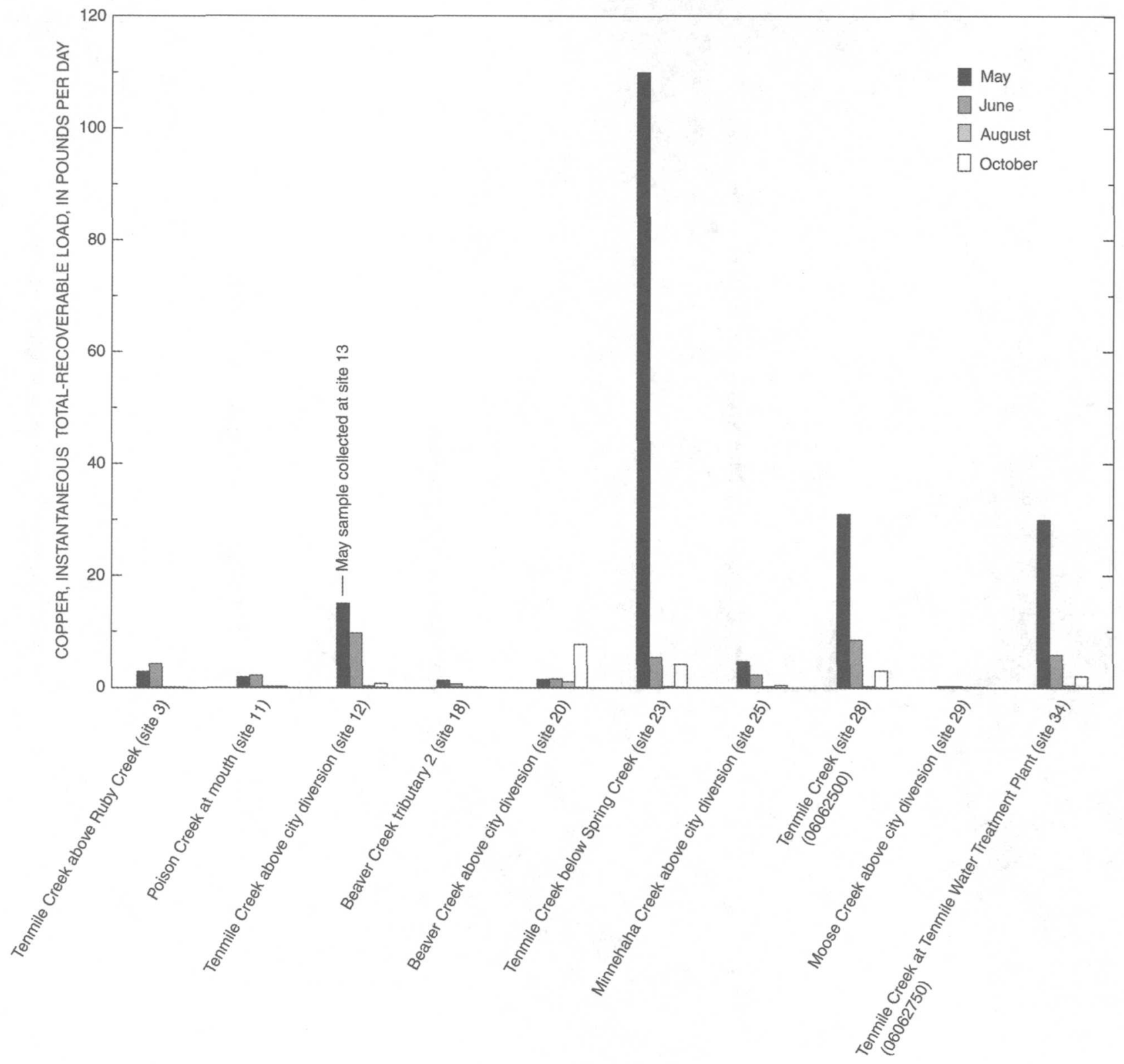

Figure 24. Instantaneous total-recoverable copper loads in 1997 for selected sites in the upperTenmile Creek watershed near Rimini, Montana.

in May was particularly high at Tenmile Creek below Spring Creek (site 23). The high May value at this site may be somewhat anomalous, however, given that it was twice as large as any other calculated value for May. Significant copper load was input to Tenmile Creek in May from all tributaries except Moose Creek (site 29). Copper loads in Tenmile Creek were substantially smaller in June than in May at most sites. Copper loads were relatively small at all sites in August and at sites upstream from Beaver Creek (site 20) in October. Beaver Creek had a relatively large copper load in October, presumably the result of copper-laden flow releases from Chessman Reservoir, and copper loads were elevated at all mainstem sites downstream from Beaver Creek (sites 23, 28, and 34).

As shown in figure 25, all sites had their largest lead loads in May, except for Tenmile Creek below Spring Creek (site 23), which had a large load in June. 


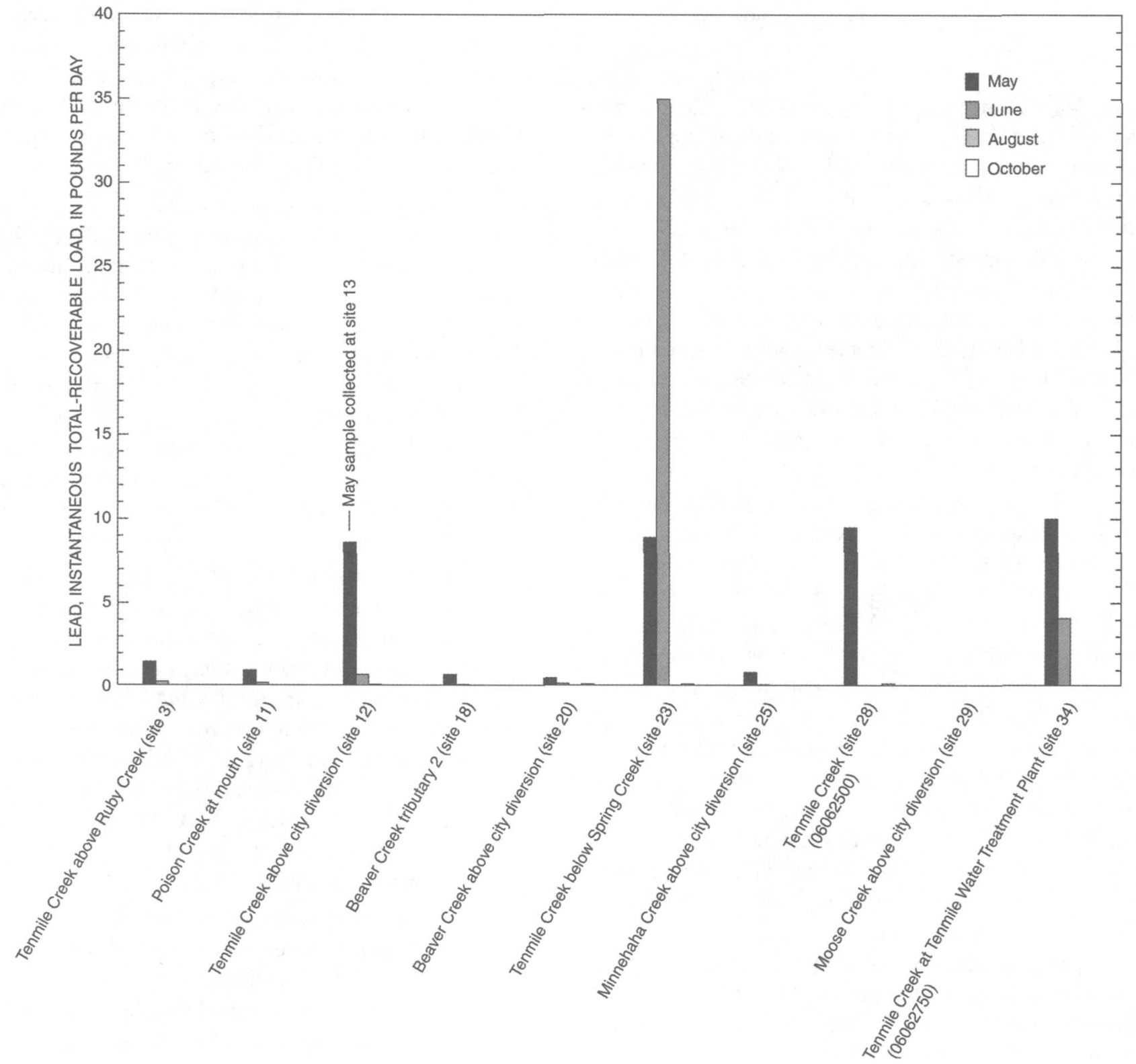

Figure 25. Instantaneous total-recoverable lead loads in 1997 for selected sites in the upper Tenmile Creek watershed near Rimini, Montana.

Except for the notably large and perhaps anomalous June value, lead loads did not increase appreciably downstream from Tenmile Creek above city diversion (site 12). Thus, lead inputs from tributaries were relatively minor for all months.

\section{SUMMARY}

Tenmile Creek is a small mountain stream in Lewis and Clark County, Montana. Upper Tenmile Creek provides most of the drinking water for the City of Helena and also has been the focus of numerous small hard-rock mining operations since 1864 .

Because of the municipal water demands, portions of the stream are dewatered every year. In addition, contaminated drainage from inactive mines periodically enters the stream. Because of these impacts on water quantity and quality, the Upper Tenmile Watershed Steering Group was formed and initiated a cooperative hydrologic investigation of the Upper Tenmile Creek watershed by the Montana Department of Natural 
Resources and Conservation, Lewis and Clark County, and the USGS.

In May 1997, the USGS installed 32 streamstage gages throughout the upper Tenmile Creek watershed. In addition, one continuous-record streamflowgaging station was established, and one discontinued, long-term continuous-record streamflow-gaging station (Tenmile Creek near Rimini, station 06062500) was re-established. Nineteen of these 34 data-collection sites subsequently were used for the estimation of long-term monthly natural streamflow, and 21 were used for the collection of water-quality information. Nineteen sites were intended for possible use to estimate daily natural discharge for Tenmile Creek near Rimini, but most ultimately were used only for verification purposes.

To estimate long-term monthly natural flows at locations throughout the upper basin, a multi-step correlation procedure was used.

Step 1: Historical metered and observed wateruse data for the Tenmile Water Treatment Plant for water years 1991-98 and October 1998 (first month of water year 1999) and measured discharge data from May through October 1997 for the current study were used to estimate long-term monthly natural flows for 1961-90 for Tenmile Creek near Rimini.

Step 2: Metered and observed water-use data for the Tenmile Water Treatment Plant and measured discharge for the current study were used to estimate daily natural flows during May through October 1997 for Tenmile Creek near Rimini.

Step 3: Measured and observed discharges during May through September 1997 at 19 monthly flow-estimation sites were regressed with concurrent estimated daily natural discharges for Tenmile Creek near Rimini. The regression relation then was used to estimate long-term monthly natural flows at each of the 19 sites from the long-term monthly natural flows for Tenmile Creek near Rimini.

To test the reliability of the regression equations, a test using a nearby, long-term streamflow-gaging station was used. The station, Prickly Pear Creek near Clancy, was considered to be an estimation site, and the logarithms of 20 randomly selected daily mean discharges from May through October 1997 were regressed against logarithms of concurrent daily natural discharges for Tenmile Creek near Rimini. The resultant regression equation was used to calculate long-term mean monthly discharge for Prickly Pear Creek, and the calculated values were compared to actual, recorded values of mean monthly discharge. Estimation errors ranged from -6.6 percent in February to 14.2 percent in August. Based on the test results, estimation errors for most sites in the upper Tenmile Creek watershed are believed to be about the same or slightly larger than those for the test.

Two series of gain-loss discharge measurements were conducted in September 1998 and July 1999 to help determine whether Tenmile Creek gains flow from or loses flow to ground water between the city diversion in Rimini and the Tenmile Water Treatment Plant. Both series of measurements indicated that gains in flow occur between the city diversion and the mouth of Walker Creek and that losses in flow occur from the mouth of Walker Creek to the treatment plant. These results indicate that streamflow gains in the upper part of the watershed generally offset losses in the lower part.

Stream water from 21 sites in the upper Tenmile Creek watershed was sampled and analyzed for various chemical constituents over a wide range of flows.

Sampling sites included locations near the mouths of major Tenmile Creek tributaries and key locations on Beaver Creek and Tenmile Creek. Most sites were sampled in May, June, August, and October, although some sites were sampled fewer than four times because of access problems or lack of flow. Samples were analyzed for concentrations of major ions, nutrients, trace elements, and suspended sediment.

Because of the application of copper sulfate to water in Chessman Reservoir to retard algae growth, five samples of bottom sediment in the reservoir and an adjacent wetland were collected September 8, 1997 from four selected locations. The bottom sediment samples were analyzed for concentrations of arsenic, cadmium, chromium, copper, lead, and zinc.

Water and sediment samples were collected in accordance with USGS standard methods. Water samples were analyzed by Montana Tunnels, Inc. Suspended-sediment samples were analyzed by the USGS sediment laboratory in Helena, Montana, and reservoir bed-sediment samples were analyzed by the NWQL.

Quality-assurance data included field-blank samples of deionized water and replicate environmental samples incorporated into routine sample sets submitted to the laboratory. Quality-control samples comprised about 10 percent of the total number of water samples and consisted of two deionized water blanks and two replicates per sampling trip. 
Zinc contamination of field blanks was large and persistent. Based on a test of five blank samples in October 1997, it was determined that vials of nitric acid preservative from the routine supplier used during the study had consistently measurable concentrations of zinc. Thus, zinc concentrations in any environmental sample less than the maximum concentration found in any field blank $(100 \mu \mathrm{g} / \mathrm{L})$ may be unreliable.

Surface water in the upper Tenmile Creek watershed generally is a calcium bicarbonate type. Hardness ranged from $9 \mathrm{mg} / \mathrm{L}$ to $82 \mathrm{mg} / \mathrm{L}$. Sulfate concentrations tended to be largest in areas associated with mining activity. The largest sulfate concentration in any sample was $99 \mathrm{mg} / \mathrm{L}$ for the August sample from Tenmile Creek below Spring Creek, at Rimini. Nutrient concentrations were very low in all samples collected.

Trace-element concentrations varied widely throughout the upperTenmile Creek watershed. Very low concentrations generally were found in the headwater streams Monitor Creek, Ruby Creek, Banner Creek, and Tenmile Creek above city diversion and in the tributary streams Moose Creek, Bear Gulch, and Walker Creek. Consistently high concentrations of trace elements were found in samples from Poison Creek, Beaver Creek tributary 2, and Tenmile Creek below Spring Creek--all sites downstream from mines or mine waste rock. Samples from Poison Creek had the highest concentrations of aluminum $(2,400 \mu \mathrm{g} / \mathrm{L})$, arsenic $(180 \mu \mathrm{g} / \mathrm{L})$, cadmium $(30 \mu \mathrm{g} / \mathrm{L})$, lead $(140 \mu \mathrm{g} / \mathrm{L})$, manganese $(1,800 \mu \mathrm{g} / \mathrm{L})$, and zinc $(3,700$ $\mu \mathrm{g} / \mathrm{L})$ found in the study. The highest concentration of copper attributable to mining activity also was found in Poison Creek $(420 \mu \mathrm{g} / \mathrm{L})$. The highest concentration of copper, which is probably attributable to copper sulfate addition to Chessman Reservoir, was found in Beaver Creek above tributary $3(430 \mu \mathrm{g} / \mathrm{L})$. The highest concentration of cadmium $(30 \mu \mathrm{g} / \mathrm{L})$ was found in samples from Poison Creek and Tenmile Creek below Spring Creek and the highest concentration of iron $(3,800$ $\mu \mathrm{g} / \mathrm{L}$ ) was found in samples from Tenmile Creek below Spring Creek.

Suspended-sediment concentrations generally were greatest in May during spring runoff. Concentrations in May ranged from $6 \mathrm{mg} / \mathrm{L}$ in Beaver Creek above city diversion to $150 \mathrm{mg} / \mathrm{L}$ in Poison Creek. Concentrations of suspended sediment in May did not vary significantly in Tenmile Creek $(20 \mathrm{mg} / \mathrm{L}$ to 34 $\mathrm{mg} / \mathrm{L}$ ). Suspended-sediment concentrations generally were low during low-flow conditions, ranging from 2 $\mathrm{mg} / \mathrm{L}$ to $21 \mathrm{mg} / \mathrm{L}$.
Copper concentrations in bottom sediment from Chessman Reservoir were greater than concentrations found in bed sediment from Lake Helena. Concentrations of other trace elements in bed sediment from Chessman Reservoir were about the same as those found in bed sediment from Lake Helena, except for chromium. The concentration of chromium was less in bed sediment from Chessman Reservoir than in bed sediment from Lake Helena.

Water-quality standards for chemical constituents that pose a risk to human health were exceeded for arsenic, cadmium, and lead. The human-health standard for arsenic, $18 \mu \mathrm{g} / \mathrm{L}$, was exceeded in May at Poison Creek, in May and June at Beaver Creek tributary 2, and in August and October at Tenmile Creek below Spring Creek, Tenmile Creek near Rimini, and Tenmile Creek at Tenmile Water Treatment Plant. Arsenic concentrations were less than the human-health standard at all sites just above the city diversions. The humanhealth standard for cadmium, $5 \mu \mathrm{g} / \mathrm{L}$, was exceeded in all samples from Poison Creek, Beaver Creek tributary 2 in June, and Tenmile Creek below Spring Creek in August. Cadmium concentrations were less than the human-health standard at all sites just above the city diversions. Concentrations of lead were greater than the human-health standard $(15 \mu \mathrm{g} / \mathrm{L})$ in all samples from Poison Creek, the May sample from Beaver Creek tributary 2, and samples from Tenmile Creek below Spring Creek in May, June, and August. The May sample from Tenmile Creek below the city diversion, which is presumed equivalent to a sample from above the city diversion, had a lead concentration equal to the human-health standard. No samples from five other sites just above city diversions had lead concentrations that exceeded human-health standards.

Acute and chronic aquatic-life standards for cadmium, copper, and lead were exceeded for many samples throughout the watershed. The chronic standard for iron was exceeded for several samples from several streams.

Constituent loads were calculated for selected trace elements and suspended sediment. Loads varied seasonally, with the largest values occurring during high-flow conditions in May and June. Due to lower streamflow, loads in Poison Creek, the most highly contaminated stream in the watershed in terms of traceelement concentrations, generally were not as large as loads in several other tributaries and in the Tenmile Creek mainstem. 


\section{SELECTED REFERENCES}

Edwards, T.K., and Glysson, G.D., 1988, Field methods for measurement of fluvial sediment: U.S. Geological Survey Techniques of Water-Resources Investigations, book 3, chap. $\mathrm{C} 2,80 \mathrm{p}$.

Guy, H.P., and Norman, V.W., 1970, Field methods for measurement of fluvial sediment: U.S. Geological Survey Techniques of Water-Resources Investigations, book 3, chapter $\mathrm{C} 2,59 \mathrm{p}$.

Hettinger, P.S., 1996, Integrating social assessment and biophysical characterization for watershed protection of upper Tenmile Creek near Helena, Montana: Missoula, Mont., University of Montana, M.S. thesis, $170 \mathrm{p}$.

Horowitz, A.J., Demas, C.R., Fitzgerald, K.K., Miller, T.L., and Rickert, D.A., 1994, U.S. Geological Survey protocol for the collection and processing of surfacewater samples for the subsequent determination of inorganic constituents in filtered water: U.S. Geological Survey Open-File Report 94-539, 57 p.

Kendy, Eloise, Olsen, Bill, and Malloy, J.C., 1998, Field screening of water quality, bottom sediment, and biota associated with irrigation drainage in the Helena Valley, west-central Montana, 1995: U.S. Geological Survey Water-Resources Investigations Report 97-4214, 62 p.

Klusman, R.W., and Machemer, S.D., 1991, Natural processes of acidity reduction and metal removal from acid mine drainage, in Peters, D.C., ed., Geology in coal resource utilization: Fairfax, Va., Tech Books, p. 513540 .

Knapton, J.R., 1985, Field guidelines for collection, treatment, and analysis of water samples, Montana District: U.S. Geological Survey Open-File Report 85409, 86 p.

Knapton, J.R., and Nimick, D.A., 1991, Quality assurance for water-quality activities of the U.S. Geological Survey in Montana: U.S. Geological Survey Open-File Report 91-216, $41 \mathrm{p}$.

Lambing, J.H., 1991, Water-quality and transport characteristics of suspended sediment and trace elements in streamflow of the upper Clark Fork basin from Galen to Missoula, Montana, 1985-90: U.S. Geological Survey Water-Resources Investigations Report 91-4139, 73 p.

Lambing, J.H., and Dodge, K.A., 1993, Quality assurance for laboratory analysis of suspended-sediment samples by the U.S. Geological Survey in Montana: U.S. Geological Survey Open-File Report 93-131, 34 p.
Lambing, J.H., Jones, W.E., Sutphin, J.W., 1988, Reconnaissance investigation of water quality, bottom sediment, and biota associated with irrigation drainage in the Bowdoin National Wildlife Refuge and adjacent areas of the Milk River basin, northeastern Montana, 1986-87: U.S. Geological Survey Water-Resources Investigations Report 87-4243, 71 p.

Montana Department of Environmental Quality, 1995, Montana numeric water quality standards: Helena, Mont., Water Quality Division, Circular WQB-7, 39 p.

Montana Department of Environmental Quality, 1996, Abandoned hardrock mine priority sites, 1996, supplemental summary report: Prepared by Pioneer Technical Services, Inc., Butte, Mont., for the Abandoned Mine Reclamation Bureau [variously paged].

Montana Department of Environmental Quality, 1998, Abandoned and inactive mine scoring system (AIMSS) list: Helena, Mont., Mine Waste Cleanup Bureau, Remediation Division [variously paged].

Montana Department of State Lands, 1995, Abandoned hardrock mine priority sites, 1995, summary report: Prepared by Pioneer Technical Services, Inc., Butte, Mont., for the Abandoned Mine Reclamation Bureau [variously paged].

Montana Tunnels Mining, Inc., 1997, Quality assurance manual: Jefferson City, Mont., Water Quality Laboratory, revised May 10, 1997 .[variously paged].

Moreland, J.A., 1995, Quality-assurance plan for waterresources activities of the U.S. Geological Survey in Montana--1995, Revised: U.S. Geological Survey Open-File Report 91-194, Revised, 23 p.

Parrett, Charles, Johnson, D.R., and Hull, J.A., 1989, Estimates of monthly streamflow characteristics at selected sites in the upper Missouri River basin, Montana, base period water years 1937-86: U. S. Geological Survey Water-Resources Investigations Report 89-4082, 103 p.

Parrett, Charles, and Cartier, Kenn D., 1990, Methods for estimating monthly streamflow characteristics at ungaged sites in western Montana: U. S. Geological Survey Water-Supply Paper 2365, $30 \mathrm{p}$.

Rantz, S.E., and others, 1982, Measurement and computation of streamflow--Volume 1, Measurement of stage and discharge: U.S. Geological Survey WaterSupply Paper 2175, 273 p.

Severson, R.C., Wilson, S.A., and McNeal, J.M., 1987, Analyses of bottom material collected at nine areas in the western United States for the DOI irrigation drainage task group: U.S. Geological Survey Open-File Report 87-490, $24 \mathrm{p}$. 
U.S. Department of Agriculture, 1989, Soil survey of the Helena National Forest Area, Montana: Helena, Mont., U.S. Forest Service, in cooperation with the Soil Conservation Service and Montana Agricultural Experiment Station, $266 \mathrm{p}$.

U.S. Department of Health and Human Services, 1993a, Toxicological profile for arsenic: Life Systems, Inc., for Clement International Corporation for the Agency for Toxic Substances and Disease Registry, TP-92/02, unpaged.

U.S. Department of Health and Human Services, 1993b, Toxicological profile for cadmium: Life Systems, Inc., for Clement International Corporation for the Agency for Toxic Substances and Disease Registry, TP-92/06, unpaged.

U.S. Department of Health and Human Services, 1993c, Toxicological profile for lead: Clement International Corporation, for the Agency for Toxic Substances and Disease Registry, TP-92/12, unpaged.
U.S. Environmental Protection Agency, 1983, Methods for chemical analysis of water and wastes: Cincinnati, Ohio, Environmental Monitoring and Support Laboratory, EPA-600/4-79-020, unpaged.

U.S. Environmental Protection Agency, 1986, Quality criteria for water 1986: Washington, D.C., Office of Water Regulations and Standards, EPA 440/5-86-001, unpaged.

U.S. Environmental Protection Agency, 1991, Methods for the determination of organic compounds in drinking water: Washington, D.C., EPA Office of Research and Development, EPA/600/4-88/-39, method 515.1, p. 222. (July 1991 revision of Dec. 1988 report.)

U.S. Geological Survey, 1977, National handbook of recommended methods for water-data acquisition-Chapter 5, Chemical and physical quality of water and sediment: U.S. Geological Survey Office of Water Data Coordination, $193 \mathrm{p}$.

Ward, J.R., and Harr, C.A., eds., 1990, Methods for collection and processing of surface-water and bedmaterial samples for physical and chemical analyses: U.S. Geological Survey Open-File Report 90-140, 71 p. 
Table 1. Streamflow data-collection sites and purposes, upper Tenmile Creek watershed, Montana [Symbols: $x$, signifies site used for indicated purpose; --, signifies site not used for indicated purpose]

\begin{tabular}{|c|c|c|c|c|}
\hline \multirow[b]{2}{*}{$\begin{array}{c}\text { Site } \\
\text { number }\end{array}$} & \multirow[b]{2}{*}{$\begin{array}{c}\text { Station name } \\
\text { (USGS streamflow-gaging station number in parentheses) }\end{array}$} & \multicolumn{3}{|c|}{ Intended station use } \\
\hline & & $\begin{array}{l}\text { Estimation of long- } \\
\text { term monthly } \\
\text { natural discharge }\end{array}$ & $\begin{array}{c}\text { Water-quality } \\
\text { sampling and } \\
\text { analysis }\end{array}$ & $\begin{array}{c}\text { Estimation of } 1997 \\
\text { daily natural flow } \\
\text { for Tenmile Creek } \\
\text { near Rimini }\end{array}$ \\
\hline 1 & Monitor Creek at mouth, near Rimini & $\mathbf{X}$ & $\mathrm{X}$ & -- \\
\hline 2 & Tenmile Creek below Monitor Creek, near Rimini & $\mathrm{X}$ & $\mathrm{X}$ & -- \\
\hline 3 & Tenmile Creek above Ruby Creek, near Rimini & $\mathrm{X}$ & $\mathrm{X}$ & -- \\
\hline 4 & Ruby Creek above Scott Reservoir, near Rimini ${ }^{2}$ & -- & -- & $\mathrm{X}$ \\
\hline 5 & Ruby Creek below Scott Reservoir, near Rimini ${ }^{2}$ & -- & -- & $\mathrm{X}$ \\
\hline 6 & Ruby Creek at mouth, near Rimini & $X$ & $\mathrm{X}$ & -- \\
\hline 7 & Banner Creek above city diversion, near Rimini & $\mathrm{X}$ & $\mathrm{X}$ & $\mathrm{X}$ \\
\hline 8 & Banner Creek flume below city diversion, near Rimini ${ }^{2}$ & -- & -- & $\mathrm{X}$ \\
\hline 9 & Banner Creek tributary near Rimini ${ }^{1}$ & $\mathrm{X}$ & $\mathrm{X}$ & -- \\
\hline 10 & Banner Creek below city diversion, near Rimini & -- & $\mathrm{X}$ & $X$ \\
\hline 11 & Poison Creek at mouth, near Rimini & $\mathrm{X}$ & $\mathrm{X}$ & -- \\
\hline 12 & Tenmile Creek above city diversion, near Rimini & $\mathrm{X}$ & $\mathrm{X}$ & $\mathrm{X}$ \\
\hline 13 & Tenmile Creek below city diversion, near Rimini & -- & $\mathrm{X}$ & $\mathrm{X}$ \\
\hline 14 & Beaver Creek above Chessman Reservoir, near Rimini ${ }^{2}$ & -- & -- & $\mathrm{X}$ \\
\hline 15 & Beaver Creek above tributary 3, near Rimini & -- & $\mathrm{X}$ & $\mathrm{X}$ \\
\hline 16 & Beaver Creek tributary 3 near Rimini & $\mathrm{X}$ & -- & -- \\
\hline 17 & Beaver Creek below tributary 3, near Rimini ${ }^{2}$ & -- & -- & $\mathrm{X}$ \\
\hline 18 & Beaver Creek tributary 2 near Rimini & $\mathrm{X}$ & $\mathrm{X}$ & -- \\
\hline 19 & Beaver Creek tributary 1 near Rimini & $\mathrm{X}$ & -- & -- \\
\hline 20 & Beaver Creek above city diversion, near Rimini & $\mathrm{X}$ & $\mathrm{X}$ & $\mathrm{X}$ \\
\hline 21 & Beaver Creek below city diversion, at Rimini ${ }^{2}$ & -- & -- & $\mathrm{X}$ \\
\hline 22 & Spring Creek at mouth, at Rimini & $\mathrm{X}$ & $\mathrm{X}$ & -- \\
\hline 23 & Tenmile Creek below Spring Creek, at Rimini & -- & $\mathrm{X}$ & - \\
\hline 24 & Moore's Spring Creek at mouth, at Rimini & $\mathrm{X}$ & - & -- \\
\hline 25 & Minnehaha Creek above city diversion, near Rimini & $\mathrm{X}$ & $X$ & $X$ \\
\hline 26 & Minnehaha Creek below city diversion, near Rimini ${ }^{2}$ & -- & -- & $\mathrm{X}$ \\
\hline 27 & Deer Creek at mouth, near Rimini ${ }^{1}$ & $\mathrm{X}$ & -- & -- \\
\hline 28 & Tenmile Creek near Rimini (06062500) & $\mathrm{X}$ & $\mathrm{X}$ & $\mathrm{X}$ \\
\hline 29 & Moose Creek above city diversion, near Rimini & $\mathrm{X}$ & $\mathrm{X}$ & $\mathrm{X}$ \\
\hline 30 & Moose Creek below city diversion, near Rimini ${ }^{2}$ & -- & -- & $\mathrm{X}$ \\
\hline 31 & Bear Gulch at mouth, near Rimini & $\mathrm{X}$ & $\mathrm{X}$ & -- \\
\hline 32 & Walker Creek above city diversion, near Rimini & $\mathrm{X}$ & $\mathrm{X}$ & $\mathrm{X}$ \\
\hline 33 & Walker Creek below city diversion, near Rimini ${ }^{2}$ & -- & -- & $\mathrm{X}$ \\
\hline 34 & Tenmile Creek at Tenmile Water Treatment Plant, near Rimini (06062750) & $\mathbf{X}$ & $\mathrm{X}$ & -- \\
\hline
\end{tabular}

\footnotetext{
${ }^{1}$ Dropped from analysis due to very small flows.

${ }^{2}$ Ultimately not used for natural flow estimation; municipal water-use data were used instead.
} 
Table 2. Discharge measurement sites, drainage area sizes, measurement dates, measured stage, and discharge, upper Tenmile Creek watershed, Montana

[Abbreviations: $\mathrm{ft}$, feet; mi, mile. Symbol: --, no data]

\begin{tabular}{|c|c|c|c|c|c|c|}
\hline $\begin{array}{l}\text { Site } \\
\text { No. }\end{array}$ & $\begin{array}{l}\text { Site name } \\
\text { (USGS streamflow-gaging } \\
\text { station number } \\
\text { in parentheses) }\end{array}$ & Site description & $\begin{array}{l}\text { Drainage } \\
\text { area, } \\
\text { square } \\
\text { miles }\end{array}$ & Date & $\begin{array}{c}\text { Stage, } \\
\text { feet }\end{array}$ & $\begin{array}{c}\text { Dis- } \\
\text { charge, } \\
\text { cubic feet } \\
\text { per } \\
\text { second }\end{array}$ \\
\hline 1 & Monitor Creek at mouth, near Rimini & $\begin{array}{l}\text { Lat } 46^{\circ} 27^{\prime} 21^{\prime \prime} \text {, long } 112^{\circ} 16^{\prime} 48^{\prime \prime} \text {, in SW } 1 / 4 \mathrm{NE} 1 / 4 \mathrm{SW} 1 / 4 \mathrm{sec} .7 \text {, T. } 8 \\
\text { N., R. } 5 \text { W., about } 20 \mathrm{ft} \text { upstream from mouth and about } 4.0 \mathrm{mi} \text { south- } \\
\text { west of Rimini }\end{array}$ & 1.7 & $\begin{array}{l}07 / 17 / 97 \\
07 / 30 / 97 \\
08 / 25 / 97 \\
10 / 06 / 97\end{array}$ & $\begin{array}{r}0.68 \\
.58 \\
.55 \\
.48\end{array}$ & $\begin{array}{r}1.38 \\
.66 \\
.53 \\
.18\end{array}$ \\
\hline 2 & $\begin{array}{l}\text { Tenmile Creek below Monitor Creek, } \\
\text { near Rimini }\end{array}$ & $\begin{array}{l}\text { Lat } 46^{\circ} 27^{\prime} 22^{\prime \prime} \text {, long } 112^{\circ} 16^{\prime} 46^{\prime \prime} \text {, in SE } 1 / 4 \mathrm{NE} 1 / 4 \mathrm{SW} 1 / 4 \mathrm{sec} .7, \mathrm{~T} .8 \\
\text { N., R. } 5 \text { W., about } 100 \mathrm{ft} \text { below the confluence of Monitor Creek and } \\
\text { Tenmile Creek and about } 3 \mathrm{mi} \text { southwest of Rimini }\end{array}$ & 4.18 & $\begin{array}{l}05 / 13 / 97 \\
05 / 14 / 97 \\
06 / 03 / 97 \\
07 / 17 / 97 \\
07 / 30 / 97\end{array}$ & $\begin{array}{r}1.00 \\
1.10 \\
1.09 \\
.56 \\
.45\end{array}$ & $\begin{array}{c}20.9 \\
30.6 \\
31.4 \\
2.52 \\
1.36\end{array}$ \\
\hline 3 & $\begin{array}{l}\text { Tenmile Creek above Ruby Creek, } \\
\text { near Rimini }\end{array}$ & $\begin{array}{l}\text { Lat } 46^{\circ} 27^{\prime} 21^{\prime \prime} \text {, long } 112^{\circ} 15^{\prime} 40^{\prime \prime} \text {, in SE } 1 / 4 \mathrm{NW} 1 / 4 \mathrm{SW} 1 / 4 \mathrm{sec} .8, \mathrm{~T} .8 \\
\text { N., R. } 5 \mathrm{~W} \text {., at timber bridge crossing about } 0.1 \mathrm{mi} \text { upstream from } \\
\text { Ruby Creek and about } 2.5 \mathrm{mi} \text { southwest of Rimini }\end{array}$ & 6.28 & $\begin{array}{l}05 / 13 / 97 \\
05 / 14 / 97 \\
06 / 03 / 97 \\
07 / 17 / 97 \\
07 / 30 / 97 \\
08 / 25 / 97 \\
10 / 06 / 97\end{array}$ & $\begin{array}{r}1.06 \\
1.24 \\
1.03 \\
.50 \\
.40 \\
.37 \\
.30\end{array}$ & $\begin{array}{l}37 \\
47.8 \\
41.0 \\
4.83 \\
2.11 \\
1.67 \\
.91\end{array}$ \\
\hline 4 & $\begin{array}{l}\text { Ruby Creek above Scott Reservoir, } \\
\text { near Rimini }\end{array}$ & $\begin{array}{l}\text { Lat } 46^{\circ} 25^{\prime} 54^{\prime \prime} \text {, long } 112^{\circ} 15^{\prime} 59^{\prime \prime} \text {, in NE1/4SE } 1 / 4 \text { NE } 1 / 4 \text { sec. } 19 \text {, T. } 8 \\
\text { N., R. } 5 \text { W., at Parshall flume about } 100 \mathrm{ft} \text { upstream from Scott Reser- } \\
\text { voir and about } 5.3 \text { mi southwest of Rimini }\end{array}$ & .85 & $\begin{array}{l}07 / 30 / 97 \\
07 / 01 / 98\end{array}$ & $\begin{array}{l}.07 \\
.35\end{array}$ & $\begin{array}{r}.27 \\
3.02\end{array}$ \\
\hline 5 & $\begin{array}{l}\text { Ruby Creek below Scott Reservoir, } \\
\text { near Rimini }\end{array}$ & $\begin{array}{l}\text { Lat } 46^{\circ} 25^{\prime}, 57^{\prime \prime} \text {, long } 112^{\circ} 15^{\prime} 40^{\prime \prime} \text {, in NE } 1 / 4 \mathrm{SW} 1 / 4 \mathrm{NW} 1 / 4 \mathrm{sec} .20 \text {, T. } 8 \\
\text { N., R. } 5 \text { W., at Parshall flume below reservoir face and about } 5.2 \mathrm{mi} \\
\text { southwest of Rimini }\end{array}$ & 1.03 & $\begin{array}{l}07 / 30 / 97 \\
07 / 01 / 98\end{array}$ & $\begin{array}{l}.15 \\
.04\end{array}$ & $0^{.24}$ \\
\hline 6 & Ruby Creek at mouth, near Rimini & $\begin{array}{l}\text { Lat } 46^{\circ} 27^{\prime} 19^{\prime \prime} \text {, long } 112^{\circ} 15^{\prime} 34^{\prime \prime} \text {, in SW } 1 / 4 \mathrm{NE} 1 / 4 \mathrm{SW} 1 / 4 \mathrm{sec} .8, \mathrm{~T} .8 \\
\text { N., R. } 5 \text { W., about } 300 \mathrm{ft} \text { upstream from mouth and about } 2.5 \mathrm{mi} \text { south- } \\
\text { west of Rimini }\end{array}$ & 2.09 & $\begin{array}{l}05 / 13 / 97 \\
05 / 14 / 97 \\
06 / 03 / 97 \\
07 / 17 / 97 \\
07 / 30 / 97 \\
08 / 25 / 97 \\
10 / 06 / 97\end{array}$ & $\begin{array}{l}1.74 \\
1.83 \\
1.91 \\
1.39 \\
1.29 \\
1.29 \\
1.39\end{array}$ & $\begin{array}{c}8.89 \\
10.9 \\
17.4 \\
.88 \\
.33 \\
.40 \\
1.80\end{array}$ \\
\hline 8 & $\begin{array}{l}\text { Banner Creek flume below city } \\
\text { diversion, near Rimini }\end{array}$ & $\begin{array}{l}\text { Lat } 46^{\circ} 27^{\prime} 28^{\prime \prime} \text {, long } 112^{\circ} 14^{\prime} 32^{\prime \prime} \text {, in NE } 1 / 4 \mathrm{NW} 1 / 4 \mathrm{SW} 1 / 4 \mathrm{sec} .9, \mathrm{~T} .8 \\
\text { N., R. } 5 \text { W., at Parshall flume about } 100 \mathrm{ft} \text { downstream from city } \\
\text { diversion structure and about } 2.2 \mathrm{mi} \text { south of Rimini }\end{array}$ & 3.76 & 05/29/97 & 1.08 & 6.85 \\
\hline 9 & Banner Creek tributary near Rimini & $\begin{array}{l}\text { Lat } 46^{\circ} 27^{\prime} 40^{\prime \prime} \text {, long } 112^{\circ} 14^{\prime} 35^{\prime \prime} \text {, in NW } 1 / 4 \mathrm{SW} 1 / 4 \mathrm{NW} 1 / 4 \mathrm{sec} .9, \mathrm{~T} .8 \\
\text { N., R. } 5 \text { W., at culvert crossing on Rimini Road about } 2.0 \mathrm{mi} \text { south of } \\
\text { Rimini }\end{array}$ & .4 & $\begin{array}{l}07 / 30 / 97 \\
08 / 25 / 97\end{array}$ & $\begin{array}{l}.29 \\
.32\end{array}$ & $\begin{array}{l}.28 \\
.26\end{array}$ \\
\hline 10 & $\begin{array}{l}\text { Banner Creek below city diversion, } \\
\text { near Rimini }\end{array}$ & $\begin{array}{l}\text { Lat } 46^{\circ} 27^{\prime} 45^{\prime \prime} \text {, long } 112^{\circ} 14^{\prime} 50^{\prime \prime} \text {, in NW } 1 / 4 \mathrm{NW} 1 / 4 \mathrm{NE} 1 / 4 \mathrm{sec} .8 \text {, T. } 8 \\
\text { N., R. } 5 \text { W., at bridge crossing on Rimini Road about } 2.3 \mathrm{mi} \text { south of } \\
\text { Rimini }\end{array}$ & 4.29 & $\begin{array}{l}05 / 13 / 97 \\
05 / 14 / 97 \\
07 / 17 / 97\end{array}$ & $\begin{array}{l}2.16 \\
2.39 \\
1.65\end{array}$ & $\begin{array}{r}19.6 \\
28.7 \\
3.24\end{array}$ \\
\hline 11 & Poison Creek at mouth, near Rimini & $\begin{array}{l}\text { Lat } 46^{\circ} 28^{\prime} 38^{\prime \prime}, \text { long } 112^{\circ} 14^{\prime} 39^{\prime \prime} \text {, in SW } 1 / 4 \mathrm{NW} 1 / 4 \mathrm{NW} 1 / 4 \mathrm{sec} .4 \text {, T. } 8 \\
\text { N., R. } 5 \text { W., at culvert crossing on Rimini Road about } 1.0 \mathrm{mi} \text { south of } \\
\text { Rimini }\end{array}$ & .32 & $\begin{array}{l}05 / 13 / 97 \\
05 / 16 / 97 \\
06 / 03 / 97 \\
07 / 17 / 97 \\
07 / 30 / 97 \\
08 / 25 / 97 \\
10 / 07 / 97\end{array}$ & $\begin{array}{l}1.01 \\
2.03 \\
1.86 \\
1.78 \\
1.73 \\
1.75 \\
1.75\end{array}$ & $\begin{array}{r}1.36 \\
1.38 \\
.92 \\
.18 \\
.10 \\
.08 \\
1.10\end{array}$ \\
\hline
\end{tabular}


Table 2. Discharge measurement sites, drainage area sizes, measurement dates, measured stage, and discharge, upper Tenmile Creek watershed, Montana (Continued)

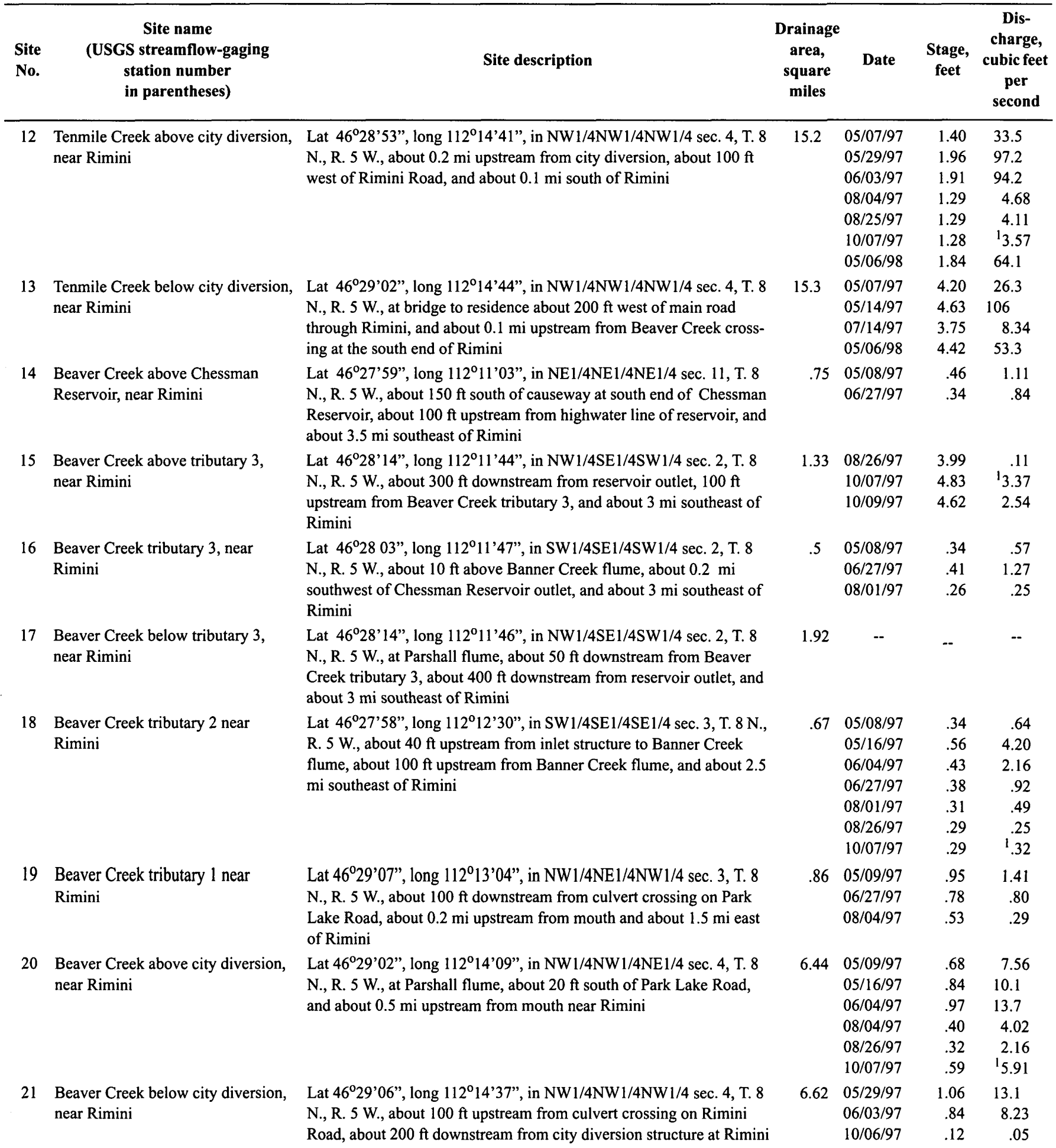


Table 2. Discharge measurement sites, drainage area sizes, measurement dates, measured stage, and discharge, upper Tenmile Creek watershed, Montana (Continued)

\begin{tabular}{|c|c|c|c|c|c|c|}
\hline $\begin{array}{l}\text { Site } \\
\text { No. }\end{array}$ & $\begin{array}{l}\text { Site name } \\
\text { (USGS streamflow-gaging } \\
\text { station number } \\
\text { in parentheses) }\end{array}$ & Site description & $\begin{array}{l}\text { Drainage } \\
\text { area, } \\
\text { square } \\
\text { miles }\end{array}$ & Date & $\begin{array}{l}\text { Stage, } \\
\text { feet }\end{array}$ & $\begin{array}{c}\text { Dis- } \\
\text { charge, } \\
\text { cubic feet } \\
\text { per } \\
\text { second }\end{array}$ \\
\hline 22 & Spring Creek at mouth, at Rimini & $\begin{array}{l}\text { Lat } 46^{\circ} 29^{\prime} 21^{\prime \prime} \text {, long } 112^{\circ} 14^{\prime} 57^{\prime \prime} \text {, in SW } 1 / 4 \mathrm{NW} 1 / 4 \mathrm{SW} 1 / 4 \mathrm{sec} .33 \text {, T. } 8 \\
\text { N., R. } 5 \text { W., about } 100 \mathrm{ft} \text { upstream from Banks residence, about } 0.2 \mathrm{mi} \\
\text { upstream from mouth, at Rimini }\end{array}$ & .64 & $\begin{array}{l}05 / 09 / 97 \\
05 / 15 / 97 \\
06 / 04 / 97 \\
08 / 26 / 97 \\
10 / 07 / 97\end{array}$ & $\begin{array}{l}.54 \\
.85 \\
.58 \\
.33 \\
.33\end{array}$ & $\begin{array}{r}1.45 \\
5.81 \\
2.38 \\
.29 \\
1.31\end{array}$ \\
\hline 23 & $\begin{array}{l}\text { Tenmile Creek below Spring Creek, } \\
\text { at Rimini }\end{array}$ & $\begin{array}{l}\text { Lat } 46^{\circ} 29^{\prime} 22^{\prime \prime} \text {, long } 112^{\circ} 14^{\prime} 54^{\prime \prime} \text {, in NW } 1 / 4 \mathrm{SW} 1 / 4 \mathrm{SW} 1 / 4 \mathrm{sec} .33 \text {, T. } 8 \\
\text { N., R. } 5 \text { W., at bridge crossing on road to Banks residence at Rimini }\end{array}$ & 22.8 & $\begin{array}{l}05 / 15 / 97 \\
06 / 04 / 97 \\
08 / 26 / 97 \\
10 / 06 / 97 \\
10 / 07 / 97 \\
10 / 09 / 97\end{array}$ & $\begin{array}{c}-- \\
-- \\
1.93 \\
1.95 \\
-- \\
2.31\end{array}$ & $\begin{array}{r}103 \\
91.7 \\
.39 \\
.36 \\
4.50 \\
3.48\end{array}$ \\
\hline 25 & $\begin{array}{l}\text { Minnehaha Creek above city diver- } \\
\text { sion, near Rimini }\end{array}$ & $\begin{array}{l}\text { Lat } 46^{\circ} 30^{\prime} 23^{\prime \prime} \text {, long } 112^{\circ} 15^{\prime} 37^{\prime \prime} \text {, in NW } 1 / 4 \mathrm{NW} 1 / 4 \mathrm{SE} 1 / 4 \mathrm{sec} .29 \text {, T. } 9 \\
\text { N., R. } 5 \text { W., about } 75 \mathrm{ft} \text { upstream from city diversion structure, about } \\
200 \mathrm{ft} \text { upstream from mouth, and about } 3.0 \text { mi north of Rimini }\end{array}$ & 5.35 & $\begin{array}{l}05 / 09 / 97 \\
05 / 15 / 97 \\
06 / 02 / 97 \\
06 / 27 / 97 \\
08 / 04 / 97 \\
08 / 27 / 97 \\
10 / 08 / 97\end{array}$ & $\begin{array}{l}1.84 \\
2.16 \\
1.97 \\
1.71 \\
1.51 \\
1.50 \\
1.50\end{array}$ & $\begin{array}{c}12.4 \\
27.3 \\
17.9 \\
7.5 \\
2.22 \\
1.74 \\
{ }^{1} 2.17\end{array}$ \\
\hline 26 & $\begin{array}{l}\text { Minnehaha Creek below city diver- } \\
\text { sion, near Rimini }\end{array}$ & $\begin{array}{l}\text { Lat } 46^{\circ} 30^{\prime} 23^{\prime \prime} \text {, long } 112^{\circ} 15^{\prime} 37^{\prime \prime} \text {, in NW1/4NW } 1 / 4 \mathrm{SE} 1 / 4 \mathrm{sec} .29 \text {, T. } 9 \\
\text { N., R. } 5 \mathrm{~W} \text {., about } 40 \mathrm{ft} \text { downstream from city diversion structure, } \\
\text { about } 90 \mathrm{ft} \text { upstream from mouth, and about } 3.0 \mathrm{mi} \text { north of Rimini }\end{array}$ & 5.35 & $\begin{array}{l}05 / 09 / 97 \\
06 / 27 / 97 \\
07 / 14 / 97 \\
08 / 04 / 97\end{array}$ & $\begin{array}{l}3.29 \\
2.91 \\
2.68 \\
2.52\end{array}$ & $\begin{array}{r}11.6 \\
.89 \\
.26 \\
.09\end{array}$ \\
\hline 29 & $\begin{array}{l}\text { Moose Creek above city diversion, } \\
\text { near Rimini }\end{array}$ & $\begin{array}{l}\text { Lat } 46^{\circ} 31 \text { ' } 29^{\prime \prime} \text {, long } 112^{\circ} 15^{\prime} 10^{\prime \prime} \text {, in NE1/4SE } 1 / 4 \mathrm{NE} 1 / 4 \mathrm{sec} .20 \text {, T. } 9 \\
\text { N., R. } 5 \text { W., about } 75 \mathrm{ft} \text { upstream from city diversion structure, about } \\
0.1 \text { mi east of Rimini Road, and about } 4.0 \text { mi north of Rimini }\end{array}$ & 2.86 & $\begin{array}{l}05 / 15 / 97 \\
06 / 02 / 97 \\
08 / 04 / 97 \\
08 / 27 / 97 \\
10 / 09 / 97\end{array}$ & $\begin{array}{r}1.36 \\
1.33 \\
1.16 \\
22.06 \\
22.14\end{array}$ & $\begin{array}{r}2.56 \\
2.45 \\
.84 \\
1.03 \\
.45\end{array}$ \\
\hline 30 & $\begin{array}{l}\text { Moose Creek below city diversion, } \\
\text { near Rimini }\end{array}$ & $\begin{array}{l}\text { Lat } 46^{\circ} 31 \text { ' } 29^{\prime \prime} \text {, long } 112^{\circ} 15^{\prime} 10^{\prime \prime} \text {, in NE } 1 / 4 \mathrm{SE} 1 / 4 \mathrm{NE} 1 / 4 \mathrm{sec} .20 \text {, T. } 9 \\
\text { N., R. } 5 \mathrm{~W} \text {., about } 10 \mathrm{ft} \text { downstream from city diversion structure, } \\
\text { about } 0.1 \text { mi east of Rimini Road, and about } 4.0 \text { mi north of Rimini }\end{array}$ & 2.86 & $\begin{array}{l}08 / 04 / 97 \\
08 / 27 / 97\end{array}$ & $\begin{array}{l}1.69 \\
2.03\end{array}$ & $\begin{array}{l}.005 \\
.13\end{array}$ \\
\hline
\end{tabular}


Table 2. Discharge measurement sites, drainage area sizes, measurement dates, measured stage, and discharge, upper Tenmile Creek watershed, Montana (Continued)

\begin{tabular}{|c|c|c|c|c|c|c|}
\hline $\begin{array}{l}\text { Site } \\
\text { No. }\end{array}$ & $\begin{array}{l}\text { Site name } \\
\text { (USGS streamflow-gaging } \\
\text { station number } \\
\text { in parentheses) }\end{array}$ & Site description & $\begin{array}{l}\text { Drainage } \\
\text { area, } \\
\text { square } \\
\text { miles }\end{array}$ & Date & $\begin{array}{l}\text { Stage, } \\
\text { feet }\end{array}$ & $\begin{array}{c}\text { Dis- } \\
\text { charge, } \\
\text { cubic feet } \\
\text { per } \\
\text { second }\end{array}$ \\
\hline 31 & Bear Gulch at mouth, near Rimini & $\begin{array}{l}\text { Lat } 46^{\circ} 32^{\prime} 39^{\prime \prime} \text {, long } 112^{\circ} 14^{\prime} 42^{\prime \prime} \text {, in NE } 1 / 4 \mathrm{NW} 1 / 4 \mathrm{NW} 1 / 4 \mathrm{sec} .16, \mathrm{~T} .9 \\
\text { N., R. } 5 \text { W., about } 50 \mathrm{ft} \text { upstream from culvert crossing on Rimini } \\
\text { Road, and about } 5.0 \text { mi north of Rimini }\end{array}$ & 1.06 & $\begin{array}{l}05 / 09 / 97 \\
05 / 16 / 97 \\
05 / 29 / 97 \\
06 / 02 / 97 \\
07 / 14 / 97 \\
08 / 27 / 97 \\
10 / 08 / 97\end{array}$ & $\begin{array}{l}.35 \\
.38 \\
.38 \\
.35 \\
.23 \\
.21 \\
.22\end{array}$ & $\begin{array}{r}1.55 \\
1.36 \\
1.52 \\
1.26 \\
.28 \\
.10 \\
1.18\end{array}$ \\
\hline 32 & $\begin{array}{l}\text { Walker Creek above city diversion, } \\
\text { near Rimini }\end{array}$ & $\begin{array}{l}\text { Lat } 46^{\circ} 33^{\prime} 44^{\prime \prime} \text {, long } 112^{\circ} 14^{\prime} 19^{\prime \prime} \text {, in NW1/4NW } 1 / 4 \mathrm{SE} 1 / 4 \mathrm{sec} .4 \text {, T. } 9 \\
\text { N., R. } 5 \text { W., about } 50 \mathrm{ft} \text { upstream from city diversion structure, about } \\
0.1 \text { mi upstream from mouth, and about } 6.0 \text { mi north of Rimini }\end{array}$ & 11.3 & $\begin{array}{l}05 / 12 / 97 \\
05 / 16 / 97 \\
06 / 02 / 97 \\
08 / 04 / 97 \\
08 / 27 / 97 \\
10 / 08 / 97\end{array}$ & $\begin{array}{r}1.66 \\
1.96 \\
1.64 \\
.54 \\
.54 \\
.70\end{array}$ & $\begin{array}{c}21.3 \\
28.6 \\
19.0 \\
1.71 \\
1.25 \\
{ }^{1} 2.68\end{array}$ \\
\hline 34 & $\begin{array}{l}\text { Tenmile Creek at Tenmile Water } \\
\text { Treatment Plant, near Rimini } \\
(06062750)\end{array}$ & $\begin{array}{l}\text { Lat } 46^{\circ} 34^{\prime} 19^{\prime \prime} \text {, long } 112^{\circ} 12^{\prime} 52^{\prime \prime} \text {, in SEl/4SW } 1 / 4 \mathrm{SE} 1 / 4 \mathrm{sec} .34 \text {, T. } 10 \\
\mathrm{~N} ., \mathrm{R} .5 \mathrm{~W} ., \text { on left bank at bridge to Helena Water Treatment Plant, } \\
\text { about } 0.2 \mathrm{mi} \text { south of U.S. Highway } 12 \text {, and about } 8 \mathrm{mi} \text { north of } \\
\text { Rimini }\end{array}$ & 51.1 & $\begin{array}{l}05 / 07 / 97 \\
05 / 15 / 97 \\
06 / 05 / 97 \\
06 / 11 / 97 \\
06 / 25 / 97 \\
07 / 08 / 97 \\
08 / 13 / 97 \\
08 / 27 / 97 \\
08 / 27 / 97 \\
10 / 07 / 97\end{array}$ & $\begin{array}{l}2.26 \\
2.80 \\
2.54 \\
2.86 \\
2.06 \\
1.76 \\
1.44 \\
1.52 \\
1.68 \\
--\end{array}$ & $\begin{array}{c}72.5 \\
177 \\
108 \\
199 \\
39.4 \\
17.7 \\
2.20 \\
4.69 \\
{ }^{1} 5.20 \\
38.10\end{array}$ \\
\hline
\end{tabular}

${ }^{1}$ Estimated from instantaneous stage reading applied to stage-discharge relationship.

${ }^{2}$ Stage-discharge relationship invalid because of backwater conditions.

${ }^{3}$ Daily mean discharge from continuously recorded stage. 
Table 3. Net monthly discharges into Scott and Chessman Reservoirs calculated from daily water-use data at Tenmile Water Treatment Plant, Montana

[Net monthly discharge into either reservoir is negative whenever outflow exceeds inflow]

\begin{tabular}{|c|c|c|c|c|c|c|c|c|c|c|c|c|}
\hline \multirow{2}{*}{$\begin{array}{l}\text { Water } \\
\text { year }\end{array}$} & \multicolumn{12}{|c|}{ Net monthly discharge into Scott Reservoir, in cubic feet per second } \\
\hline & Oct. & Nov. & Dec. & Jan. & Feb. & Mar. & Apr. & May & June & July & Aug. & Sept. \\
\hline 1991 & 0 & 0 & 0 & 0 & 0 & 0 & 0 & 0 & 0 & 0 & -1.49 & -1.78 \\
\hline 1993 & -.94 & -.76 & -.39 & 0 & -.78 & -.68 & 0 & 0 & 0 & 0 & 0 & 0 \\
\hline 1994 & -.02 & -.31 & -.31 & -1.03 & -1.40 & -.91 & -.32 & 0 & 0 & -1.77 & -6.93 & -.41 \\
\hline 1997 & -.68 & -.22 & -.81 & -.81 & -.81 & -.52 & 0 & 0 & 0 & -.04 & -.08 & -1.65 \\
\hline 1998 & -1.42 & -1.42 & -1.42 & -1.42 & -1.42 & -1.42 & -.02 & 0 & 0 & 0 & -1.25 & -4.00 \\
\hline 1999 & -.78 & & & & & & & & & & & \\
\hline
\end{tabular}

Average net monthly inflow -0.71

\begin{tabular}{|c|c|c|c|c|c|c|c|c|c|c|c|c|}
\hline \multirow{2}{*}{$\begin{array}{l}\text { Water } \\
\text { year }\end{array}$} & \multicolumn{12}{|c|}{ Net monthly discharge into Chessman Reservoir, in cubic feet per second } \\
\hline & Oct. & Nov. & Dec. & Jan. & Feb. & Mar. & Apr. & May & June & July & Aug. & Sept. \\
\hline 1991 & -2.32 & -2.40 & -3.30 & -2.86 & -2.21 & -1.82 & -0.03 & 0 & 0 & 0 & 0 & 0 \\
\hline 1992 & 0 & 0 & -1.24 & -1.95 & -1.15 & -.15 & .76 & 3.45 & 0 & 0 & -.31 & -2.15 \\
\hline 1993 & -.45 & -1.21 & -1.74 & -2.95 & -2.69 & -2.18 & 0 & 6.17 & 7.95 & 1.57 & 0 & 0 \\
\hline 1994 & 0 & 0 & 0 & 0 & 0 & 0 & 0 & -.36 & -.57 & -.05 & 0 & -4.76 \\
\hline 1995 & -.68 & -.66 & -1.31 & -1.90 & -1.45 & -.41 & 0 & 5.00 & -.67 & 0 & 0 & -.66 \\
\hline 1996 & -.80 & -.70 & -1.58 & -1.36 & -2.40 & -2.57 & -.52 & 2.57 & 5.50 & -2.25 & -5.32 & -4.13 \\
\hline 1997 & -3.50 & -3.01 & -2.38 & -2.18 & -1.78 & -.62 & 0 & 5.84 & 9.18 & 1.55 & 0 & -2.24 \\
\hline 1998 & -2.68 & -1.96 & -1.97 & -1.11 & -1.15 & -.80 & 0 & 3.25 & 2.59 & -1.89 & -1.66 & -1.85 \\
\hline 1999 & -1.40 & & & & & & & & & & & \\
\hline
\end{tabular}


Table 4. Monthly mean discharge diverted to Tenmile Water Treatment Plant, Montana

\begin{tabular}{|c|c|c|c|c|c|c|c|c|c|c|c|c|}
\hline $\begin{array}{l}\text { Water } \\
\text { year }\end{array}$ & \multicolumn{12}{|c|}{ Discharge, in cubic feet per second } \\
\hline 1991 & 5.6 & 4.3 & 4.9 & 5.2 & 4.8 & 4.8 & 4.9 & 6.5 & 7.5 & 9.4 & 6.5 & 6.3 \\
\hline 1993 & 5.5 & 4.9 & 4.7 & 5.4 & 5.6 & 6.0 & 5.3 & 8.3 & 8.3 & 6.7 & 7.6 & 5.9 \\
\hline 1994 & 5.0 & 5.0 & 4.7 & 4.7 & 4.7 & 4.7 & 5.3 & 8.1 & 11.3 & 12.7 & 12.6 & 9.4 \\
\hline 1996 & 5.2 & 4.7 & 4.6 & 4.5 & 5.3 & 4.9 & 4.8 & 5.7 & 10.2 & 12.7 & 12.4 & 9.0 \\
\hline 1997 & 6.0 & 4.9 & 4.7 & 5.2 & 4.9 & 4.4 & 5.1 & 8.0 & 8.9 & 11.2 & 9.2 & 8.5 \\
\hline 1998 & 5.6 & 4.9 & 4.8 & 4.9 & 5.1 & 5.1 & 5.8 & 10.1 & 7.3 & 11.1 & 12.1 & 10.1 \\
\hline 1999 & 5.8 & & & & & & & & & & & \\
\hline
\end{tabular}


Table 5. Natural flow accretions forTenmile Creek near Rimini, Montana

\begin{tabular}{|c|c|c|c|c|c|c|c|c|c|c|c|c|c|}
\hline \multirow{2}{*}{$\begin{array}{l}\text { Water } \\
\text { year }\end{array}$} & \multicolumn{13}{|c|}{ Discharge, in cubic feet per second } \\
\hline & Oct. & Nov. & Dec. & Jan. & Feb. & Mar. & Apr. & May & June & July & Aug. & Sept. & Annual \\
\hline 1991 & 2.2 & 1.1 & 0.8 & 1.4 & 1.8 & 2.2 & 4.1 & 12.5 & 13.3 & 7.8 & 3.9 & 3.4 & 4.6 \\
\hline 1992 & 2.4 & .9 & .2 & 2.0 & 2.8 & 3.9 & 4.1 & 19.1 & 13.2 & 4.3 & 3.0 & 2.1 & 4.9 \\
\hline 1993 & 3.2 & 2.1 & 1.8 & 1.6 & 1.2 & 2.2 & 4.4 & 20.1 & 21.8 & 7.2 & 6.3 & 4.9 & 6.4 \\
\hline 1994 & 4.2 & 3.8 & 3.6 & 2.9 & 2.5 & 3.0 & 4.1 & 13.4 & 15.9 & 8.8 & 3.5 & 2.7 & 5.7 \\
\hline 1995 & 3.9 & 3.1 & 2.5 & 2.0 & 2.6 & 3.7 & 5.1 & 18.0 & 13.3 & 8.5 & 5.5 & 4.3 & 6.1 \\
\hline 1996 & 3.3 & 3.0 & 1.8 & 1.9 & 1.5 & 1.0 & 3.4 & 14.3 & 21.7 & 7.8 & 1.7 & 1.2 & 5.2 \\
\hline 1997 & .8 & .9 & .8 & 1.3 & 1.5 & 2.5 & 4.2 & 19.5 & 23.6 & 10.8 & 7.6 & 3.2 & 6.4 \\
\hline 1998 & .6 & .7 & .6 & 1.6 & 1.7 & 2.0 & 4.8 & 18.7 & 15.6 & 7.3 & 7.2 & 2.6 & 5.3 \\
\hline 1999 & 2.6 & & & & & & & & & & & & \\
\hline Average & 2.6 & 2.0 & 1.5 & 1.8 & 2.0 & 2.6 & 4.3 & 17.0 & 17.3 & 7.8 & 4.9 & 3.0 & 5.6 \\
\hline
\end{tabular}


Table 6. Estimated average monthly and annual natural discharges for Tenmile Creek near Rimini, Montana, for water years 1961-90 based on monthly recorded discharge plus natural flow accretion

\begin{tabular}{lccc}
\hline & \multicolumn{3}{c}{ Discharge, in cubic feet per second } \\
\cline { 2 - 4 } Month & Average recorded & $\begin{array}{c}\text { Average natural } \\
\text { flow accretion }\end{array}$ & $\begin{array}{c}\text { Average } \\
\text { natural }\end{array}$ \\
\hline Oct. & 3.5 & 2.6 & 6.1 \\
Nov. & 2.5 & 2.0 & 4.6 \\
Dec. & 1.7 & 1.5 & 3.3 \\
Jan. & 1.5 & 1.8 & 3.3 \\
Feb. & 1.3 & 2.0 & 3.3 \\
Mar. & 2.5 & 2.6 & 5.1 \\
Apr. & 15.6 & 4.3 & 19.9 \\
May & 83.6 & 17.0 & 100.6 \\
June & 72.6 & 17.3 & 89.9 \\
July & 12.7 & 7.8 & 20.5 \\
Aug. & 2.6 & 4.9 & 7.5 \\
Sept. & 2.9 & 3.0 & 5.9 \\
Annual & & & \\
\hline
\end{tabular}


Table 7. Regression results for flow estimation sites, upper Tenmile Creek watershed, Montana

[Abbreviations: $a^{\prime}$, regression constant; $b$, regression coefficient; $\mathrm{R}^{2}$, coefficient of determination; SE, standard error in log units]

\begin{tabular}{|c|c|c|c|c|c|}
\hline \multirow[b]{2}{*}{ Site No. } & \multirow{2}{*}{$\begin{array}{c}\text { Site name } \\
\text { (USGS streamflow-gaging station } \\
\text { number in parentheses) }\end{array}$} & \multicolumn{4}{|c|}{ Regression parameters } \\
\hline & & $\mathbf{a}^{\prime}$ & b & $\mathbf{R}^{2}$ & SE \\
\hline 1 & Monitor Creek at mouth, near Rimini & 0.026 & 1.12 & 0.80 & 0.12 \\
\hline 2 & Tenmile Creek below Monitor Creek, near Rimini & .040 & 1.30 & .99 & .06 \\
\hline 3 & Tenmile Creek above Ruby Creek, near Rimini & .135 & 1.15 & .98 & .07 \\
\hline 6 & Ruby Creek at mouth, near Rimini & .004 & 1.67 & .97 & .14 \\
\hline 7 & Banner Creek above city diversion, near Rimini & .035 & 1.31 & .95 & .17 \\
\hline 11 & Poison Creek at mouth, near Rimini & .015 & .822 & .82 & .20 \\
\hline 12 & Tenmile Creek above city diversion, near Rimini & .203 & 1.23 & .98 & .09 \\
\hline 16 & Beaver Creek tributary 3 near Rimini & .004 & 1.41 & .94 & .18 \\
\hline 18 & Beaver Creek tributary 2 near Rimini & .056 & .728 & .90 & .13 \\
\hline 19 & Beaver Creek tributary 1 near Rimini & .078 & .577 & .89 & .10 \\
\hline 20 & Beaver Creek above city diversion, near Rimini & .346 & .868 & .92 & .15 \\
\hline 22 & Spring Creek at mouth, at Rimini & .050 & .896 & .90 & .16 \\
\hline 24 & Moore's Spring Creek at mouth, near Rimini & .160 & .038 & .01 & .18 \\
\hline 25 & Minnehaha Creek above city diversion, near Rimini & .155 & 1.02 & .91 & .15 \\
\hline 29 & Moose Creek above city diversion, near Rimini & .242 & .509 & .71 & .16 \\
\hline 31 & Bear Gulch at mouth, near Rimini & .022 & .838 & .70 & .21 \\
\hline 32 & Walker Creek above city diversion, near Rimini & .127 & 1.04 & .92 & .15 \\
\hline 34 & Tenmile Creek at Tenmile Water Treatment Plant, near Rimini (06062750) & 1.20 & 1.00 & .99 & .09 \\
\hline
\end{tabular}




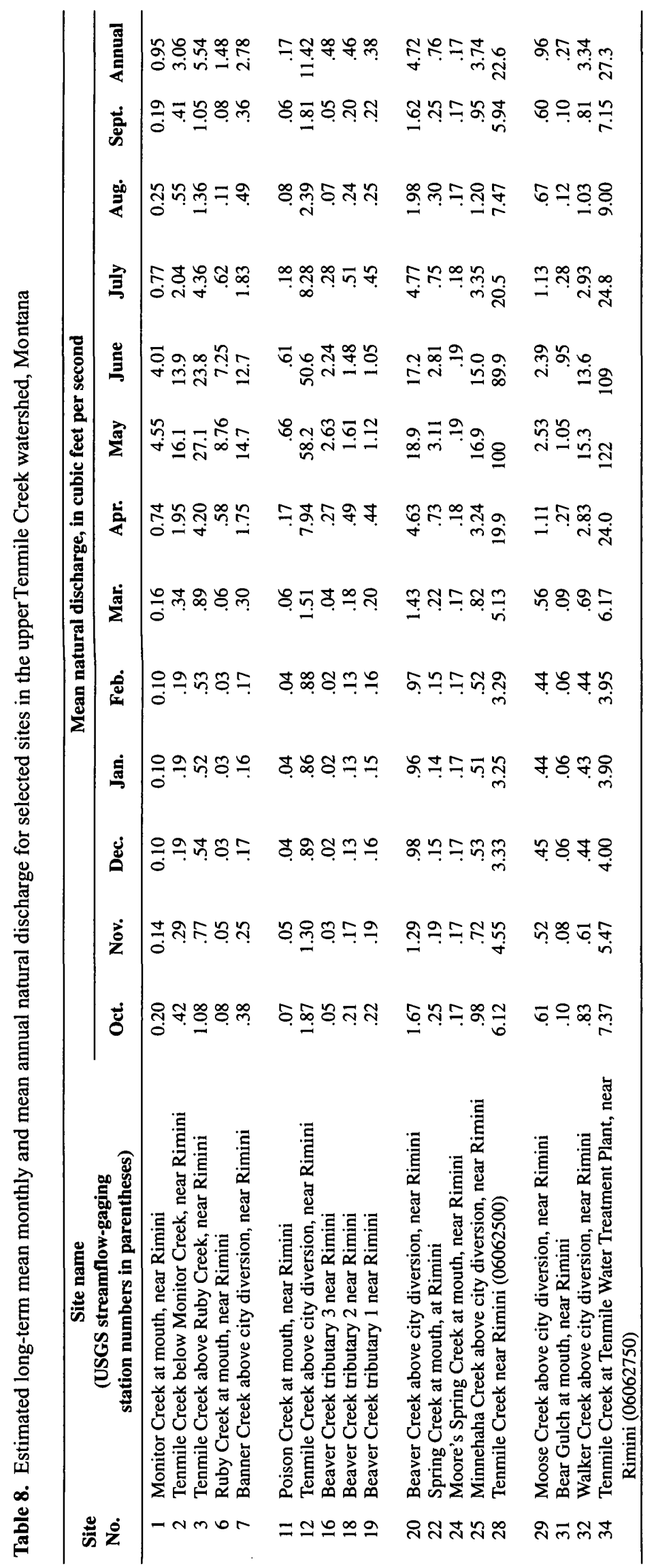


Table 9. Streamflow sampling sites and months of water-quality sample collection during 1997, upper Tenmile Creek watershed, Montana

\begin{tabular}{cll}
\hline $\begin{array}{c}\text { Site } \\
\text { number }\end{array}$ & \multicolumn{1}{c}{$\begin{array}{c}\text { Site name } \\
\text { (USGS streamflow-gaging station } \\
\text { numbers in parenthesis) }\end{array}$} & Month of sample collection \\
\hline 1 & Monitor Creek at mouth, near Rimini & August, October \\
2 & Tenmile Creek below Monitor Creek near Rimini & May, June \\
3 & Tenmile Creek above Ruby Creek, near Rimini & May, June, August, October \\
6 & Ruby Creek at Mouth, near Rimini & May, June, August, October \\
7 & Banner Creek above city diversion, near Rimini & June, August, October \\
9 & Banner Creek tributary near Rimini & August \\
10 & Banner Creek below city diversion, near Rimini & May \\
& & \\
11 & Poison Creek at mouth, near Rimini & May, June, August, October \\
12 & Tenmile Creek above city diversion, near Rimini & June, August, October \\
13 & Tenmile Creek below city diversion, near Rimini & May \\
15 & Beaver Creek above tributary 3, near Rimini & August, October \\
18 & Beaver Creek tributary 2 near Rimini & May, June, August, October \\
20 & Beaver Creek above city diversion, near Rimini & May, June, August, October \\
22 & Spring Creek at mouth, at Rimini & May, June, August, October \\
23 & Tenmile Creek below Spring Creek, at Rimini & May, June, August, October \\
& & \\
25 & Minnehaha Creek above city diversion, near Rimini & May, June, August, October \\
28 & Tenmile Creek near Rimini (06062500) & May, June, August, October \\
29 & Moose Creek above city diversion, near Rimini & May, June, August, October \\
31 & Bear Gulch at mouth, near Rimini & May, June, August, October \\
32 & Walker Creek above city diversion, near Rimini & May, June, August, October \\
34 & Tenmile Creek at Tenmile Water Treatment Plant, near Rimini & May, June, August, October \\
& (06062750) & \\
\hline & &
\end{tabular}


Table 10. Laboratory methods, minimum reporting levels, and water-quality standards for constituents analyzed in water samples from upper Tenmile Creek watershed, Montana

[Abbreviations: $\mu \mathrm{g} / \mathrm{L}$, micrograms per liter; $\mathrm{mg} / \mathrm{L}$, milligrams per liter. Symbol: --, no guideline concentrations established]

\begin{tabular}{|c|c|c|c|c|c|}
\hline \multirow{3}{*}{ Constituent } & \multirow{3}{*}{ Method $^{1}$} & \multirow{3}{*}{$\begin{array}{c}\text { Minimum } \\
\text { reporting level }^{2}\end{array}$} & \multicolumn{3}{|c|}{ Water-quality standard ${ }^{3}$} \\
\hline & & & \multirow{2}{*}{ Human health } & \multicolumn{2}{|c|}{ Aquatic life } \\
\hline & & & & Acute toxicity & Chronic toxicity \\
\hline \multicolumn{6}{|c|}{ MAJOR IONS (dissolved, mg/L) } \\
\hline Calcium & 215.1 & 1 & -- & -- & -. \\
\hline Magnesium & 242.1 & .1 & -- & -- & -- \\
\hline Sodium & 273.1 & .1 & -- & -- & -- \\
\hline Potassium & 258.1 & .1 & -- & -- & -- \\
\hline Sulfate & 300.0 & 1 & -- & -- & -- \\
\hline Chloride & 300.0 & 1 & -- & 860 & 230 \\
\hline Fluoride & 300.0 & .1 & 4 & -- & -- \\
\hline \multicolumn{6}{|c|}{ NUTRIENTS (dissolved, mg/L) } \\
\hline Nitrate $^{4}$ & 300.0 & .01 & 10 & -- & -- \\
\hline Nitrite $^{4}$ & 300.0 & .01 & 1 & - & - \\
\hline Ammonia ${ }^{4}$ & 350.3 & .05 & -- & ${ }^{5} 9.5$ & ${ }^{5} 1.9$ \\
\hline Phosphate $^{4}$ & 365.3 & .01 & -- & -. & -- \\
\hline Phosphorus, ortho ${ }^{4}$ & 365.3 & .01 & -- & -- & -- \\
\hline \multicolumn{6}{|c|}{ TRACE ELEMENTS $(\mu \mathrm{g} / \mathrm{L})^{6}$} \\
\hline Aluminum ${ }^{7}$ & 200.7 & 100 & - & 750 & 87 \\
\hline Arsenic & 206.2 & 3 & 18 & 360 & 190 \\
\hline Cadmium $^{8}$ & 213.2 & .1 & 5 & 3.9 & 1.1 \\
\hline 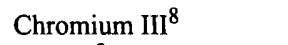 & 200.7 & 1 & 100 & 1,700 & 210 \\
\hline Copper $^{8}$ & 200.7 & 1 & 1,000 & 18 & 12 \\
\hline Iron 9 & 200.7 & 10 & 300 & -- & 1,000 \\
\hline Lead $^{8}$ & 239.2 & 3 & 15 & 82 & 3.2 \\
\hline Manganese $^{9}$ & 200.7 & 5 & 50 & -- & -- \\
\hline Mercury & 245.2 & .6 & .14 & 2.4 & .012 \\
\hline Nickel $^{8}$ & 200.7 & 20 & 100 & 1,400 & 160 \\
\hline Selenium & 270.2 & 1 & 50 & 20 & 5 \\
\hline Silver ${ }^{8}$ & 200.7 & 3 & -- & 4.1 & -- \\
\hline Zinc $^{8}$ & 200.7 & ${ }^{10} 10$ & 5,000 & 120 & 110 \\
\hline
\end{tabular}

${ }_{1}^{1}$ U.S. Environmental Protection Agency (1983, 1991); Montana Tunnels Mining, Inc. (1997).

${ }^{2}$ Minimum reporting level for major ion, nutrient, and trace element analyses by Montana Tunnels Laboratory. Minimum reporting levels for replicate analyses by U.S. Geological Survey (for quality control) may differ.

${ }^{3}$ Montana Department of Environmental Quality (1995).

${ }^{4}$ A plant nutrient, excessive amounts of which may cause violations of Administrative Rules of Montana (ARM) 16.20.633.(1)(e).

${ }^{5}$ Toxicity standards for ammonia are based on a pH of 7.7 and a temperature of 11.5 degrees Celsius.

${ }^{6}$ Aquatic-life standards refer to total-recoverable concentrations, except for the standard for aluminum, which refers to the dissolved concentration.

${ }^{7}$ Montana aquatic-life standard for aluminum concentrations applicable only for $\mathrm{pH}$ between 6.5 and 9.0 .

${ }^{8}$ Aquatic-life standards are hardness dependent. Standards listed are based on total hardness of $100 \mathrm{mg} / \mathrm{L}$ as $\mathrm{CaCO}_{3}$. Equations for hardnessdependent criteria are presented in table 15.

${ }^{9}$ Human-health standard is for aesthetic purposes only.

${ }^{10}$ Minimum reporting level revised upward to $100 \mu \mathrm{g} / \mathrm{L}$ as a result of zinc contamination of sample preservative. 
Table 11. Bottom-sediment sampling sites and depths, Chessman Reservoir, upper Tenmile Creek watershed, Montana

\begin{tabular}{llc}
\hline Site No. & \multicolumn{1}{c}{ Site name } & $\begin{array}{c}\text { Sample depth, in inches below } \\
\text { sediment surface }\end{array}$ \\
\hline R1 & Chessman Reservoir Southwest & $0-4$ \\
R2A & Chessman Reservoir Northeast & $0-7$ \\
R2B & Chessman Reservoir Northeast & $7-9$ \\
R3 & Wetland above Chessman Reservoir & $0-9$ \\
R4 & Chessman Reservoir Southeast & $0-6$ \\
\hline
\end{tabular}


Table 12. Field-measured parameters and concentrations of major ions and nutrients in streams in the upper Tenmile Creek watershed, Montana

[Abbreviations: ${ }^{\circ} \mathrm{C}$, degrees Celsius; inst., instantaneous; $\mu \mathrm{S} / \mathrm{cm}$, microsiemens per centimeter at $25^{\circ} \mathrm{C}$; $\mathrm{mg} / \mathrm{L}$, milligrams per liter. Symbols: <, less than; --, no data. BLANKS are quality-control samples of deionized water]

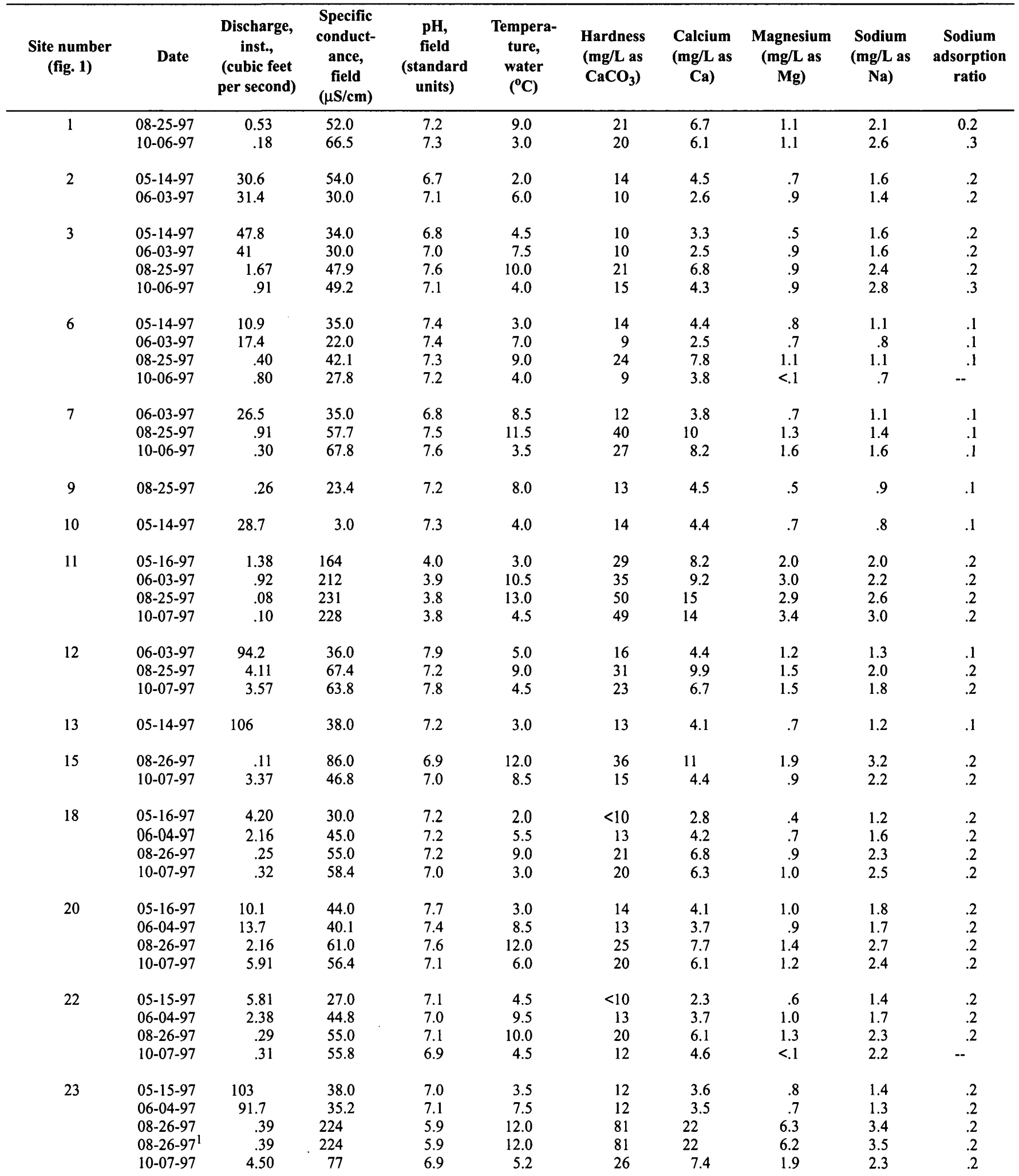


Table 12. Field-measured parameters and concentrations of major ions and nutrients in streams in the upper Tenmile Creek watershed, Montana (Continued)

\begin{tabular}{|c|c|c|c|c|c|c|c|c|c|c|c|}
\hline $\begin{array}{c}\text { Potassium, } \\
\text { dissolved } \\
\text { (mg/L as } \\
\text { K) }\end{array}$ & $\begin{array}{c}\text { Bicar- } \\
\text { bonate } \\
\text { (mg/Las } \\
\mathrm{HCO}_{3} \text { ) }\end{array}$ & $\begin{array}{c}\text { Alka- } \\
\text { linity } \\
(\mathrm{mg} / \mathrm{Las} \\
\mathrm{CaCO}_{3}\end{array}$ & $\begin{array}{c}\text { Sulfate, } \\
\text { dissolved } \\
(\mathrm{mg} / \mathrm{L} \text { as } \\
\left.\mathrm{SO}_{4}\right)\end{array}$ & $\begin{array}{c}\text { Chloride, } \\
\text { dissolved } \\
(\mathrm{mg} / \mathrm{L} \text { as } \\
\mathrm{Cl})\end{array}$ & $\begin{array}{l}\text { Fluoride, } \\
\text { dissolved } \\
\text { (mg/L as F) }\end{array}$ & $\begin{array}{c}\text { Nitrate, } \\
\text { dissolved } \\
\text { (mg/L as } \\
\mathrm{N})\end{array}$ & $\begin{array}{c}\text { Nitrite, } \\
\text { dissolved } \\
(\mathrm{mg} / \mathrm{L} \text { as } \\
\mathrm{N})\end{array}$ & $\begin{array}{c}\text { Ammonia, } \\
\text { dissolved } \\
(\mathrm{mg} / \mathrm{L} \text { as } \mathrm{N})\end{array}$ & $\begin{array}{l}\text { Phosphorus, } \\
\text { total } \\
\text { (mg/L as P) }\end{array}$ & $\begin{array}{l}\text { Phosphate, } \\
\text { ortho, } \\
\text { dissolved } \\
(\mathrm{mg} / \mathrm{L} \text { as } \\
\left.\mathrm{PO}_{4}\right)\end{array}$ & $\begin{array}{l}\text { Site number } \\
\quad \text { (fig. 1) }\end{array}$ \\
\hline 1.2 & 13 & 10 & 11 & $<1.0$ & 0.14 & 0.01 & $<0.01$ & $<0.05$ & 0.01 & $<0.01$ & 1 \\
\hline 1.6 & 13 & 11 & 17 & $<1.0$ & .13 & .01 & $<.01$ & $<.05$ & .01 & $<.01$ & \\
\hline 1.2 & -- & 6 & 9.9 & $<1.0$ & $<.10$ & .07 & $<.01$ & $<.05$ & .03 & $<.01$ & 2 \\
\hline 1.0 & - & 6 & 6.8 & $<1.0$ & $<.10$ & .06 & $<.01$ & $<.05$ & $<.01$ & $<.01$ & \\
\hline 1.2 & - & 6 & 7.0 & $<1.0$ & $<.10$ & .05 & $<.01$ & $<.05$ & .03 & $<.01$ & 3 \\
\hline 1.0 & -- & 8 & 5.9 & $<1.0$ & $<.10$ & .01 & $<.01$ & $<.05$ & .01 & $<.01$ & \\
\hline 1.0 & 15 & 12 & 7.3 & $<1.0$ & $<.10$ & $<.01$ & $<.01$ & $<.05$ & .01 & $<.01$ & \\
\hline 1.1 & 16 & 13 & 8.6 & $<1.0$ & .11 & $<.01$ & $<.01$ & .05 & .01 & $<.01$ & \\
\hline$<.1$ & -- & 12 & 2.6 & $<1.0$ & $<.10$ & .04 & $<.01$ & $<.05$ & .02 & $<.01$ & 6 \\
\hline .6 & -- & 8 & 2.1 & $<1.0$ & .10 & $<.01$ & $<.01$ & $<.05$ & .02 & $<.01$ & \\
\hline .5 & 19 & 16 & 2.9 & $<1.0$ & $<.10$ & .03 & $<.01$ & $<.05$ & .01 & $<.01$ & \\
\hline .7 & 11 & 9 & 2.8 & $<1.0$ & $<.10$ & $<.01$ & $<.01$ & $<.05$ & .01 & $<.01$ & \\
\hline .7 & .. & 10 & 4.5 & $<1.0$ & $<.10$ & .01 & $<.01$ & $<.05$ & .03 & $<.01$ & 7 \\
\hline .6 & 25 & 21 & 6.6 & $<1.0$ & $<.10$ & $<.01$ & $<.01$ & $<.05$ & .01 & $<.01$ & \\
\hline .7 & 27 & 22 & 9.3 & $<1.0$ & $<.10$ & .10 & $<.01$ & $<.05$ & $<.01$ & $<.01$ & \\
\hline .7 & 7 & 6 & 3.1 & $<1.0$ & .68 & .36 & $<.01$ & $<.05$ & .01 & $<.01$ & 9 \\
\hline .8 & -- & 11 & 4.4 & $<1.0$ & $<.10$ & .02 & $<.01$ & $<.05$ & .05 & $<.01$ & 10 \\
\hline 1.8 & -. & -- & 55 & $<1.0$ & .13 & .06 & $<.01$ & $<.05$ & .09 & $<.01$ & 11 \\
\hline 1.5 & -- & -- & 71 & $<1.0$ & .16 & .07 & $<.01$ & $<.05$ & .02 & $<.01$ & \\
\hline 1.6 & .. & .- & 94 & $<1.0$ & .17 & .10 & $<.01$ & $<.05$ & $<.01$ & $<.01$ & \\
\hline 1.7 & - & -- & 92 & $<1.0$ & .26 & .10 & $<.01$ & $<.05$ & .01 & $<.01$ & \\
\hline .8 & -- & 8 & 5.8 & $<1.0$ & $<.10$ & .01 & $<.01$ & $<.05$ & .01 & $<.01$ & 12 \\
\hline .9 & 21 & 17 & 13 & $<1.0$ & $<.10$ & .03 & $<.01$ & $<.05$ & .02 & $<.01$ & \\
\hline 1.0 & 17 & 14 & 14 & $<1.0$ & $<.10$ & .01 & $<.01$ & $<.05$ & .01 & $<.01$ & \\
\hline .9 & -- & 8 & 6.9 & $<1.0$ & $<.10$ & .03 & $<.01$ & $<.05$ & .04 & $<.01$ & 13 \\
\hline 1.1 & 37 & 31 & 8.8 & $<1.0$ & $<.10$ & .05 & $<.01$ & .07 & .16 & .04 & 15 \\
\hline 1.2 & 15 & 13 & 8.1 & $<1.0$ & $<.10$ & .03 & $<.01$ & $<.05$ & .04 & $<.01$ & \\
\hline 1.0 & -- & 9 & 4.5 & $<1.0$ & $<.10$ & .03 & $<.01$ & $<.05$ & .02 & $<.01$ & 18 \\
\hline 1.1 & 10 & 8 & 11 & $<1.0$ & $<.10$ & .03 & $<.01$ & $<.05$ & .02 & .01 & \\
\hline 1.2 & 17 & 14 & 11 & $<1.0$ & .60 & .04 & $<.01$ & $<.05$ & .01 & $<.01$ & \\
\hline 1.6 & 18 & 15 & 11 & $<1.0$ & $<.10$ & .03 & $<.01$ & $<.05$ & $<.01$ & $<.01$ & \\
\hline 1.0 & -. & 12 & 7.8 & $<1.0$ & $<.10$ & .07 & $<.01$ & $<.05$ & .03 & $<.01$ & 20 \\
\hline 1.0 & 12 & 10 & 7.0 & $<1.0$ & $<.10$ & .03 & $<.01$ & $<.05$ & .02 & $<.01$ & \\
\hline 1.2 & 23 & 18 & 9.7 & $<1,0$ & .57 & .05 & $<.01$ & $<.05$ & .02 & $<.01$ & \\
\hline 1.3 & 19 & 16 & 9.9 & $<1.0$ & $<.10$ & $<.01$ & $<.01$ & $<.05$ & .03 & $<.01$ & \\
\hline .9 & -- & 6 & 5.4 & $<1.0$ & $<.10$ & .07 & $<.01$ & $<.05$ & .04 & $<.01$ & 22 \\
\hline 1.2 & 8 & 7 & 13 & $<1.0$ & $<.10$ & $<.01$ & $<.01$ & $<.05$ & .01 & $<.01$ & \\
\hline 1.2 & 13 & 11 & 13 & $<1.0$ & $<.10$ & $<.01$ & $<.01$ & $<.05$ & .02 & $<.01$ & \\
\hline 1.3 & 13 & 11 & 13 & $<1.0$ & $<.10$ & .02 & $<.01$ & $<.05$ & .02 & $<.01$ & \\
\hline 1.0 & .. & 9 & 7.2 & $<1.0$ & $<.10$ & .03 & $<.01$ & $<.05$ & .03 & $<.01$ & 23 \\
\hline .8 & 9 & 8 & 7.1 & $<1.0$ & $<.10$ & $<.01$ & $<.01$ & $<.05$ & .02 & $<.01$ & \\
\hline 1.5 & $<5$ & $<5$ & 97 & $<1.0$ & .15 & .12 & $<.01$ & $<.05$ & .06 & $<.01$ & \\
\hline 1.6 & $<5$ & $<5$ & 99 & $<1.0$ & .18 & .11 & $<.01$ & $<.05$ & .06 & $<.01$ & \\
\hline 1.1 & 15 & 13 & 19 & $<1.0$ & $<.10$ & $<.01$ & .02 & $<.05$ & .05 & $<.01$ & \\
\hline
\end{tabular}


Table 12. Field-measured parameters and concentrations of major ions and nutrients in streams in the upperTenmile Creek watershed, Montana (Continued)

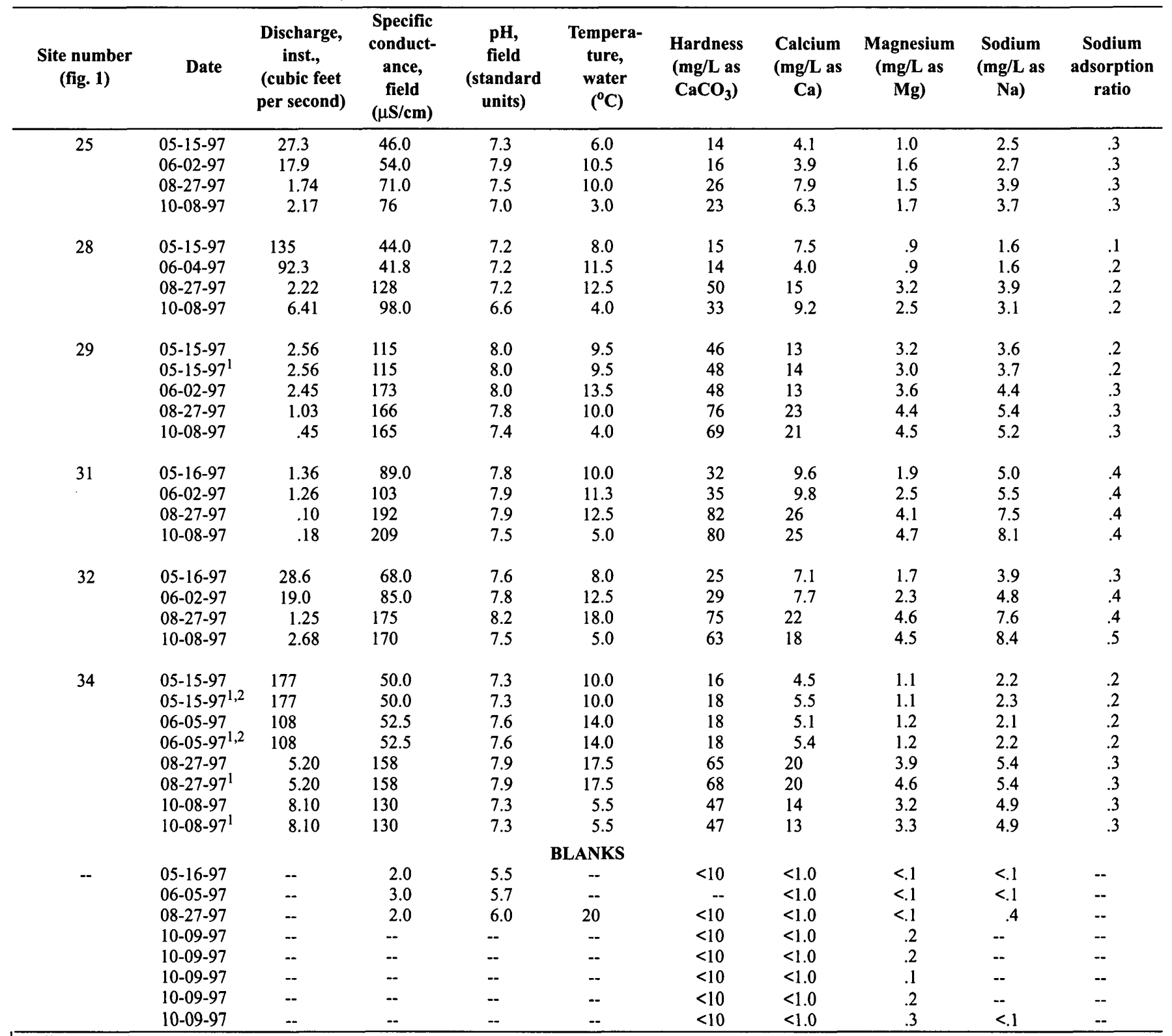

'Replicate sample.

${ }^{2}$ Replicate sample analyzed by USGS National Water Quality Laboratory. 
Table 12. Field-measured parameters and concentrations of major ions and nutrients in streams in upper Tenmile Creek watershed, Montana (Continued)

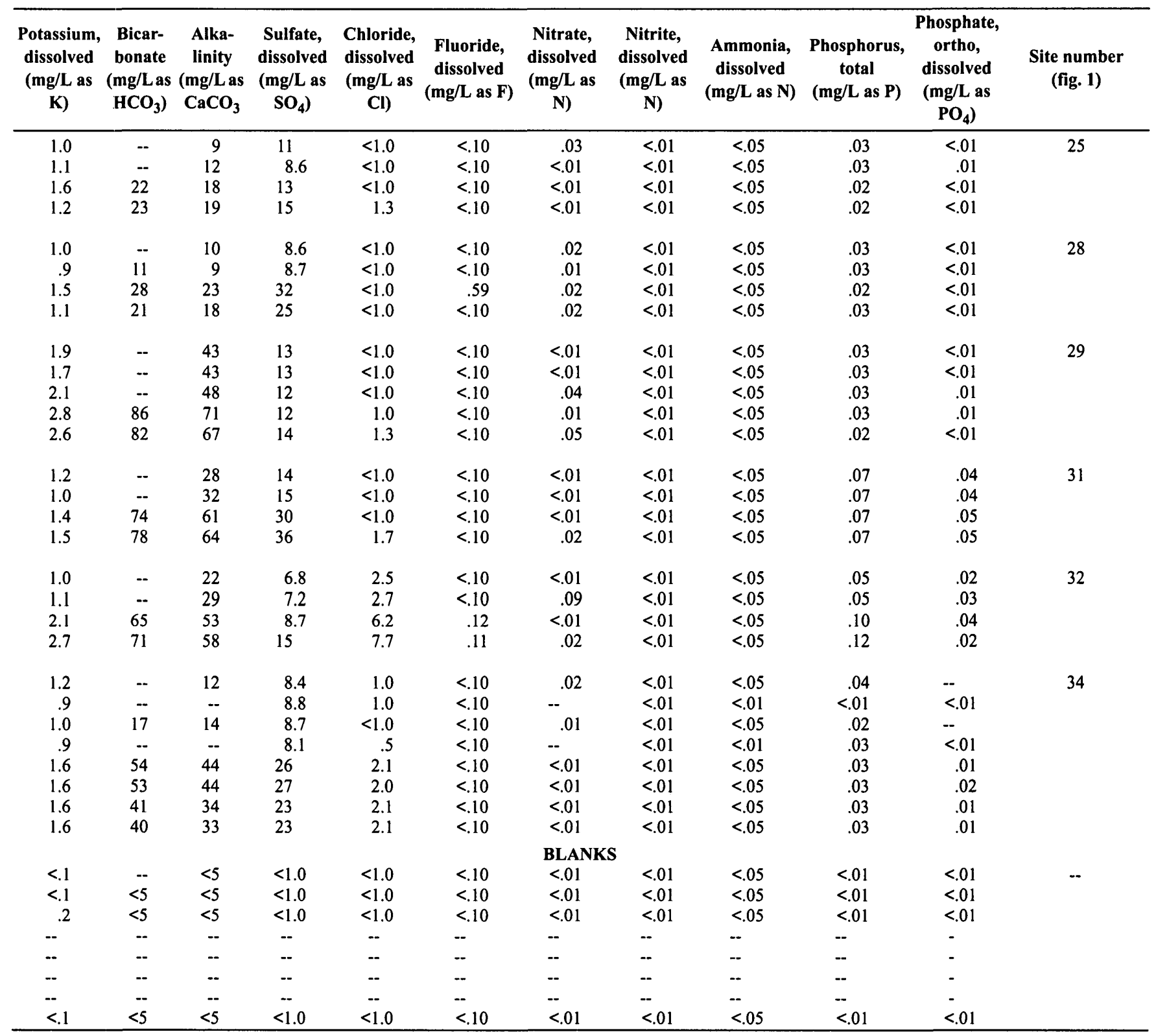


Table 13. Concentrations of trace elements and suspended sediment in streams in the upperTenmile Creek watershed, Montana

[Samples analyzed by Montana Tunnels Laboratory unless otherwise indicated. Shaded value indicates exceedances of human health standard, except for iron and manganese, which are standards for aesthetic purposes. Bold type indicates exceedance of chronic aquatic-life standard. Bold italics indicate acute aquatic-life standard also exceeded. Standards are shown in table 10. Identical sample dates indicate replicate samples analyzed to evaluate reproducibility of results.

Abbreviations: inst., instantaneous; $\mu \mathrm{g} / \mathrm{L}$, micrograms per liter; $\mathrm{mg} / \mathrm{L}$, milligrams per liter; $\mathrm{mm}$, millimeter; rec., recoverable. Symbols: <, less than; --, no data. BLANKS are quality-control samples of deionized water]

\begin{tabular}{|c|c|c|c|c|c|c|c|c|c|c|}
\hline $\begin{array}{c}\text { Site } \\
\text { number } \\
\text { (fig. 1) }\end{array}$ & Date & $\begin{array}{c}\text { Dis- } \\
\text { charge, } \\
\text { inst., } \\
\text { (cubic feet } \\
\text { per } \\
\text { second) }\end{array}$ & $\begin{array}{l}\text { Aluminum, } \\
\text { total rec. } \\
(\mu \mathrm{g} / \mathrm{L} \text { as } \mathrm{Al})\end{array}$ & $\begin{array}{c}\text { Arsenic, } \\
\text { total rec. } \\
(\mu \mathrm{g} / \mathrm{L} \text { as } \\
\text { As })\end{array}$ & $\begin{array}{l}\text { Cad- } \\
\text { mium, } \\
\text { total rec. } \\
(\mu \mathrm{g} / \mathrm{L} \text { as } \\
\text { Cd })\end{array}$ & $\begin{array}{c}\text { Cad- } \\
\text { mium, } \\
\text { dissolved } \\
(\mu \mathrm{g} / \mathrm{L} \text { as } \\
\text { Cd })\end{array}$ & $\begin{array}{c}\text { Chro- } \\
\text { mium, } \\
\text { total rec. } \\
(\mu \mathrm{g} / \mathrm{L} \text { as } \\
\text { Cr })\end{array}$ & $\begin{array}{c}\text { Copper, } \\
\text { total rec. } \\
(\mu \mathrm{g} / \mathrm{L} \text { as } \\
\mathrm{Cu})\end{array}$ & $\begin{array}{c}\text { Copper, } \\
\text { dissolved } \\
(\mu \mathrm{g} / \mathrm{L} \text { as } \\
\text { Cu })\end{array}$ & $\begin{array}{c}\text { Iron, } \\
\text { total rec. } \\
(\mu \mathrm{g} / \mathrm{L} \text { as } \\
\text { Fe })\end{array}$ \\
\hline \multirow[t]{2}{*}{1} & $08-25-97$ & 0.53 & 100 & $<3$ & 0.2 & 0.1 & $<1$ & 12 & 5 & 100 \\
\hline & $10-06-97$ & .18 & $<100$ & $<3$ & .2 & .2 & $<1$ & $<1$ & $<1$ & 70 \\
\hline \multirow[t]{2}{*}{2} & $05-14-97$ & 30.6 & 760 & $<3$ & .6 & .6 & $<1$ & 19 & 4 & 420 \\
\hline & 06-03-97 & 31.4 & 360 & $<3$ & .2 & .2 & $<1$ & 23 & 5 & 160 \\
\hline \multirow[t]{4}{*}{3} & $05-14-97$ & 47.8 & 770 & $<3$ & .3 & .3 & $<1$ & 11 & 4 & 460 \\
\hline & $06-03-97$ & 41.0 & 370 & $<3$ & .2 & .2 & $<1$ & 19 & 5 & 170 \\
\hline & $08-25-97$ & 1.67 & $<100$ & $<3$ & $<.1$ & $<.1$ & $<1$ & 4 & 4 & 110 \\
\hline & $10-06-97$ & .91 & $<100$ & $<3$ & $<.1$ & $<.1$ & $<1$ & $<1$ & $<1$ & 80 \\
\hline \multirow[t]{4}{*}{6} & $05-14-97$ & 10.9 & 480 & 6 & .2 & .2 & $<1$ & 9 & 4 & 270 \\
\hline & $06-03-97$ & 17.4 & 310 & $<3$ & $<.1$ & $<.1$ & $<1$ & 21 & 4 & 220 \\
\hline & $08-25-97$ & .40 & $<100$ & 7 & $<.1$ & $<.1$ & $<1$ & 3 & 5 & 70 \\
\hline & $10-06-97$ & .80 & 150 & 3 & $<.1$ & $<.1$ & $<1$ & 16 & 2 & 140 \\
\hline \multirow[t]{3}{*}{7} & $06-03-97$ & 26.5 & 320 & $<3$ & .2 & .3 & $<1$ & 16 & 7 & 250 \\
\hline & $08-25-97$ & .91 & $<100$ & $<3$ & $<.1$ & $<.1$ & $<1$ & 3 & 1 & 250 \\
\hline & $10-06-97$ & .30 & $<100$ & $<3$ & $<.1$ & $<.1$ & $<1$ & $<1$ & $<1$ & 100 \\
\hline 9 & $08-25-97$ & .26 & 210 & $<3$ & $<.1$ & $<.1$ & $<1$ & $<1$ & $<1$ & 100 \\
\hline 10 & $05-14-97$ & 28.7 & 730 & $<3$ & .4 & .2 & $<1$ & 29 & 5 & 1,100 \\
\hline \multirow[t]{4}{*}{11} & $05-16-97$ & 1.38 & 2,000 & 180 & 25 & 21 & $<1$ & 240 & 210 & 1,600 \\
\hline & 06-03-97 & .92 & 2,400 & 11 & 30 & 30 & $<1$ & 420 & 410 & 630 \\
\hline & $08-25-97$ & .08 & 1,900 & 14 & 30 & 30 & $<1$ & 310 & 320 & 420 \\
\hline & $10-07-97$ & .10 & 1,700 & 11 & 30 & 26 & $<1$ & 270 & 250 & 430 \\
\hline \multirow[t]{3}{*}{12} & $06-03-97$ & 94.2 & 390 & $<3$ & .6 & .6 & $<1$ & 19 & 9 & 230 \\
\hline & $08-25-97$ & 4.11 & $<100$ & 8 & 1.8 & 1.8 & $<1$ & 10 & 8 & 140 \\
\hline & $10-07-97$ & 3.57 & 140 & 5 & 1.7 & 1.7 & $<1$ & 37 & 7 & 170 \\
\hline 13 & $05-14-97$ & 106 & 770 & 8 & 1.1 & 1.0 & $<1$ & 26 & 7 & 590 \\
\hline \multirow[t]{2}{*}{15} & $08-26-97$ & .11 & $<100$ & 19 & .5 & .4 & $<1$ & 150 & 120 & 3,100 \\
\hline & $10-07-97$ & 3.37 & 140 & 5 & .4 & .3 & $<1$ & 430 & 210 & 730 \\
\hline \multirow[t]{4}{*}{18} & $05-16-97$ & 4.20 & 300 & 27 & 2.5 & 1.6 & $<1$ & 53 & 16 & 430 \\
\hline & 06-04-97 & 2.16 & 190 & 23 & 6 & 5 & $<1$ & 49 & 30 & 320 \\
\hline & $08-26-97$ & .25 & $<100$ & 9 & 2.4 & 2.1 & $<1$ & 9 & 6 & 80 \\
\hline & $10-07-97$ & .32 & $<100$ & 6 & 1.8 & 1.8 & $<1$ & 6 & 6 & 30 \\
\hline
\end{tabular}


Table 13. Concentrations of trace elements and suspended sediment in streams in the upper Tenmile Creek watershed, Montana (Continued)

\begin{tabular}{|c|c|c|c|c|c|c|c|c|c|c|c|}
\hline $\begin{array}{c}\text { Lead, } \\
\text { total } \\
\text { rec. } \\
(\mu \mathrm{g} / \mathrm{L} \text { as } \\
\mathrm{Pb})\end{array}$ & $\begin{array}{c}\text { Lead, } \\
\text { dissolved } \\
(\mu \mathbf{g} / \mathbf{L} \text { as } \\
\mathbf{P b})\end{array}$ & $\begin{array}{c}\text { Manga- } \\
\text { nese, } \\
\text { total } \\
\text { rec. } \\
(\mu \mathrm{g} / \mathrm{L} \text { as } \\
\text { Mn) }\end{array}$ & $\begin{array}{l}\text { Mer- } \\
\text { cury, } \\
\text { total } \\
\text { rec. } \\
(\mu \mathrm{g} / \mathrm{L} \text { as } \\
\mathrm{Hg})\end{array}$ & $\begin{array}{c}\text { Nickel, } \\
\text { total } \\
\text { rec. } \\
(\mu \mathrm{g} / \mathrm{L} \text { as } \\
\mathrm{Ni})\end{array}$ & $\begin{array}{c}\text { Sele- } \\
\text { nium, } \\
\text { total } \\
\text { rec. } \\
(\mu \mathrm{g} / \mathrm{L} \\
\text { as Se })\end{array}$ & $\begin{array}{c}\text { Silver, } \\
\text { total rec. } \\
(\mu \mathrm{g} / \mathrm{L} \text { as } \\
\text { Ag) }\end{array}$ & $\begin{array}{c}\text { Zinc, } \\
\text { total } \\
\text { rec. } \\
(\mu \mathrm{g} / \mathrm{L} \text { as } \\
\mathrm{Zn})\end{array}$ & $\begin{array}{c}\text { Zinc, } \\
\text { dissolved } \\
(\mu \mathrm{g} / \mathrm{L} \text { as } \\
\mathrm{Zn})\end{array}$ & $\begin{array}{c}\text { Sedi- } \\
\text { ment, } \\
\text { sus- } \\
\text { pended } \\
(\mathrm{mg} / \mathrm{L})\end{array}$ & $\begin{array}{c}\text { Sediment, } \\
\text { sus- } \\
\text { pended } \\
\text { sieve } \\
\text { diameter } \\
<0.062 \mathrm{~mm} \\
\text { (percent) }\end{array}$ & $\begin{array}{c}\text { Site } \\
\text { number } \\
\text { (fig. 1) }\end{array}$ \\
\hline 7 & $<3$ & 13 & $<0.6$ & $<20$ & $<1$ & $<3$ & $<100$ & $<100$ & 4 & 91 & 1 \\
\hline$<3$ & $<3$ & 12 & $<.6$ & $<20$ & $<1$ & $<3$ & $<100$ & $<100$ & 3 & 64 & \\
\hline 6 & $<3$ & 42 & $<.6$ & $<20$ & -- & $<3$ & $<100$ & $<100$ & 27 & 73 & 2 \\
\hline$<3$ & $<3$ & 19 & $<.6$ & $<20$ & $<1$ & $<3$ & $<100$ & $<100$ & 8 & 68 & \\
\hline 6 & $<3$ & 37 & $<.6$ & $<20$ & - & $<3$ & $<100$ & $<100$ & 29 & 74 & 3 \\
\hline$<3$ & $<3$ & 14 & $<.6$ & $<20$ & $<1$ & $<3$ & $<100$ & $<100$ & 8 & 61 & \\
\hline$<3$ & $<3$ & $<5$ & $<.6$ & $<20$ & $<1$ & $<3$ & $<100$ & $<100$ & 2 & 86 & \\
\hline$<3$ & $<3$ & $<5$ & $<.6$ & $<20$ & $<1$ & $<3$ & $<100$ & $<100$ & 2 & 74 & \\
\hline 7 & $<3$ & 10 & $<.6$ & $<20$ & - & $<3$ & $<100$ & $<100$ & 9 & 84 & 6 \\
\hline$<3$ & $<3$ & 12 & $<.6$ & $<20$ & $<1$ & $<3$ & $<100$ & $<10$ & 13 & 51 & \\
\hline$<3$ & $<3$ & $<5$ & $<.6$ & $<20$ & $<1$ & $<3$ & $<100$ & $<100$ & 2 & 90 & \\
\hline$<3$ & $<3$ & $<5$ & $<.6$ & $<20$ & $<1$ & $<3$ & $<100$ & $<100$ & 4 & 90 & \\
\hline 4 & 5 & 34 & 5.8 & $<20$ & $<1$ & $<3$ & $<100$ & $<100$ & 7 & 80 & 7 \\
\hline$<3$ & $<3$ & 27 & $<.6$ & $<20$ & $<1$ & $<3$ & $<100$ & $<100$ & 2 & 93 & \\
\hline$<3$ & $<3$ & 11 & $<.6$ & $<20$ & $<1$ & $<3$ & $<100$ & $<100$ & 2 & 68 & \\
\hline$<3$ & $<3$ & $<5$ & $<.6$ & $<20$ & $<1$ & $<3$ & $<100$ & $<100$ & 6 & 89 & 9 \\
\hline 7 & $<3$ & 150 & $<.6$ & $<20$ & -- & $<3$ & $<100$ & $<100$ & 70 & 60 & 10 \\
\hline 140 & 46 & 1,500 & $<.6$ & $<20$ & -- & $<3$ & 2,300 & 2,300 & 150 & 28 & 11 \\
\hline 52 & 51 & 1,800 & $<.6$ & $<20$ & 3 & $<3$ & 3,700 & 3,900 & 7 & 61 & \\
\hline 81 & 76 & 1,700 & $<.6$ & $<20$ & $<1$ & $<3$ & 3,000 & 3,000 & 1 & 75 & \\
\hline 66 & 71 & 1,600 & $<.6$ & $<20$ & $<1$ & $<3$ & 3,200 & 3,200 & 3 & 73 & \\
\hline$<3$ & $<3$ & 38 & $<.6$ & $<20$ & $<1$ & $<3$ & 120 & 120 & 9 & 60 & 12 \\
\hline 7 & $<3$ & 10 & $<.6$ & $<20$ & $<1$ & $<3$ & 460 & 440 & 11 & 78 & \\
\hline 6 & $<3$ & 100 & $<.6$ & $<20$ & $<1$ & $<3$ & 440 & 420 & 4 & 84 & \\
\hline 15 & $<3$ & 82 & $<.6$ & $<20$ & - & $<3$ & 220 & 170 & 29 & 58 & 13 \\
\hline$<3$ & $<3$ & 370 & $<.6$ & $<20$ & -- & $<3$ & $<100$ & $<100$ & 10 & 90 & 15 \\
\hline 4 & $<3$ & 90 & $<.6$ & $<20$ & $<1$ & $<3$ & $<100$ & $<100$ & 7 & 87 & \\
\hline 33 & $<3$ & 69 & $<.6$ & $<20$ & -- & $<3$ & 300 & 240 & 19 & 40 & 18 \\
\hline 13 & $<3$ & 75 & $<.6$ & $<20$ & $<1$ & $<3$ & 700 & 690 & 10 & 29 & \\
\hline 5 & $<3$ & 10 & $<.6$ & $<20$ & -- & $<3$ & 380 & 360 & -- & - & \\
\hline$<3$ & $<3$ & $<5$ & $<.6$ & $<20$ & $<1$ & $<3$ & 400 & 400 & 2 & 40 & \\
\hline
\end{tabular}


Table 13. Concentrations of trace elements and suspended sediment in streams in the upperTenmile Creek watershed, Montana (Continued)

\begin{tabular}{|c|c|c|c|c|c|c|c|c|c|c|}
\hline $\begin{array}{c}\text { Site } \\
\text { number } \\
\text { (fig. 1) }\end{array}$ & Date & $\begin{array}{c}\text { Dis- } \\
\text { charge, } \\
\text { inst., } \\
\text { (cubic feet } \\
\text { per } \\
\text { second) }\end{array}$ & $\begin{array}{c}\text { Aluminum, } \\
\text { total rec. } \\
(\mu \mathrm{g} / \mathrm{L} \text { as } \mathrm{Al})\end{array}$ & $\begin{array}{c}\text { Arsenic, } \\
\text { total rec. } \\
(\mu \mathrm{g} / \mathrm{L} \text { as } \\
\text { As })\end{array}$ & $\begin{array}{l}\text { Cad- } \\
\text { mium, } \\
\text { total rec. } \\
(\mu \mathrm{g} / \mathrm{L} \text { as } \\
\text { Cd) }\end{array}$ & $\begin{array}{l}\text { Cad- } \\
\text { mium, } \\
\text { dissolved } \\
(\mu \mathrm{g} / \mathrm{L} \text { as } \\
\text { Cd })\end{array}$ & $\begin{array}{l}\text { Chro- } \\
\text { mium, } \\
\text { total rec. } \\
(\mu \mathrm{g} / \mathrm{L} \text { as } \\
\text { Cr })\end{array}$ & $\begin{array}{c}\text { Copper, } \\
\text { total rec. } \\
(\mu \mathrm{g} / \mathrm{L} \text { as } \\
\mathrm{Cu})\end{array}$ & $\begin{array}{c}\text { Copper, } \\
\text { dissolved } \\
(\mu \mathrm{g} / \mathrm{L} \text { as } \\
\mathrm{Cu})\end{array}$ & $\begin{array}{c}\text { Iron, } \\
\text { total rec. } \\
(\mu \mathrm{g} / \mathrm{L} \text { as } \\
\mathrm{Fe})\end{array}$ \\
\hline \multirow{4}{*}{20} & $05-16-97$ & 10.1 & 300 & 10 & .2 & .2 & $<1$ & 25 & 16 & 210 \\
\hline & $06-04-97$ & 13.7 & 450 & 5 & .2 & .2 & $<1$ & 20 & 15 & 250 \\
\hline & $08-26-97$ & 2.16 & 120 & 4 & .3 & .2 & $<1$ & 87 & 14 & 340 \\
\hline & $10-07-97$ & 5.91 & 130 & 4 & .4 & .3 & $<1$ & 240 & 130 & 600 \\
\hline \multirow[t]{4}{*}{22} & $05-15-97$ & 5.81 & 850 & 14 & 1.8 & 1 & $<1$ & 46 & 14 & 420 \\
\hline & $06-04-97$ & 2.38 & 500 & 6 & 1.8 & 1.5 & $<1$ & 22 & 15 & 170 \\
\hline & $08-26-97$ & .29 & 120 & 8 & 1.6 & 1.4 & $<1$ & 19 & 8 & 60 \\
\hline & $10-07-97$ & .31 & 120 & 7 & 1.5 & 1.2 & $<1$ & 39 & 8 & 70 \\
\hline \multirow[t]{5}{*}{23} & $05-15-97$ & 103 & 670 & 10 & 1 & 1.1 & $<1$ & 200 & 8 & 510 \\
\hline & $06-04-97$ & 91.7 & 540 & 6 & 1.2 & .9 & $<1$ & 11 & 8 & 310 \\
\hline & $08-26-97$ & .39 & 1,200 & 170 & 30 & 27 & $<1$ & 51 & 39 & 3,800 \\
\hline & $08-26-97^{1}$ & .39 & 1,200 & 170 & 30 & 27 & $<1$ & 52 & 39 & 3,800 \\
\hline & $10-07-97$ & 4.50 & 310 & 63 & 3.4 & 3 & $<1$ & 170 & 69 & 1,300 \\
\hline \multirow[t]{4}{*}{25} & $05-15-97$ & 27.3 & 600 & 4 & 2 & 2.1 & 1 & 31 & 14 & 390 \\
\hline & $06-02-97$ & 17.9 & 540 & 3 & 1.1 & 1.2 & $<1$ & 23 & 12 & 310 \\
\hline & $08-27-97$ & 1.74 & 210 & $<3$ & 1.8 & 1.6 & $<1$ & 17 & 7 & 200 \\
\hline & $10-08-97$ & 2.17 & 120 & $<3$ & 1.5 & 1.3 & $<1$ & 31 & 5 & 140 \\
\hline \multirow[t]{4}{*}{28} & $05-15-97$ & 135 & 680 & 17 & 1.3 & 1.3 & $<1$ & 42 & 11 & 530 \\
\hline & $06-04-97$ & 92.3 & 470 & 9 & 1.1 & .9 & $<1$ & 17 & 10 & 330 \\
\hline & $08-27-97$ & 2.22 & 120 & 30 & 2.8 & 2.7 & $<1$ & 17 & $<1$ & 210 \\
\hline & $10-08-97$ & 6.41 & 180 & 27 & 2.8 & 2.6 & $<1$ & 88 & 37 & 630 \\
\hline \multirow[t]{5}{*}{29} & $05-15-97$ & 2.56 & 380 & $<3$ & $<.1$ & $<.1$ & $<1$ & 14 & 1 & 390 \\
\hline & $05-15-97$ & 2.56 & 200 & $<3$ & $<.1$ & $<.1$ & $<1$ & 12 & 1 & 380 \\
\hline & $06-02-97$ & 2.45 & 150 & $<3$ & $<.1$ & $<.1$ & $<1$ & 13 & 3 & 370 \\
\hline & $08-27-97$ & 1.03 & $<100$ & $<3$ & $<.1$ & $<.1$ & $<1$ & 6 & $<1$ & 390 \\
\hline & $10-08-97$ & .45 & $<100$ & $<3$ & $<.1$ & $<.1$ & $<1$ & $<1$ & $<1$ & 240 \\
\hline \multirow[t]{4}{*}{31} & $05-16-97$ & 1.36 & 970 & $<3$ & .3 & $<.1$ & $<1$ & 14 & 3 & 680 \\
\hline & $06-02-97$ & 1.26 & 700 & $<3$ & $<.1$ & $<.1$ & $<1$ & 10 & 11 & 480 \\
\hline & $08-27-97$ & .10 & 290 & $<3$ & $<.1$ & $<.1$ & $<1$ & 7 & $<1$ & 320 \\
\hline & $10-08-97$ & .18 & $<100$ & $<3$ & $<.1$ & $<.1$ & $<1$ & 18 & $<1$ & 130 \\
\hline \multirow[t]{4}{*}{32} & $05-16-97$ & 28.6 & 590 & $<3$ & $<.1$ & $<.1$ & $<1$ & 21 & 7 & 630 \\
\hline & $06-02-97$ & 19.0 & 310 & $<3$ & $<.1$ & $<.1$ & $<1$ & 15 & 5 & 480 \\
\hline & $08-27-97$ & 1.25 & 240 & $<3$ & $<.1$ & $<.1$ & $<1$ & 10 & $<1$ & 1,500 \\
\hline & $10-08-97$ & 2.68 & 350 & $<3$ & $<.1$ & $<.1$ & $<1$ & 37 & $<1$ & 1,800 \\
\hline \multirow[t]{8}{*}{34} & $05-15-97$ & 177 & 680 & 17 & 1.1 & .8 & $<1$ & 51 & 6 & 630 \\
\hline & $05-15-97^{1,2}$ & 177 & 550 & -- & 1.0 & $<1$ & $<1$ & 12 & 9 & 530 \\
\hline & $06-05-97$ & 108 & 480 & 10 & 1.0 & .7 & $<1$ & 12 & 9 & 330 \\
\hline & $06-05-97^{1,2}$ & 108 & 240 & -- & $<1$ & $<1$ & $<1$ & 8 & 7 & 260 \\
\hline & $08-27-97$ & 5.20 & $<100$ & 19 & .9 & .7 & $<1$ & 10 & 2 & 260 \\
\hline & $08-27-97^{1}$ & 5.20 & $<100$ & 18 & .9 & .7 & $<1$ & 13 & $<1$ & 250 \\
\hline & $10-08-97$ & 8.10 & $<100$ & 19 & 1.3 & 1.1 & $<1$ & 46 & 14 & 430 \\
\hline & $10-08-97^{1}$ & 8.10 & $<100$ & 17 & 1.3 & 1.1 & $<1$ & 43 & 14 & 430 \\
\hline
\end{tabular}


Table 13. Concentrations of trace elements and suspended sediment in streams in the upperTenmile Creek watershed, Montana (Continued)

\begin{tabular}{|c|c|c|c|c|c|c|c|c|c|c|c|}
\hline $\begin{array}{c}\text { Lead, } \\
\text { total } \\
\text { rec. } \\
(\mu \mathrm{g} / \mathrm{L} \text { as } \\
\mathrm{Pb})\end{array}$ & $\begin{array}{c}\text { Lead, } \\
\text { dissolved } \\
(\mu \mathrm{g} / \mathrm{L} \text { as } \\
\mathrm{Pb})\end{array}$ & $\begin{array}{c}\text { Manga- } \\
\text { nese, } \\
\text { total } \\
\text { rec. } \\
(\mu \mathrm{g} / \mathrm{L} \text { as } \\
\text { Mn })\end{array}$ & $\begin{array}{c}\text { Mer- } \\
\text { cury, } \\
\text { total } \\
\text { rec. } \\
(\mu \mathrm{g} / \mathrm{L} \text { as } \\
\text { Hg) }\end{array}$ & $\begin{array}{l}\text { Nickel, } \\
\text { total } \\
\text { rec. } \\
(\mu \mathrm{g} / \mathrm{L} \text { as } \\
\mathrm{Ni})\end{array}$ & $\begin{array}{c}\text { Sele- } \\
\text { nium, } \\
\text { total } \\
\text { rec. } \\
(\mu \mathrm{g} / \mathrm{L} \\
\text { as Se) }\end{array}$ & $\begin{array}{c}\text { Silver, } \\
\text { total rec. } \\
(\mu \mathrm{g} / \mathrm{L} \text { as } \\
\text { Ag) }\end{array}$ & $\begin{array}{c}\text { Zinc, } \\
\text { total } \\
\text { rec. } \\
(\mu \mathrm{g} / \mathrm{L} \text { as } \\
\mathrm{Zn})\end{array}$ & $\begin{array}{c}\text { Zinc, } \\
\text { dissolved } \\
(\mu \mathrm{g} / \mathrm{L} \text { as } \\
\mathrm{Zn})\end{array}$ & $\begin{array}{c}\text { Sedi- } \\
\text { ment, } \\
\text { sus- } \\
\text { pended } \\
(\mathrm{mg} / \mathrm{L})\end{array}$ & $\begin{array}{c}\text { Sediment, } \\
\text { sus- } \\
\text { pended, } \\
\text { sieve } \\
\text { diameter } \\
<0.062 \mathrm{~mm} \\
\text { (percent) }\end{array}$ & $\begin{array}{c}\text { Site } \\
\text { number } \\
\text { (fig. 1) }\end{array}$ \\
\hline 10 & $<3$ & 15 & $<.6$ & $<20$ & -- & $<3$ & $<100$ & $<100$ & 6 & 91 & 20 \\
\hline 3 & $<3$ & 12 & $<.6$ & $<20$ & $<1$ & $<3$ & $<100$ & $<100$ & 3 & 90 & \\
\hline$<3$ & $<3$ & 34 & $<.6$ & $<20$ & -- & $<3$ & $<100$ & $<100$ & 3 & 85 & \\
\hline 6 & $<3$ & 64 & $<.6$ & $<20$ & $<1$ & $<3$ & $<100$ & $<100$ & 5 & 86 & \\
\hline 4 & $<3$ & 69 & $<.6$ & $<20$ & -- & $<3$ & 210 & $<100$ & 22 & 66 & 22 \\
\hline$<3$ & $<3$ & 16 & $<.6$ & $<20$ & $<1$ & $<3$ & 170 & 120 & 6 & 33 & \\
\hline$<3$ & $<3$ & 6 & $<.6$ & $<20$ & -- & $<3$ & 130 & 140 & 3 & 51 & \\
\hline 3 & $<3$ & 9 & $<.6$ & $<20$ & $<1$ & $<3$ & 150 & 130 & 2 & 64 & \\
\hline 16 & $<3$ & 70 & $<.6$ & $<20$ & -- & $<3$ & 160 & 160 & 31 & 50 & 23 \\
\hline 71 & $<3$ & 58 & $<.6$ & $<20$ & 1 & $<3$ & 160 & 140 & 7 & 77 & \\
\hline 18 & 5 & 1,100 & $<.6$ & $<20$ & -- & $<3$ & 3,100 & 3,000 & 12 & 96 & \\
\hline 19 & 4 & 1,100 & $<.6$ & $<20$ & -- & $<3$ & 3,100 & 3,200 & 12 & 92 & \\
\hline 8 & $<3$ & 190 & $<.6$ & $<20$ & $<1$ & $<3$ & 560 & 500 & 7 & 89 & \\
\hline 6 & $<3$ & 38 & $<.6$ & $<20$ & -- & $<3$ & 310 & 270 & 10 & 68 & 25 \\
\hline$<3$ & $<3$ & 33 & $<.6$ & $<20$ & $<1$ & $<3$ & 210 & 200 & 5 & 71 & \\
\hline$<3$ & $<3$ & 280 & $<.6$ & $<20$ & -- & $<3$ & 330 & 290 & 5 & 86 & \\
\hline 6 & $<3$ & 8 & $<.6$ & $<20$ & $<1$ & $<3$ & 340 & 290 & 7 & 77 & \\
\hline 13 & 7 & 60 & $<.6$ & $<20$ & -- & $<3$ & 210 & 180 & 20 & 61 & 28 \\
\hline$<3$ & $<3$ & 32 & $<.6$ & $<20$ & 1 & $<3$ & 170 & 170 & 9 & 66 & \\
\hline 8 & $<3$ & 53 & $<.6$ & $<20$ & -- & $<3$ & 550 & 540 & 12 & 59 & \\
\hline 6 & $<3$ & 110 & $<.6$ & $<20$ & $<1$ & $<3$ & 640 & 570 & 4 & 80 & \\
\hline 6 & $<3$ & 28 & $<.6$ & $<20$ & -- & $<3$ & $<100$ & $<100$ & 8 & 79 & 29 \\
\hline 4 & $<3$ & 26 & $<.6$ & $<20$ & -- & $<3$ & $<100$ & $<100$ & 7 & 76 & \\
\hline$<3$ & $<3$ & 29 & $<.6$ & $<20$ & $<1$ & $<3$ & $<100$ & 100 & 7 & 74 & \\
\hline$<3$ & $<3$ & 46 & $<.6$ & $<20$ & -- & $<3$ & $<100$ & $<100$ & 4 & 75 & \\
\hline$<3$ & $<3$ & 21 & $<.6$ & $<20$ & $<1$ & $<3$ & $<100$ & $<100$ & 56 & 26 & \\
\hline 8 & $<3$ & 31 & $<.6$ & $<20$ & -- & $<3$ & $<100$ & $<100$ & 22 & 76 & 31 \\
\hline$<3$ & $<3$ & 23 & $<.6$ & $<20$ & $<1$ & $<3$ & $<100$ & $<100$ & 18 & 76 & \\
\hline$<3$ & $<3$ & 34 & $<.6$ & $<20$ & -- & $<3$ & $<100$ & $<100$ & 15 & 81 & \\
\hline 4 & 4 & 15 & $<.6$ & $<20$ & $<1$ & $<3$ & $<100$ & $<100$ & 17 & 53 & \\
\hline 9 & $<3$ & 24 & $<.6$ & $<20$ & -- & $<3$ & $<100$ & $<100$ & 13 & 63 & 32 \\
\hline$<3$ & $<3$ & 26 & $<.6$ & $<20$ & $<1$ & 10 & $<100$ & $<100$ & 12 & 80 & \\
\hline$<3$ & $<3$ & 120 & $<.6$ & $<20$ & -- & $<3$ & 100 & $<100$ & -- & -. & \\
\hline 4 & $<3$ & 220 & $<.6$ & $<20$ & $<1$ & $<3$ & $<100$ & $<100$ & 21 & 42 & \\
\hline 12 & $<3$ & 59 & $<.6$ & $<20$ & -- & $<3$ & 180 & 120 & 34 & 43 & 34 \\
\hline 8 & $<1$ & 46 & $<.1$ & 1 & -- & $<1$ & 160 & 140 & -- & -. & \\
\hline 10 & $<3$ & 32 & $<.6$ & $<20$ & $<1$ & $<3$ & 140 & 130 & 6 & 83 & \\
\hline 3 & $<1$ & 25 & $<.1$ & 1 & -- & $<1$ & 140 & 140 & 7 & 68 & \\
\hline$<3$ & $<3$ & 15 & $<.6$ & $<20$ & -- & $<3$ & 160 & 140 & 3 & 86 & \\
\hline$<3$ & $<3$ & 12 & $<.6$ & $<20$ & -- & $<3$ & 160 & 160 & 4 & 81 & \\
\hline 3 & $<3$ & 33 & $<.6$ & $<20$ & $<1$ & $<3$ & 320 & 310 & 3 & 88 & \\
\hline 3 & $<3$ & 31 & $<.6$ & $<20$ & $<1$ & $<3$ & 310 & 290 & 3 & 69 & \\
\hline
\end{tabular}


Table 13. Concentrations of trace elements and suspended sediment in streams in the upperTenmile Creek watershed, Montana (Continued)

\begin{tabular}{|c|c|c|c|c|c|c|c|c|c|c|}
\hline $\begin{array}{c}\text { Site } \\
\text { number } \\
\text { (fig. 1) }\end{array}$ & Date & $\begin{array}{c}\text { Dis- } \\
\text { charge, } \\
\text { inst., } \\
\text { (cubic feet } \\
\text { per } \\
\text { second) }\end{array}$ & $\begin{array}{l}\text { Aluminum, } \\
\text { total rec. } \\
(\mu \mathrm{g} / \mathrm{L} \text { as } \mathrm{Al})\end{array}$ & $\begin{array}{c}\text { Arsenic, } \\
\text { total rec. } \\
(\mu \mathrm{g} / \mathrm{L} \text { as } \\
\text { As })\end{array}$ & $\begin{array}{l}\text { Cad- } \\
\text { mium, } \\
\text { total rec. } \\
(\mu \mathrm{g} / \mathrm{L} \text { as } \\
\text { Cd) }\end{array}$ & $\begin{array}{l}\text { Cad- } \\
\text { mium, } \\
\text { dissolved } \\
(\mu \mathrm{g} / \mathrm{L} \text { as } \\
\text { Cd })\end{array}$ & $\begin{array}{c}\text { Chro- } \\
\text { mium, } \\
\text { total rec. } \\
(\mu \mathrm{g} / \mathrm{L} \text { as } \\
\text { Cr })\end{array}$ & $\begin{array}{c}\text { Copper, } \\
\text { total rec. } \\
(\mu \mathrm{g} / \mathrm{L} \text { as } \\
\text { Cu })\end{array}$ & $\begin{array}{c}\text { Copper, } \\
\text { dissolved } \\
(\mu \mathrm{g} / \mathrm{L} \text { as } \\
\text { Cu })\end{array}$ & $\begin{array}{c}\text { Iron, } \\
\text { total rec. } \\
(\mu \mathrm{g} / \mathrm{L} \text { as } \\
\text { Fe })\end{array}$ \\
\hline \multicolumn{11}{|c|}{ BLANKS } \\
\hline \multirow[t]{8}{*}{--} & $05-16-97$ & -- & $<100$ & $<3$ & $<.1$ & $<.1$ & $<1$ & 3 & $<1$ & $<10$ \\
\hline & $06-05-97$ & -- & $<100$ & $<3$ & $<.1$ & $<.1$ & $<1$ & 1 & 1 & $<10$ \\
\hline & $08-27-97$ & -- & $<100$ & $<3$ & $<.1$ & $<.1$ & $<1$ & $<1$ & $<1$ & $<10$ \\
\hline & $10-09-97$ & -- & $<100$ & $<3$ & $<.1$ & -- & $<1$ & $<1$ & - & $<10$ \\
\hline & $10-09-97$ & -- & $<100$ & $<3$ & $<.1$ & -- & $<1$ & $<1$ & -- & $<10$ \\
\hline & $10-09-97$ & -- & $<100$ & $<3$ & $<.1$ & -- & $<1$ & $<1$ & -- & $<10$ \\
\hline & $10-09-97$ & -- & $<100$ & $<3$ & $<.1$ & -- & $<1$ & $<1$ & -- & $<10$ \\
\hline & $10-09-97$ & -- & $<100$ & $<3$ & $<.1$ & $<.1$ & $<1$ & $<1$ & $<1$ & $<10$ \\
\hline
\end{tabular}

${ }^{\top}$ Replicate sample.

${ }^{2}$ Replicate sample analyzed at USGS National Water Quality Laboratory. 
Table 13. Concentrations of trace elements and suspended sediment in streams in the upperTenmile Creek watershed, Montana (Continued)

\begin{tabular}{|c|c|c|c|c|c|c|c|c|c|c|c|}
\hline $\begin{array}{c}\text { Lead, } \\
\text { total } \\
\text { rec. } \\
(\mu \mathrm{g} / \mathrm{L} \text { as } \\
\text { Pb) }\end{array}$ & $\begin{array}{c}\text { Lead, } \\
\text { dissolved } \\
(\mu \mathrm{g} / \mathrm{L} \text { as } \\
\mathrm{Pb})\end{array}$ & $\begin{array}{l}\text { Manga- } \\
\text { nese, } \\
\text { total } \\
\text { rec. } \\
(\mu \mathrm{g} / \mathrm{L} \text { as } \\
\text { Mn })\end{array}$ & $\begin{array}{l}\text { Mer- } \\
\text { cury, } \\
\text { total } \\
\text { rec. } \\
(\mu \mathrm{g} / \mathrm{L} \text { as } \\
\text { Hg) }\end{array}$ & $\begin{array}{c}\text { Nickel, } \\
\text { total } \\
\text { rec. } \\
(\mu \mathrm{g} / \mathrm{L} \text { as } \\
\mathrm{Ni})\end{array}$ & $\begin{array}{l}\text { Sele- } \\
\text { nium, } \\
\text { total } \\
\text { rec. } \\
(\mu \mathrm{g} / \mathrm{L} \\
\text { as Se })\end{array}$ & $\begin{array}{c}\text { Silver, } \\
\text { total rec. } \\
(\mu \mathrm{g} / \mathrm{L} \text { as } \\
\text { Ag })\end{array}$ & $\begin{array}{c}\text { Zinc, } \\
\text { total } \\
\text { rec. } \\
(\mu \mathrm{g} / \mathrm{L} \text { as } \\
\mathrm{Zn})\end{array}$ & $\begin{array}{c}\text { Zinc, } \\
\text { dissolved } \\
(\mu \mathrm{g} / \mathrm{L} \text { as } \\
\mathrm{Zn})\end{array}$ & $\begin{array}{c}\text { Sedi- } \\
\text { ment, } \\
\text { sus- } \\
\text { pended } \\
\text { (mg/L) }\end{array}$ & $\begin{array}{l}\text { Sediment, } \\
\text { sus- } \\
\text { pended, } \\
\text { sieve } \\
\text { diameter } \\
<0.062 \mathrm{~mm} \\
\text { (percent) }\end{array}$ & $\begin{array}{c}\text { Site } \\
\text { number } \\
\text { (fig. 1) }\end{array}$ \\
\hline \multicolumn{12}{|c|}{ BLANKS } \\
\hline$<3$ & $<3$ & $<5$ & $<.6$ & $<20$ & -- & $<3$ & $<100$ & $<100$ & -- & .. & .- \\
\hline$<3$ & $<3$ & $<5$ & $<.6$ & $<20$ & $<1$ & $<3$ & $<100$ & $<100$ & -. & -. & \\
\hline$<3$ & $<3$ & $<5$ & $<.6$ & $<20$ & -- & $<3$ & 100 & $<100$ & -- & -- & \\
\hline$<3$ & -- & $<5$ & - & $<20$ & $<1$ & $<3$ & $<100$ & -- & -- & -- & \\
\hline$<3$ & -- & $<5$ & -- & $<20$ & $<1$ & $<3$ & $<100$ & -- & -- & -- & \\
\hline$<3$ & -- & $<5$ & -. & $<20$ & $<1$ & $<3$ & $<100$ & -. & -- & -- & \\
\hline$<3$ & -- & $<5$ & -- & $<20$ & $<1$ & $<3$ & 100 & -- & -- & -- & \\
\hline$<3$ & $<3$ & $<5$ & $<.6$ & $<20$ & $<1$ & $<3$ & $<100$ & $<100$ & -- & -- & \\
\hline
\end{tabular}


Table 14. Trace-element concentrations in bottom sediment from Chessman Reservoir and an adjacent wetland in the upper Tenmile Creek watershed, compared to concentrations in bottom sediment from Lake Helena, Montana

[Samples collected September 8, 1997. Analyzes conducted by U.S. Geological Survey on sediment fraction finer than 0.062 millimeter diameter. Symbol: <, less than]

\begin{tabular}{lcccccc}
\hline & \multicolumn{5}{c}{ Concentration, total in micrograms per gram of dry sample weight } \\
\cline { 2 - 6 } Trace element & \multicolumn{5}{c}{ Chessman Reservoir } \\
\cline { 2 - 6 } & Site R1 & Site R2A & Site R2B & Site R3 & Site R4 & Lake Helena ${ }^{1}$ \\
\hline Arsenic & 48 & 24 & 31 & 55 & 30 & $18-46$ \\
Cadmium & 1.7 & 1 & 1.8 & 1.9 & 1.3 & $<2-4$ \\
Chromium & 9.6 & 8 & 14.9 & 25.9 & 14.6 & $43-47$ \\
Copper & 162 & 264 & 617 & 219 & 228 & $47-82$ \\
Lead & 49 & 23 & 44 & 105 & 34 & $38-170$ \\
Zinc & 151 & 66 & 231 & 448 & 167 & $200-600$ \\
\hline
\end{tabular}

${ }^{1}$ Range of analyses from 3 sites (Kendy and others, 1998, p. 54) 
Table 15. Equations for calculating hardness-dependent aquatic-life criteria for trace elements

[Equations provide numerical standards in micrograms per liter $(\mu \mathrm{g} / \mathrm{L})$. Hardness used in equations is total hardness calculated from calcium and magnesium concentrations and expressed as milligrams per liter $(\mathrm{mg} / \mathrm{L})$ of $\mathrm{CaCO}_{3}$. For samples having hardness less than $25 \mathrm{mg} / \mathrm{L}$, Montana Department of Environmental Quality (1995) uses a hardness value of $25 \mathrm{mg} / \mathrm{L}$ for computing the standard. Symbol: --, no standard; e, base of natural logarithms, equal to 2.718]

\begin{tabular}{lll}
\hline \multirow{2}{*}{ Trace element } & \multicolumn{1}{c}{ Freshwater aquatic-life standard $\mathbf{1}$, in $\mu \mathbf{g} / \mathbf{L}$} \\
\cline { 2 - 3 } & \multicolumn{1}{c}{ Acute toxicity } & \multicolumn{1}{c}{ Chronic toxicity } \\
\hline Cadmium & $\mathrm{e}^{(1.128[\ln (\text { hardness) }]-3.828)}$ & $\mathrm{e}^{(0.7852[\ln (\text { hardness })]-3.490)}$ \\
Copper & $\mathrm{e}^{(0.9422[\ln (\text { hardness })]-1.464)}$ & $\mathrm{e}^{(0.8545[\ln (\text { hardness })]-1.465)}$ \\
Lead & $\mathrm{e}^{(1.273[\ln \text { (hardness)]-1.460) }}$ & $\mathrm{e}^{(1.273[\ln (\text { hardness) })-4.705)}$ \\
Nickel & $\mathrm{e}^{(0.8460[\ln \text { (hardness) })+3.3612)}$ & $\mathrm{e}^{(0.8460[\ln (\text { hardness })]+1.1645)}$ \\
Silver & $\mathrm{e}^{(1.72[\ln \text { (hardness)]-6.52) }}$ & -- \\
\hline
\end{tabular}

${ }^{1}$ U.S. Environmental Protection Agency (1986). 
Table 16. Calculated instantaneous loads of selected trace elements and suspended sediment in streams in the upper Tenmile Creek watershed, Montana

[Symbol: <, less than. Concentrations used to calculate loads are presented in table 13. For replicate samples, calculated loads are based on average concentrations for the replicate samples. Trace-element loads are total recoverable]

\begin{tabular}{|c|c|c|c|c|c|c|c|c|c|c|}
\hline Site no. & Date & \multicolumn{9}{|c|}{ Calculated instantaneous load for indicated constituent, in pounds per day } \\
\hline \multirow[t]{2}{*}{1} & $08 / 25 / 97$ & 0.53 & 0.29 & $<0.01$ & $<0.01$ & 0.03 & 0.29 & 0.02 & 0.04 & 11.4 \\
\hline & $10 / 06 / 97$ & .18 & $<.10$ & $<.01$ & $<.01$ & $<.01$ & .07 & $<.01$ & .01 & 2.92 \\
\hline \multirow[t]{4}{*}{3} & $05 / 14 / 97$ & 47.8 & 200 & $<.77$ & .08 & 2.8 & 120 & 1.5 & 9.6 & 7,490 \\
\hline & $06 / 03 / 97$ & 41.0 & 82 & $<.66$ & .04 & 4.2 & 38 & $<.66$ & 3.1 & 1,770 \\
\hline & $08 / 25 / 97$ & 1.67 & $<.90$ & $<.03$ & $<.01$ & .04 & .99 & $<.03$ & $<.04$ & 18.0 \\
\hline & $10 / 06 / 97$ & .91 & $<.49$ & $<.01$ & $<.01$ & $<.01$ & .39 & $<.01$ & $<.02$ & 9.83 \\
\hline 6 & $10 / 06 / 97$ & .80 & .65 & .01 & $<.01$ & .07 & .60 & $<.01$ & $<.02$ & 17.3 \\
\hline \multirow[t]{3}{*}{7} & $06 / 03 / 97$ & 26.5 & 46 & $<.43$ & .03 & 2.3 & 36 & .57 & 4.9 & 1,000 \\
\hline & $08 / 25 / 97$ & .91 & $<.49$ & $<.01$ & $<.01$ & .01 & 1.2 & $<.01$ & .13 & 9.83 \\
\hline & $10 / 06 / 97$ & .30 & $<.16$ & $<.01$ & $<.01$ & $<.01$ & .16 & $<.01$ & .02 & 3.24 \\
\hline 9 & $08 / 25 / 97$ & .26 & .29 & $<.01$ & $<.01$ & $<.01$ & .14 & $<.01$ & $<.01$ & 8.42 \\
\hline 10 & $05 / 14 / 97$ & 28.7 & 110 & $<.46$ & .06 & 4.5 & 170 & 1.1 & 23 & 10,800 \\
\hline \multirow[t]{4}{*}{11} & $05 / 16 / 97$ & 1.38 & 15 & 1.3 & .19 & 1.8 & 12 & 1.0 & 11 & 1,120 \\
\hline & $06 / 03 / 97$ & .92 & 12 & .05 & .15 & 2.1 & 3.1 & .26 & 8.9 & 34.8 \\
\hline & $08 / 25 / 97$ & .08 & .82 & .01 & .01 & .13 & .18 & .03 & .73 & .43 \\
\hline & $10 / 07 / 97$ & .10 & .92 & .01 & .02 & .15 & .23 & .04 & .86 & 1.62 \\
\hline \multirow[t]{3}{*}{12} & $06 / 03 / 97$ & 94.2 & 200 & $<1.5$ & .31 & 9.7 & 120 & $<1.5$ & 19 & 4,580 \\
\hline & $08 / 25 / 97$ & 4.11 & $<2.2$ & .18 & .04 & .22 & 3.1 & .16 & .22 & 244 \\
\hline & $10 / 07 / 97$ & 3.57 & 2.7 & .10 & .03 & .71 & 3.3 & .12 & 1.9 & 77.1 \\
\hline 13 & $05 / 14 / 97$ & 106 & 440 & 4.6 & .63 & 15 & 340 & 8.6 & 47 & 16,600 \\
\hline \multirow[t]{2}{*}{15} & $08 / 26 / 97$ & .11 & $<.06$ & .01 & $<.01$ & .09 & 1.8 & $<.01$ & .22 & 5.94 \\
\hline & $10 / 07 / 97$ & 3.37 & 2.5 & .09 & .01 & 7.8 & 13 & .07 & 1.6 & 127 \\
\hline \multirow[t]{4}{*}{18} & $05 / 16 / 97$ & 4.20 & 6.8 & .61 & .06 & 1.2 & 9.8 & .75 & 1.6 & 431 \\
\hline & $06 / 04 / 97$ & 2.16 & 2.2 & .27 & .07 & .57 & 3.7 & .15 & .87 & 117 \\
\hline & $08 / 26 / 97$ & .25 & $<.13$ & .01 & $<.01$ & .01 & .11 & .01 & .01 & 0 \\
\hline & $10 / 07 / 97$ & .32 & $<.17$ & .01 & $<.01$ & .01 & .05 & $<.01$ & .01 & 3.46 \\
\hline \multirow[t]{4}{*}{20} & $05 / 16 / 97$ & 10.1 & 16 & .55 & .01 & 1.4 & 11 & .55 & .82 & 327 \\
\hline & $06 / 04 / 97$ & 13.7 & 33 & .37 & .01 & 1.5 & 18 & .22 & .89 & 222 \\
\hline & $08 / 26 / 97$ & 2.16 & 1.4 & .05 & $<.01$ & 1.0 & 4.0 & $<.03$ & .40 & 35.0 \\
\hline & $10 / 07 / 97$ & 5.91 & 4.1 & .13 & .01 & 7.7 & 19 & .19 & 2.0 & 160 \\
\hline
\end{tabular}


Table 16. Calculated instantaneous loads of selected trace elements and suspended sediment in streams in the upper Tenmile Creek watershed, Montana (Continued)

\begin{tabular}{|c|c|c|c|c|c|c|c|c|c|c|}
\hline \multirow[b]{2}{*}{ Site no. } & \multirow[b]{2}{*}{ Date } & \multicolumn{9}{|c|}{ Calculated instantaneous load for indicated constituent, in pounds per day } \\
\hline & & $\begin{array}{l}\text { Discharge, } \\
\text { in cubic feet } \\
\text { per second }\end{array}$ & Aluminum & Arsenic & Cadmium & Copper & Iron & Lead & Manganese & $\begin{array}{c}\text { Suspended } \\
\text { sediment }\end{array}$ \\
\hline \multirow[t]{4}{*}{22} & $05 / 15 / 97$ & 5.81 & 27 & .44 & .06 & 1.4 & 13 & .13 & 2.2 & 690 \\
\hline & $06 / 04 / 97$ & 2.38 & 6.4 & .08 & .02 & .28 & 2.2 & $<.04$ & .21 & 77.1 \\
\hline & $08 / 26 / 97$ & .29 & .19 & .01 & $<.01$ & .03 & .09 & $<.01$ & .01 & 4.70 \\
\hline & $10 / 07 / 97$ & .31 & .20 & .01 & $<.01$ & .07 & .12 & $<.01$ & .02 & 3.35 \\
\hline \multirow[t]{4}{*}{23} & $05 / 15 / 97$ & 103 & 370 & 5.6 & .56 & 110 & 280 & 8.9 & 39 & 17,200 \\
\hline & $06 / 04 / 97$ & 91.7 & 270 & 3.0 & .59 & 5.4 & 150 & 35 & 29 & 3,470 \\
\hline & $08 / 26 / 97$ & .39 & 2.5 & .36 & .06 & .11 & 8.0 & .04 & 2.3 & 25.3 \\
\hline & $10 / 07 / 97$ & 4.50 & 7.5 & 1.5 & .08 & 4.1 & 32 & .19 & 4.6 & 170 \\
\hline \multirow[t]{4}{*}{25} & $05 / 15 / 97$ & 27.3 & 88 & .59 & .29 & 4.6 & 57 & .88 & 5.6 & 1,470 \\
\hline & $06 / 02 / 97$ & 17.9 & 52 & .29 & .11 & 2.2 & 30 & $<.29$ & 3.2 & 483 \\
\hline & $08 / 27 / 97$ & 1.74 & 2.0 & $<.03$ & .02 & .16 & 1.9 & $<.03$ & 2.6 & 47.0 \\
\hline & $10 / 08 / 97$ & 2.17 & 1.4 & $<.04$ & .02 & .36 & 1.6 & .07 & .09 & 82.0 \\
\hline \multirow[t]{4}{*}{28} & $05 / 15 / 97$ & 135 & 500 & 12 & .95 & 31 & 390 & 9.5 & 44 & 14,600 \\
\hline & $06 / 04 / 97$ & 92.3 & 230 & 4.5 & .55 & 8.5 & 160 & $<1.5$ & 16 & 4,490 \\
\hline & $08 / 27 / 97$ & 2.22 & 1.4 & .36 & .03 & .20 & 2.5 & .10 & .64 & 144 \\
\hline & $10 / 08 / 97$ & 6.41 & 6.2 & .93 & .10 & 3.0 & 22 & .21 & 3.7 & 138 \\
\hline \multirow[t]{4}{*}{29} & $05 / 15 / 97$ & 2.56 & 4.0 & $<.04$ & $<.01$ & .18 & 5.3 & .07 & .37 & 111 \\
\hline & $06 / 02 / 97$ & 2.45 & 2.0 & $<.04$ & $<.01$ & .17 & 4.9 & .04 & .38 & 92.6 \\
\hline & $08 / 27 / 97$ & 1.03 & $<.56$ & $<.02$ & $<.01$ & .03 & 2.2 & $<.02$ & .26 & 22.2 \\
\hline & $10 / 08 / 97$ & .45 & $<.24$ & $<.01$ & $<.01$ & $<.01$ & .58 & $<.01$ & .05 & 136 \\
\hline \multirow[t]{4}{*}{31} & $05 / 16 / 97$ & 1.36 & 7.1 & $<.02$ & $<.01$ & .10 & 5.0 & .06 & .23 & 162 \\
\hline & $06 / 02 / 97$ & 1.26 & 4.8 & $<.02$ & $<.01$ & .07 & 3.3 & $<.02$ & .16 & 122 \\
\hline & $08 / 27 / 97$ & .10 & .16 & $<.01$ & $<.01$ & $<.01$ & .17 & $<.01$ & .02 & 8.10 \\
\hline & $10 / 08 / 97$ & .18 & $<.10$ & $<.01$ & $<.01$ & .02 & .13 & $<.01$ & .01 & 16.5 \\
\hline \multirow[t]{4}{*}{32} & $05 / 16 / 97$ & 28.6 & 91 & $<.46$ & .02 & 3.2 & 97 & 1.4 & 3.7 & 2,010 \\
\hline & $06 / 02 / 97$ & 19.0 & 32 & $<.31$ & .01 & 1.5 & 49 & $<.31$ & 2.7 & 1,230 \\
\hline & $08 / 27 / 97$ & 1.25 & 1.6 & $<.02$ & $<.01$ & .07 & 10 & $<.02$ & .81 & 0 \\
\hline & $10 / 08 / 97$ & 2.68 & 5.1 & $<.04$ & $<.01$ & .54 & 26 & .06 & 3.2 & 304 \\
\hline \multirow[t]{4}{*}{34} & $05 / 15 / 97$ & 177 & 590 & 16 & 1.0 & 30 & 550 & 10 & 50 & 32,500 \\
\hline & $06 / 05 / 97$ & 108 & 210 & 5.8 & .58 & 5.8 & 170 & 4.1 & 16 & 3,500 \\
\hline & $08 / 27 / 97$ & 5.20 & $<2.8$ & .52 & .03 & .31 & 7.1 & $<.08$ & .38 & 98 \\
\hline & $10 / 08 / 97$ & 8.10 & $<4.4$ & .79 & .06 & 2.0 & 19 & $<.13$ & 1.4 & 131 \\
\hline
\end{tabular}


